\title{
Wintering range of western yellow wagtail Motacilla flava in Africa and Europe in a historical perspective
}

\author{
Flavio Ferlini
}

\begin{abstract}
Over the past few centuries, some subspecies of the western yellow wagtail Motacilla flava have shown changes in their reproductive ranges. The aim of this research is to verify if changes have occurred also in the wintering range of the species in Africa and Europe from 1848 to 2017. The data, collected through the consultation of over 840 bibliographic sources, 184 travel reports, 38 databases (including 25 relating to museum collections) and some website, shows an expansion of the wintering range to the north. The analysis is also extended to the single subspecies (flava, iberiae, cinereocapilla, flavissima, thunbergi, pygmaea, feldegg, beema, lutea, leucocephala). The factors that can affect the conservation of the species during wintering are examined and the oversummering range of Motacilla flava in sub-Saharan Africa is also discussed.
\end{abstract}

Keywords: Europe, Africa, Sahel, climate change, northward range expansion, farmland expansion, agrochemical impact, oversummering in sub-Saharan Africa

Riassunto - Areale di svernamento della cutrettola Motacilla flava in Africa ed Europa in una prospettiva storica.

Dal 1848 al 2017 l'area di svernamento della cutrettola Motacilla flava in Africa è rimasta sostanzialmente stabile, con una probabile riduzione quantitativa in South Africa, forse legata al complessivo declino della specie nell'area di riproduzione europea. Dalla metà degli anni 1980 l'areale di svernamento si è significativamente espanso verso nord occupando in Europa l'area con temperature medie in gennaio superiori a $0{ }^{\circ} \mathrm{C}$. L'ampliamento verso settentrione dell'area utilizzata per lo svernamento da parte della Cutrettola è coerente con l'analoga tendenza manifestata da altre specie migratrici trans-sahariane, soprattutto non-Passeriformi. L'attuale distribuzione della specie durante l'inverno boreale può essere così sintetizzata: nei Paesi sud occidentali d'Europa (Spagna, Portogallo e Italia) è scarsa, ma regolare; è invece presente in modo più occasionale e limitato in Grecia, nelle isole del Mediterraneo sud-orientale (Malta, Creta Cipro), in Europa occidentale (Francia, Svizzera, Austria, Germania, Olanda, Regno Unito) e in Scandinavia. In Africa settentrionale è presente in modo consistente in Morocco ed Egitto e più limitato invece in Algeria, Tunisia e Libia. Sverna in modo localmente abbondante dal Sahel fino alle aree umide del Botswana; regolare, ma scarsa, più a sud fino a Città del Capo e ancor più occasionale in Angola e Namibia. Presenze

Via Cantore 3, 27040 Castelletto di Branduzzo (Pavia), Italia. E-mail: flavio.ferlini@unipv.it

\section{(C) 2020 Flavio Ferlini}

Received: 25 October 2018

Accepted for publication: 30 July 2019

Online publication: 7 October 2020 sporadiche nelle isole dell'Oceano Indiano (Seychelles, Réunion, ecc.). Assente dalle zone africane prettamente desertiche. A livello di sottospecie nel periodo di studio si sono rilevate le seguenti variazioni: aumentata presenza della sottospecie flava in Egitto a partire dagli anni 1970; minore ampiezza dell'area di presenza di iberiae rispetto a quanto indicato in pasato, in particolare nell'Africa Occidentale la sottospecie resta confinata fra la costa dell'Atlantico e il meridiano $2^{\circ}$ Ovest anziché raggiungere il $14^{\circ}$ Est come precedentemente indicato; espansione di cinereocapilla verso occidente, con significative presenze numeriche in Senegal e Gambia; maggiore ampiezza dell'areale di flavissima nell'Africa Occidentale con possibili presenze anche in Nigeria e Cameroon (s'ipotizza per questa sottospecie la presenza di una rotta migratoria minoritaria che, in modo più intenso in primavera, passa attraverso il Mediterraneo centrale); crescente presenza di thunbergi nei Paesi che si affacciano sul Golfo di Guinea ed estensione delle presenze lungo la costa atlantica in Gambia, Senegal e, con individui isolati, anche Marocco; espansione verso Ovest della feldegg nella fascia sub-sahariana e, dall'inizio del XXI secolo, in Egitto lungo il Nilo; apparente aumento numerico di beema in Ethiopia. Non si sono invece riscontrate variazioni significative nelle distribuzioni di pygmaea, lutea e leucocephala. Nuovi dati suggeriscono un possibile incremento delle presenze di Motacilla flava nell'Africa sub-sahariana durante l'inverno australe (giugno-agosto) e, a partire dagli anni 1990 (limitatamente alla parte orientale del continente) l'espansione verso nord dell'ambito geografico interessato da questo fenomeno. Le quattro aree sub-sahariane identificate come prioritarie per la conservazione dei passeriformi paleartici sono perfettamente idonee anche per la specifica protezione della Cutrettola. Ai fini della conservazione della specie, particolare attenzione merita la relazione fra Cutrettola e agricoltura in Africa: l'incremento della frequenza della specie nelle aree coltivate, specialmente in quelle allagate o nelle risaie, è evidente. Dal 1970 al 2000 l'area agricola nell'Africa sub-sahariana è aumentata del $4 \%, 1$ 'impiego dei fertilizzanti è più che triplicato e l'importazione di pesticidi è più che quintuplicato. Soprattuto quest'ultimo aspetto è preoccupante considerando i molteplici effetti che i prodotti chimici impiegati in agricoltura possono avere sugli uccelli. Il più pericoloso sembra essere il Carbofuran che è ancora usato nelle risaie africane per contrastare la presenza di locuste e uccelli. Come documentato in Senegal, tra gli uccelli che muoiono avvelenati nelle risaie a causa dell'uso di Carbofuran c'è la Cutrettola. Il Carbofuran è anche usato intenzionalmente per avvelenare e catturare animali selvatici (inclusa la Cutrettola) utilizzati come cibo dalle popolazioni locali o impiegati per la medicina tradizionale. Anche nell'Europa occidentale l'utilizzo dei prodotti chimici in ambito agricolo durante la stagione riproduttiva può costituire un serio pericolo, soprattutto in considerazione degli elevati livelli quantitativi impiegati per unità di superficie.

Parole chiave: areale di svernamento, Europa, Africa, Sahel, cambiamento climatico, espansione verso nord, espansione agricola, impatto dei prodotti agrochimici, estivazione nell'Africa subsahariana 


\section{INTRODUCTION}

One of the creation myths of Ancient Egypt from the Pyramid Texts of the Old Kingdom (ca. 2400-2300 BC) tells of the western yellow wagtail Motacilla flava: the Benu bird, the oldest and self-created living creature. It gives an account of the first dawn: the shining Benu bird skimming over the desolate waters of Nun (the dark water of chaos) until it came to rest on the primeval mound (Benben, a pyramid shaped stone) (Pinch, 2002; Redford, 2002; Wilkinson, 2003). As it did so, it opened its beak and cried out through the eternal silence of Nun. This was the first sound. The world was filled with «that which it had not known»; the cry of the Benu bird «determined what is and is not to be». Thus, the western yellow wagtail, as a manifestation of the sun god Atum and his ability to regenerate, brought life and light to the world (Quirke, 2001; David, 2002; Allen, 2016). Starting from the Middle Kingdom, the Benu bird was no longer described in the form of a western yellow wagtail, but of a heron (Quirke, 2001; David, 2002; Allen, 2016).

The Pyramid Texts is the oldest written source that refers to the behavior of a bird; in fact, this myth probably originates from the observation of the western yellow wagtails as they flew low over water snatching insects from surface (Kishchinski, 1980) and then alighted on the first outcrops of silt and stones at the end of the flooding of the Nile in late September; after this, life manifests itself in all its forms where previously there was only dry land. The sense of regeneration of the species, from which the Greek myth of the Phoenix originated, could be related to the change in color in western yellow wagtail that the Egyptians, at that time of the year, noticed with the arrival of individuals of the migratory subspecies. The western yellow wagtail Motacilla flava, in fact, is a polytypic species which includes ten subspecies distributed as indicated in Tab. 1 (Alström \& Mild, 2005; Gill \& Donsker, 2017).

Similar to what is known, for example, for European pied flycatcher Ficedula hypoleuca (Chernetsov et al., 2008; Ouwehand et al., 2016) and willow warbler Phylloscopus trochilus (Chamberlain et al., 2000; Newton, 2008), during the boreal winter, all the subspecies of western yellow wagtail overwinter in Africa with a distribution that reflects, at first glance, their position in the Palearctic: the subspecies nesting in the East, in Asia, mainly overwinter in Easten Africa, and the subspecies nesting in the West, in Europe, mainly overwinter in Western Africa (Fig. 1). In reality, the subspecies in most of the African continent are mixed throughout the winter period, but follow some distribution patterns: the subspecies that nest further north, winter more to the south (leap-frog migration), and for the same subspecies, the males overwinter, on average, farther north than females (Curry-Lindahl, 1963; Wood, 1975; 1992; Bell, 1996; Alström et al., 2003; Rappolle, 2013).

Some studies have shown that the breeding ranges of some subspecies have undergone significant changes over time. Particularly, the ashy-headed yellow wagtail Motacilla flava cinereocapilla and the black-headed yellow wagtail Motacilla flava feldegg have shown a clear tendency to expand their breeding ranges northwards,

Tab. 1 - Breeding and wintering ranges of western yellow wagtail subspecies / Areale riproduttivo e di svernamento delle sottospecie della cutrettola (source / fonte: Alström \& Mild, 2005; Gill \& Donsker, 2017).

\begin{tabular}{|l|l|l|l|}
\hline Scientific Name & Authority & Breeding Range & Wintering Range \\
\hline M.f. flavissima & (Blyth, 1834) & Britain and coastal Europe & Africa \\
\hline M.f. flava & Linnaeus, 1758 & North and Central Europe to the Ural Mts. & Africa \\
\hline M.f. thunbergi & Billberg, 1828 & North Europe to Northwest Siberia & $\begin{array}{l}\text { Africa and South, Southeast } \\
\text { Asia }\end{array}$ \\
\hline M.f. iberiae & Hartert, 1921 & $\begin{array}{l}\text { Iberian Peninsula, Southwest France and } \\
\text { Northwest Africa }\end{array}$ & West and Northcentral Africa \\
\hline M.f. cinereocapilla & Savi, 1831 & $\begin{array}{l}\text { Italy, Sicily, Corsica, Sardinia and } \\
\text { Slovenia }\end{array}$ & Central Africa \\
\hline M.f. pygmaea & (Brehm, 1854) & Egypt & Egypt \\
\hline M.f. feldegg & Michahelles, 1830 & $\begin{array}{l}\text { Balkans and Turkey to Iran and } \\
\text { Afghanistan }\end{array}$ & $\begin{array}{l}\text { South Asia, Northeast, } \\
\text { Central Africa }\end{array}$ \\
\hline M.f. beema & (Sykes, 1832) & $\begin{array}{l}\text { Southwest Siberia and Northeast } \\
\text { Kazakhstan to West Himalayas }\end{array}$ & India, Arabia and East Africa \\
\hline M.f. lutea & (Gmelin, 1774) & $\begin{array}{l}\text { Southwest Russia to Northwest and } \\
\text { Northcentral Kazakhstan }\end{array}$ & Africa and India \\
\hline M.f. leucocephala & (Przewalski, 1887) & $\begin{array}{l}\text { Northwest Mongolia, Northwest China } \\
\text { and Southcentral Siberia }\end{array}$ & India and East Africa \\
\hline
\end{tabular}




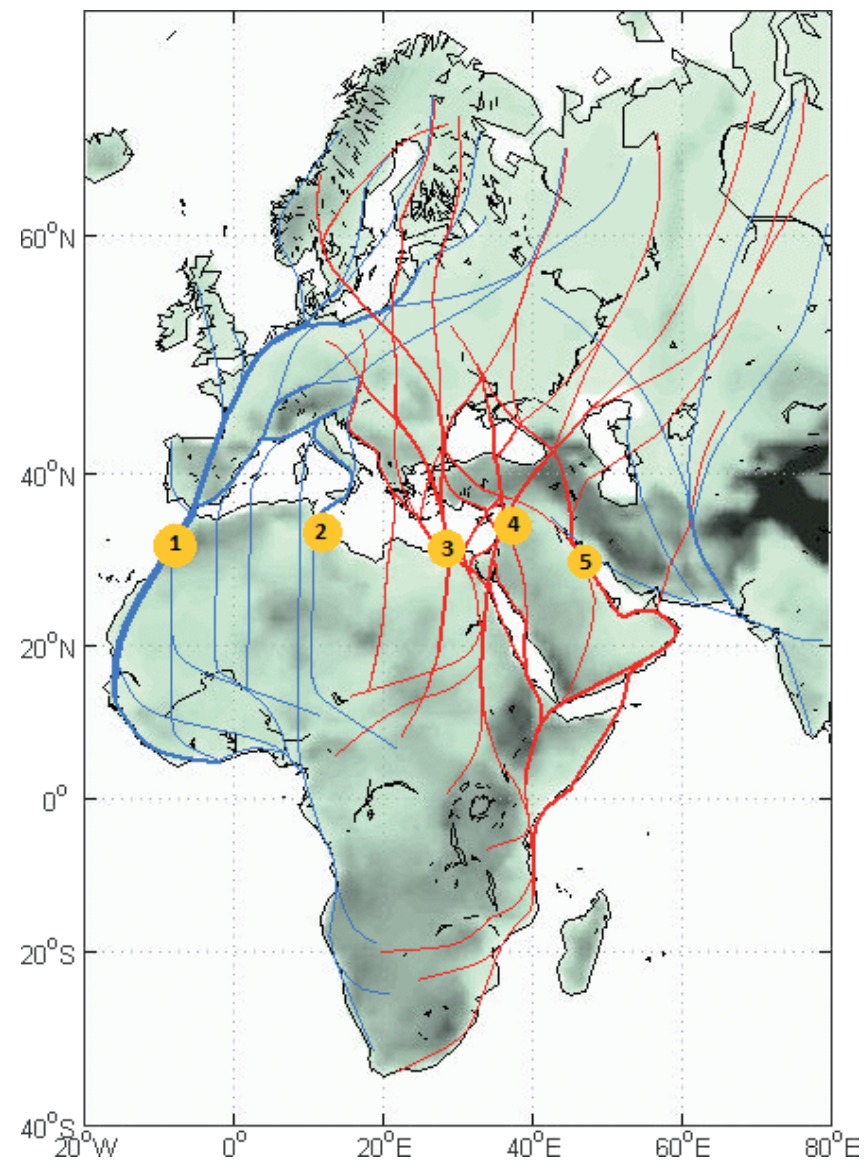

Fig. 1 - Bird migration routes in Europe, Africa, and Western Asia. / Rotte migratorie degli uccelli in Europa, Africa e Asia Occidentale. 1) Scandinavian-Iberian route (Western European) / rotta ScandinavoIberica (Europa Occidentale); 2) Central-Mediterranean route / rotta Centro-Mediterranea, 3) Balkan route / rotta Balcanica; 4) EasternEuropean route / rotta dell'Europa Orientale; 5) Caspian route / rotta Caspica. (Source / fonte: SE European Bird Migration Network, www. seen-net.eu).

with an accentuation of the phenomenon during the second half of the $20^{\text {th }}$ century (Ferlini, 2015; 2016). These expansions were probably favored by climate change (Ferlini, 2015; 2016).

The first aim of this study was to verify whether, as in the case of breeding ranges, changes have also occurred in wintering ranges of the species and subspecies, taking into account Africa and Europe from 1848 to 2017. Ornithological books and articles provide distribution maps regarding the breeding ranges of the species (Cramp, 1988; del Hoyo et al., 2004; Tyler \& Christie, 2017) or also of the subspecies (Dementiev \& Gladkov, 1954; Cova, 1969; Bernis, 1970; Ödeen, 2001; Alström et al., 2003; Golovatin \& Sokolov, 2017), while wintering ranges are recorded by general maps (Cramp, 1988; Alström et al., 2003; del Hoyo et al., 2004), including, with particular reference to Africa, continental (Keith et al., 1992; Walther et al., 2010) or regional maps (e.g. Harrison et al., 1997; Parker, 1999; Stevenson \& Fanshawe, 2002; Sinclair et al., 2005; Hockey et al., 2005; Sinclair \& Davidson, 2006; Ash \& Atkins, 2009; Redman et al., 2009; Borrow \& Demey,
2011), that include species information and indications about the distribution or presence of the subspecies only in textual terms. The only exception is the article by Grant $\&$ Mackworth-Praed (1952) that provide indicative maps of the wintering range for every subspecies.

The second aim of this study was to provide current maps of the wintering ranges of the species and subspecies in Africa and Europe.

\section{MATERIALS AND METHODS}

The present study is based on data obtained from the consultation of bibliographic sources, travel reports, databases (including 25 relating to museum collections) and some website. However, given the impossibility of consulting all the reports published during the period under study, the data presented here should not be considered exhaustive; nevertheless, they are sufficient to obtain an understanding of the changes that have occurred, as well as the current situation and trends.

The first useful information dates back to 1848 , since scientific publications from previous years do not mention the western yellow wagtail (Le Vaillant, 1799) or only refer to it in very general terms (Rüppell, 1845; Jardine, 1848-1852).

To try to give a quantitative indication of the distribution of the species in winter, transposition on distribution maps is made using colours according to the meanings below. The number of individuals is referred to as the maximum number of birds observed in each location. Obviously, these quantitative estimates are purely indicative given the different methodologies used by the various ornithologists to quantify the observed birds.

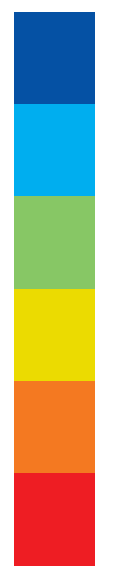

Single individual or presence without quantitative indication

2-10 individuals

11-100 individuals

101-1,000 individuals

$1,001-10,000$ individuals

Over 10,000 individuals

I considered winter data only observations recorded in December and January, because the subspecies composition of birds observed during migrations are not representative of wintering birds. I made exceptions to this principle only for periods or areas with limited availability of information and for rare subspecies (e.g. Motacilla flava leucocephala).

The findings of this study have been separated into four different time periods: 1848-1900, 1901-1945, 19461980, and 1981-2017.

Moreover, for the sake of simplicity, I divided the study area (Africa and Europe) into six geographical sub-areas: 
- Southern Africa: Botswana, Lesotho, Namibia, South Africa, and Swaziland.

- Eastern Africa: Burundi, Comoros, Djibouti, Eritrea, Ethiopia, Kenya, Madagascar, Malawi, Mauritius, Mayotte, Mozambique, Réunion, Rwanda, Seychelles, Somalia, South Sudan, Uganda, United Republic of Tanzania, Zambia, and Zimbabwe.

- Middle Africa: Angola, Cameroon, Central African Republic, Chad, Congo, Democratic Republic of Congo, Equatorial Guinea, Gabon, and São Tomé and Príncipe.

- Western Africa: Bénin, Burkina Faso, Cape Verde, Ivory Coast, Gambia, Ghana, Guinea, Guinea-Bissau, Liberia, Mali, Mauritania, Niger, Nigeria, Saint Helena, Ascension and Tristan da Cunha, Senegal, Sierra Leone, and Togo.

- Northern Africa: Algeria, Canary Islands, Egypt, Libya, Morocco, Sudan, Tunisia.

- Europe.

\section{RESULTS AND DISCUSSION}

Additional Supporting Information containing detailed results for the different geographical areas may be found online for this article.

\section{Wintering range of Motacilla flava in Africa (Plate 1)}

The distribution of the western yellow wagtail, here understood as species, does not seem to undergo large variations in Africa during the 170 years from 1848 to 2017 and remains mainly concentrated between the two tropics and using the same environments: lake shores, riversides, marshes, savannas, and cultivated fields often associated with grazing cattle, zebras, and antelopes, as already reported by various authors (Keith et al., 1992; Bell, 2006; Forget, 2010). Curry-Lindahl (1964) pointed out in the 1960 s that:

«... in the African tropics this species has a much wider ecological range than on the Palaearctic breeding grounds. ... In Africa, however, the Yellow Wagtail occurs in great numbers also in habitats that do not exist in Europe, for example, banana plantations at various altitudes, and rather arid savannas, where it associates with herds of elephants, buffaloes or various antelopes. Large banana plantations form a type of forest, the soil below the enormous leaves being almost always shaded and bare, for only very poor vegetation can, or is allowed to, grow there. In this dark world Yellow Wagtails may periodically be extremely common. I have also found them on small islands, where they run around basking crocodiles. The most unusual habitat beside that on Mount Nimba was in Lake Mwadingusha in the Katanga, where, in February 1963 , the birds used to perch on the dense aquatic vegetation of floating islands out in the open lake, far away from the terrestrial habitats».

An example of what was stated by Curry-Lindahl (1964) is the case of the subspecies thunbergi and beema. They are sympatric in European Russia and Western Siberia, however there are strong indications for segregated breeding: thunbergi occurred in bogs as a breeding bird and beema was dominantly found breeding in floodplain meadows (van Oosten \& Emtsev, 2013). This separation ceases when the two subspecies reach the African wintering areas where they share the same environments (e.g. shores of lakes and lagoons).

Compared to the past, the only novelty element that has emerged over the last few decades seems to be the growing use of cultivated fields (Bell, 2006), probably due to the more intensive use of irrigation techniques: in recent decades irrigated land is increasing in Africa at the rate of $0.88 \%$ per year $(F A O, 2016)$. The total area equipped for irrigation in Africa is 13.5 million hectares of which 11.5 million ha are actually under irrigation (Siebert \& Frenken, 2014). The regions with the highest density of irrigated land are located mainly in Northern Africa in the Nile Basin (Egypt, Sudan) and in the Mediterranean countries (Libya, Tunisia, Algeria, Morocco). The countries with the largest amount of irrigated areas are Egypt (3.6 million ha), Sudan (1.8 million ha), South Africa (1.7 million ha), and Morocco (1.5 million ha) (Siebert $\&$ Frenken, 2014). All of these countries face arid climate conditions. In Madagascar, where it is more humid, rice is cultivated on about 1.5 million ha of irrigated land (Siebert \& Frenken, 2014; Ricepedia.org, 2017).

With regard to the distribution of the abundance of Motacilla flava in the African continent, the collected data suggest some changes that have occurred over time, which must however be interpreted with caution due to the different contexts in which they were acquired and the uneven methodologies used:

- During the first years of the study period, some areas of the African continent still had to be explored. In particular, it is important to mention that Heinrich Barth, starting from Tripoli, crossed the entire Sahara and explored Lake Chad, then reached Timbuktu, and from there he returned to Tripoli between 1849 and 1855; Richard Burton discovered Lake Tanganyika in 1858; John Speke discovered Lake Victoria and the rapids with which the lake flows into the River Nile in 1862; David Livingstone, starting from Cape Town, traveled throughout Southern Africa, discovering Lake Ngami (1849), the upper Zambezi (1854), Lake Malawi (also known as Lake Nyasa) (1858), and the upper Congo (1869).

- Over time the number of ornithologists or birdwatchers who have visited Africa has progressively increased, and it is therefore quite natural that the mass of information available has increased, making the intensity of data collection in different periods not directly comparable.

- In expressing the presence of the species in the various geographical areas, the authors have often used highly subjective qualitative terms (e.g. scarce, common, abundant) which makes the comparison of data uncertain.

Even with the criticalities described above, I want to provide an interpretation of the changes over time, as perceived by the data collected.

In the extreme southern part of Africa, the presence of the western yellow wagtail had always been regular, but relatively scarce and probably in a tendential numerical regression in the northern regions of South Africa. In 
Plate 1 - Wintering range of / Areale di svernamento di Motacilla flava.

Single ind. 2-10 ind. $11-100$ ind. $101-1,000$ ind. $1,001-10,000$ ind.

Over 10,000 ind.

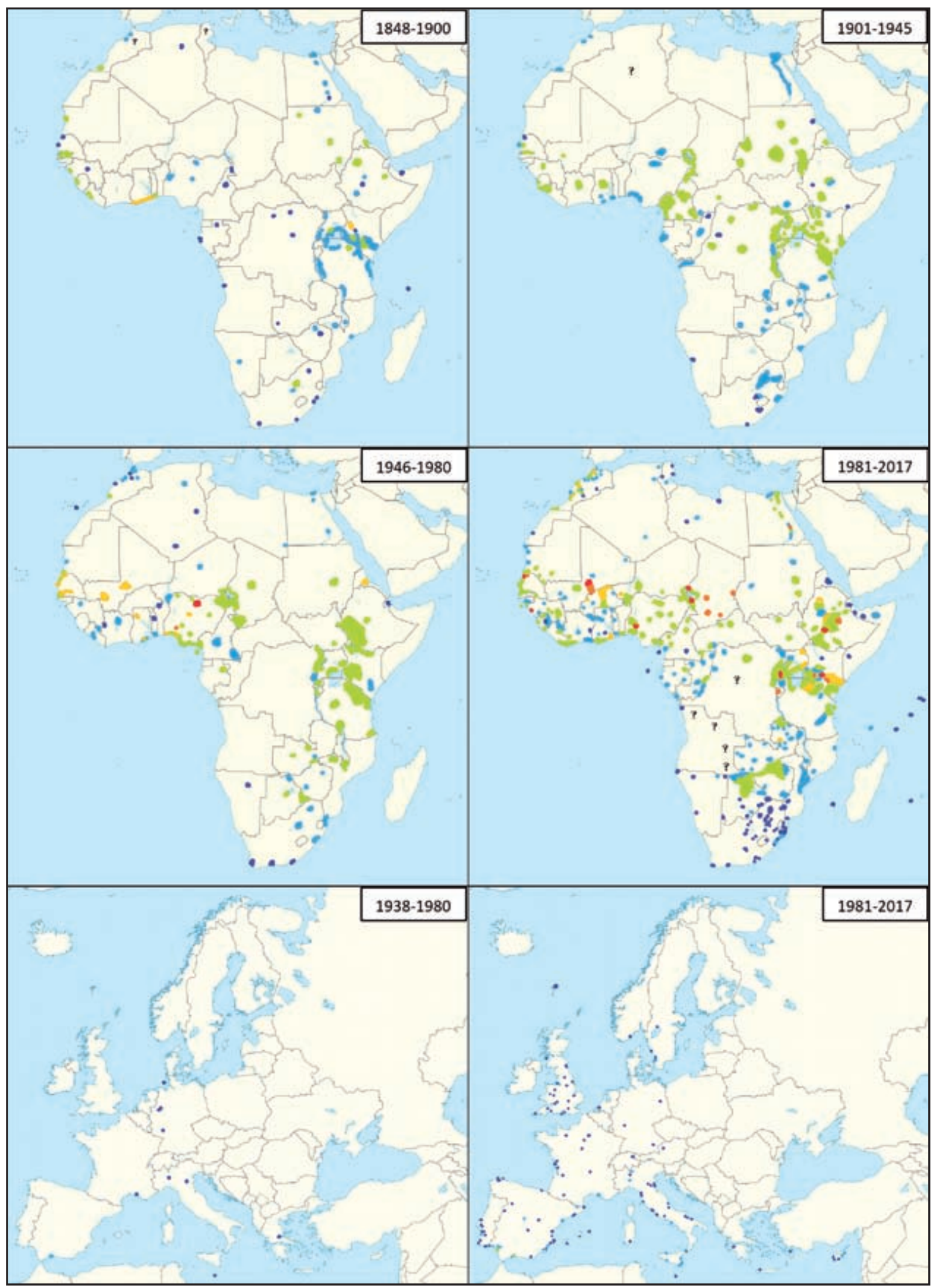


fact, while Ayres (1871) defined the species common in Transvaal, as early as the first decades of the $20^{\text {th }}$ century, western yellow wagtail was considered only a regular visitor with discontinuous distribution (Roberts, 1911; Haagner, 1912; Haagner \& Ivy, 1923; Meinertzhagen, 1921; Austin, 1942). In the following decades, while increasing data has been available concerning small groups or, more commonly, isolated individuals, I did not find other studies in which the species was defined common, with the sole exception of the Pilanesberg National Park where recently it was judged fairly common (Mankwe Wildlife Reserve, 2014). The hypothesis that there has been a progressive decrease in the number of individuals reaching the South African regions is confirmed for the Transvaal by Tarboton et al. (1987), which in the 1980s already reported a decrease of the species during the last century. Both in the period 1946-1980 and in the following one until 2017, the most southern area where the species was common is constituted by the Okavango and Zambezi river basins and, even further south, by the wetlands of the Central District of Botswana (Smithers, 1964; Clancey, 1966; Sinclair, 1994; Harrison et al., 1997; Carruthers, 2000; Mundy, 2000; Newman, 2002; 2003; Sinclair et al., 2002; 2005; Hockey et al., 2005; Sinclair \& Davidson, 2006; Gall, 2017; Grant \& Marks, 2017; Orrell \& Hollowell, 2017).

Apparently, the species has never been observed in the area that includes Cape Plateau (South Africa), Northern Cape Province (South Africa), the northern part of Western Cape Province (South Africa), Karas Region (Namibia), Kalahari Desert, and Namib Desert. For this area, the limiting factor is certainly the arid or semi-arid climate, unsuitable for hosting the species.

In Eastern Africa steadily over the past 170 years, there is a progressive increase in the number of wintering individuals going up, from Mozambique to the north, the East African Rift and the surrounding territories. In particular, the species has high concentrations along the lakes and the craters of the Eastern Rift Valley (including the Main Ethiopian Rift), the Western Rift Valley, and Lake Victoria. This could also be related to the increase in cultivated areas of Eastern Africa passed from 11.5 million ha in 1850 to 111.3 million ha in 2016 (Goldewijk, 2001; Xiong et al., 2017). The species is also reported at high altitudes: in the Central Region of Malawi at 1,500-1,700 m a.s.l. (Benson, 1940), on the slopes of Mount Kilimanjaro at about 2,250 $\mathrm{m}$ a.s.1. (Cordeiro, 1994), on the Kinangop Plateau at 2,400-3,000 $\mathrm{m}$ a.s.1., in the Trans-Mara Forest (Narok County) at about 2,100-2,400 m a.s.l. (Bennun, 1991) and Mount Kahuzi and the Virunga volcanoes at altitudes between 2,100-2,600 $\mathrm{m}$ a.s.1. (Curry-Lindahl, 1965).

With regard to the Malagasy Region, the total absence of western yellow wagtail in Madagascar is surprising considering: the great increase in arable land on the island (from 1.9 million ha in 1961 to 3.5 million ha in 2013), the considerable area cultivated with rice (from 0.8 million ha in 1961 to 1.5 million ha in 2014) (Ricepedia.org, 2017), and the repetition of observations (even numerically scarce) in the surrounding islands. The presence of the species in the Malagasy region is attributed to birds that detach themselves from the African continent heading towards east (flava, feldegg, beema, and lutea are, in fact, the subspecies present in that part of the African coast). Considering that the Seychelles archipelago is about $1,500 \mathrm{~km}$ from the coast of Eastern Africa, the effort required by the western yellow wagtails to reach it is comparable to that required for the Sahara overflight (width $1,500-2,000 \mathrm{~km}$ ). The total absence from Madagascar is even less plausible after the reporting of a specimen on Réunion in February 2017 (Riethmuller, 2017) as Madagascar is physically interposed between the African coast and this island. Réunion is about $750 \mathrm{~km}$ from Madagascar and over 2,000 km from the nearest mainland coast; it seems unlikely that the bird that reached Réunion did not stop in Madagascar before, since it is unlikely that the specimen arrived directly from the island closer on which the species has already been observed (Providence) with a flight of over 1,300 km. Areas of Madagascar potentially suitable for hosting the species are those cultivated with rice distributed in six zones of the island: the north, northwest, and central-western regions; the central part of the Malagasy highlands; the east; and the central-eastern part, including Lake Alaotra with its swampy areas, plains, and valleys.

On the west coast of the African continent, detailed data concerning Angola are extremely scarce over the whole period considered; this probably shows a very limited presence of the species that appears most likely in the south and along the coast (Mills \& Melo, 2013), as well as in the northern and eastern regions. Data relating to Democratic Republic of Congo indicate, over time, a persistent and significant presence of the species in the eastern part of the country and, in any case, a diffusion in the remaining part of the country that the maps, in each period, probably underestimate. In fact, several authors over the course of time have insisted that the species (especially the spp. flava and thunbergi) is common and widespread in all environmentally suitable areas (Chapin, 1953; Pedersen, 2009). In the remaining countries of Middle Africa, despite limited data availability for the period 1945-1980, there seems to be a good presence of the species everywhere, with points of particular concentration in some environments suitable for night roosts (for example around Lake Chad, to other lake basins and also in the rice fields of Southern Chad). Also in this part of the continent, the western yellow wagtail is present in mountain areas, in fact in Cameroon it is common on Mount Oku (Northwest Province) between 2,200 and 2,800 $\mathrm{m}$ a.s.l. (Fotso, 2001), and on Mount Cameroon (Southwest Province) at about 1,400 m a.s.l. (Grimes, 1971).

In the area immediately south of the Sahara, the western yellow wagtail is currently widely distributed and quite common with points of considerable concentration especially in Nigeria, Mali, and Senegal, even in mountain areas (e.g. Mambilla Plateau at 1,500-2,000 m a.s.l.; Hall, 1976; 1977). This situation confirms both what emerges from the maps of the less recent periods and what has been highlighted in the past by numerous studies. In particular, the importance was emphasized, both for Motacilla flava and other paleartic species, of humid environments constituting the Nile System between the White and Blue 
Niles from Khartoum south to Malakal and Roseires, respectively (Hogg et al., 1984), the Lake Chad basin (Salvan, 1967; 1969a; 1969b; 1969c), the inundation zone of the Upper Niger (Curry \& Sayer, 1979), and the Senegal River basin (Morel, 1973). The importance of these wetlands has recently been reaffirmed by several authors, who have estimated the presence of about 1,000,000 western yellow wagtails in winter in the inundation zone of the Upper Niger and around 500,000 others in the surrounding green areas (Zwarts et al., 2012), around 320,000 individuals in the $700 \mathrm{~km}^{2}$ of rice fields in Mali (Zwarts et al., 2012), around 500,000 specimens in the Senegal delta (Zwarts et al., 2012), and around 268,000 individuals in the $1,120 \mathrm{~km} 2$ rice fields in Senegambia, Guinea-Bissau, and Guinea (Bos et al., 2006). The highest densities were found in rice fields and wetlands with less than $80 \mathrm{~cm}$ of water. In general, dry areas have lower densities unless animals are present: in this case the density can be up to five times higher than identical habitats without livestock (Zwarts et al., 2012).

In relation to Northern Africa, in Egypt, due to the substantial sedentary nature of the pygmaea subspecies, the regular presence of the species along the River Nile and in the area of its Delta (globaly the most extensive oasis on Earth!) is confirmed throughout the investigation period. In Lybia, Tunisia, and Algeria, the situation is uncertain until at least 1945 , followed by sporadic reports in the period 1946-1980 and therefore an apparent increase in presences, especially in Tunisia. However, this trend must be considered cautiously given the probable increase in observers and the resulting greater availability of data. Similar attention must be paid to the situation in Morocco, where, however, the progressive increase in winter presences, both in terms of locations frequented by the species and in the number of birds present, as well as the presence of new subspecies never before reported in winter, indicates an actual change taking place. Numerically, the presences are more consistent along the Atlantic coast, but the species has also occupied internal areas with suitable environments. The limited availability of suitable environments seems to be the limiting factor for the wintering of the western yellow wagtail along the Mediterranean coast (Franchimount, pers. com.).

\section{African climatic conditions}

In consideration of the vastness of Africa, it is difficult to identify specific factors that correlate the distribution over time of the western yellow wagtail in wintering areas with environmental/climatic conditions and, above all, with the changes that have occurred. However, it is worthwhile to describe in general terms the climatic changes that have occurred during the study period, summarizing what is reported in the detailed studies by Nicholson (1994; 1998a; 1998b; 1999; 2001) on the subject. Particular emphasis is placed on precipitation trends as it has proved to be the factor of greatest impact on the environment (Chipanshiaet al., 1999; Betser, 2005).

With the exception of South Africa and the Mediterranean area, currently most of the African continent has a tropical climate with rains that vary quantitatively along a pronounced gradient: from $1 \mathrm{~mm} / \mathrm{year}$ in some areas of the Sahara to $5,000 \mathrm{~mm} /$ year in equatorial areas. Temperatures are normally high with modest variations in average values throughout the year (south of the Sahara remains between 6 and $10^{\circ} \mathrm{C}$ ), but day-night temperature variations are greater (as much as $10-15^{\circ} \mathrm{C}$, even more in the deserts).

After a period of strong and anomalous aridity during the $1820 \mathrm{~s}$ and $1830 \mathrm{~s}$, in the mid- $19^{\text {th }}$ century, most of the African lakes recovered and by the end of the $19^{\text {th }}$ century, most achieved very high stands, often exceeding any levels reached during the next century. From 1895 to the first decade of the $20^{\text {th }}$ century, a new strong decline occurred in rainfall in the global tropics with arid conditions similar to those of the previous century, although less accentuated in equatorial Eastern Africa and in the temperate extremes of the north and south coasts of Africa. Good conditions returned during the 1920s and 1930s in Western Africa, but dry conditions persisted in Southern Africa. In the 1940s, there was again widespread drought, particularly in Western Africa. More extreme fluctuations occurred in the latter half of the $20^{\text {th }}$ century. In the $1950 \mathrm{~s}$, rainfall and river flow increased markedly in the semiarid regions of Northern and Southern Africa. In the early 1960 s, rainfall increased dramatically throughout most of the equatorial region determining a significant increase in the level of Rift Valley lakes. In the late 1960s, a dry phase began that lasted for almost 30 years, followed by a period characterized by greater rainfall. Even with the fluctuations mentioned above, at the continental level the near surface temperatures increased by about $0.5{ }^{\circ} \mathrm{C}$ or more during the last 50-100 years with minimum temperatures warming more rapidly than maximum temperatures (Stern et al., 2011; Funk et al., 2012; Nicholson et al., 2013; Niang et al., 2014).

In recent times, with regard to the species, the greatest impact occurred during the last phase of widespread aridity in the 1970s as a result of obvious desertification phenomena that affected both wintering areas and territories crossed during migrations. In particular, the area in which the negative effect on the western yellow wagtail was most evident is that of the Sahel. This region lying between $12^{\circ} \mathrm{N}$ and $20^{\circ} \mathrm{N}$ longitude, covering the semiarid and arid climate zones south of the Sahara (Trémolières, 2010). The Sahel region represents a transition zone between the Saharan desert and tropical Africa; it covers all or parts of 12 countries from the Atlantic Ocean to the Red Sea: Senegal, Gambia, Mauritania, Mali, Burkina Faso, Niger, Nigeria, Chad, Sudan, Ethiopia, Eritrea, and Djibouti (Trémolières, 2010). The dominant feature of the climate of this region is the West African Monsoon (WAM) system, which is a recurrent low latitude large-scale circulation pattern arising from the meridional boundary layer gradient of dry and moist static energy between the warm sub-Saharan continent and the tropical Atlantic Ocean; the WAM system develops from April to October bringing the Inter-Tropical Convergence Zone (ITCZ) and associated rainfall maxima to their northernmost location in August (Buontempo, 2010). Then there is a long drought period from November to March. Rainfall decreases towards the north, and the Sahel turns 
into the Sahara Desert. Over the last half century, a large proportion of the Sahel has became a barren land resulting in the deterioration of the soil and water resources.

Between 1950 and 1965 there washigher rainfall, followed by dryer conditions culminating in 1984, the driest year in the last 70 years (Biasutti et al., 2008; Greene et $a l ., 2009)$. The effects of the severe water crisis that occurred in the Sahel can be easily understood by looking at Fig. 2 showing the dramatic decrease in Lake Chad's surface area over the last 54 years. The water level is largely controlled by the inflow from rivers, notably the River Chari from the south and, seasonally, the River Komodugu-Yobe from the northwest. Until 1973, the lake, although reduced in size, was still a single body of water, but by 1976 it had clearly separated into two areas: the northern basin and the southern basin, divided by a shallow sill called the Great Barrier. Throughout the 1970s, water disappeared from the northern basin. By the 1980s, the lake area reached a low of just $300 \mathrm{~km}^{2}$ (down from 22,000 km²) (Hansen, 2017).

Since 1985, an increase in rainfall has been observed in the Sahel, which until now has been barely sufficient to compensate for the massive water withdrawal from Lake Chad for irrigation. However, precipitation has caused the northward movement of the $300 \mathrm{~mm}$ isohyet, with an average progression of $9.4 \mathrm{~km} /$ year $(300 \mathrm{~mm}$ of annual rainfall is approximately what is needed for rainfed dryland agriculture) (Betser, 2005). Fig. 3 clearly shows the shift from south to north of the $300 \mathrm{~mm}$ isohyet in the period 1984-1994 (Betser, 2005). This allowed the vegetation to progressively recolonize northward at approximately 4.3 $\mathrm{km} /$ year in the period 1982-2004 (Betser, 2005). From 1984 to 2017 , we can therefore estimate that the desert is set back to the north, on average, by about $140 \mathrm{~km}$.

\section{Impact of the African climate change on the wester yellow wagtail}

The western yellow wagtails face crossing the Sahara on a broad front (Cramp, 1988) and with an uninterrupted flight of 60-70 hours (Wood, 1982); it is therefore a very critical moment, especially in spring, for several factors:

- Individuals who winter in the Sahel must endure a long drought period (October to April) during which the arthropod biomass decreases proportionally with the decline of soil moisture (Gillon \& Gillon, 1974; Wood, 1976; 1978). The greatest scarcity of food is therefore precisely concurrent with the start of pre-breeding migration. Wood $(1976 ; 1992)$ found that during the last pre-migratory phase, the western yellow wagtails dedicate as much as $75 \%$ of the day time to feeding.

- During wintering in Nigeria, the weight of the birds is about $16-17 \mathrm{~g}$ and increases up to about $25 \mathrm{~g}$ in the imminence of the departure both for the accumulation of fats and for the hypertrophy of the pectoral muscles (Wood, 1982). When the western yellow wagtails arrive in Tripolitania, their weight is reduced to about $16 \mathrm{~g}$ with a loss of about $1 \mathrm{~g}$ every $200 \mathrm{~km}$ and therefore with a loss of about $0.6-1.0 \%$ of body weight for each hour of flight at the speed of 30-50 km/h (Fry et al., 1972). By comparison, on the European continent the average daily trips are $74 \mathrm{~km}$ with a documented maximum value of $189 \mathrm{~km}$ traveled in 6 hours, using up $0.7 \mathrm{~g}$ of fat (Lundwall \& Persson, 2006).

- By applying the formula of Pennycuick (1975), it is estimated that the maximum distance that the western yellow wagtail can cover with an uninterrupted flight is $2,040 \mathrm{~km}$.

As mentioned above, it is clear that the positioning of the border between Sahara and Sahel has a direct impact

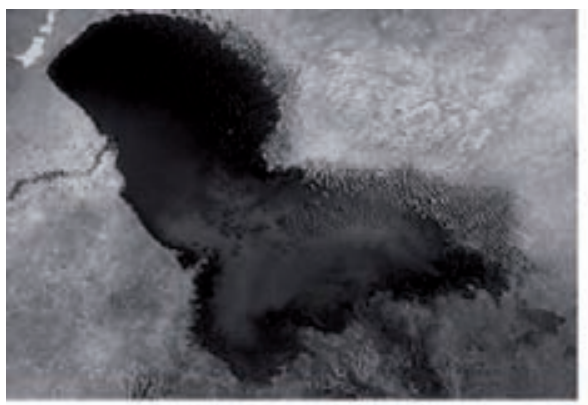

1963

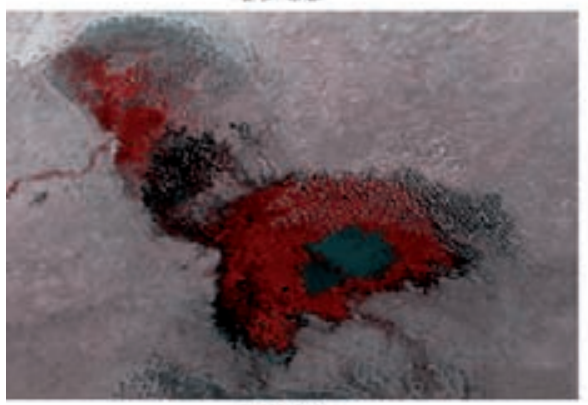

1997

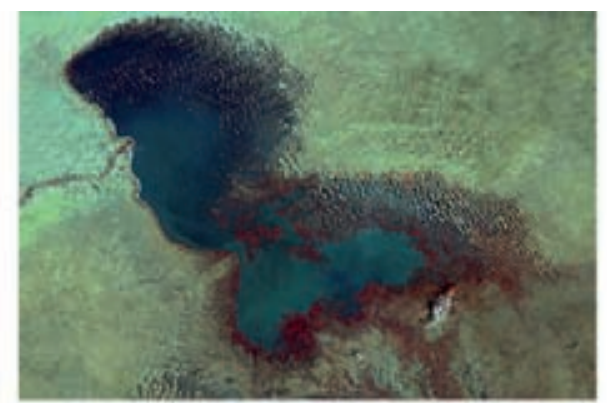

1973

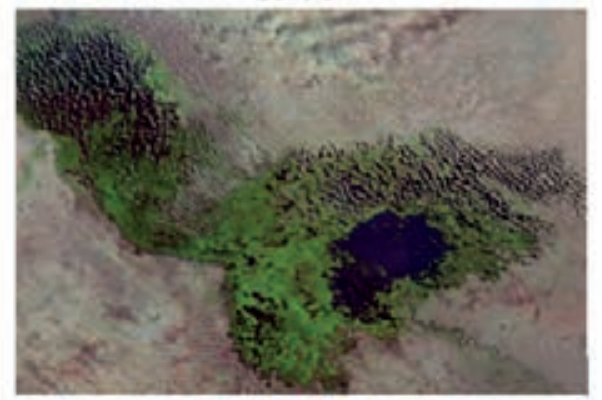

2001

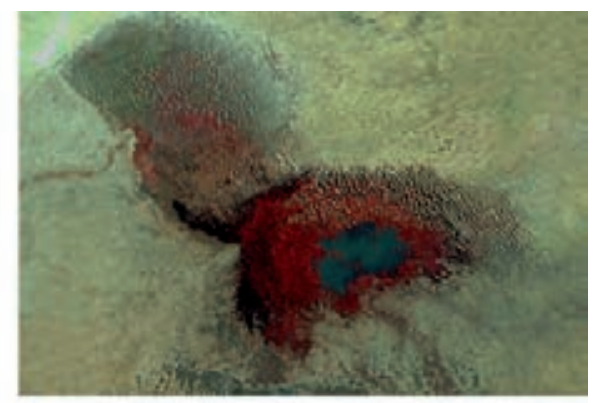

1987

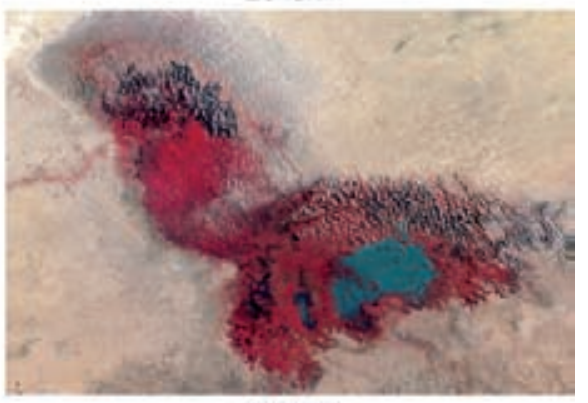

2017

Fig. 2 - Surface evolution of Lake Chad. / Evoluzione della superficie del lago Ciad (Source / Fonte: NASA/Goddard Space Flight Center Scientific. Visualization Studio). 


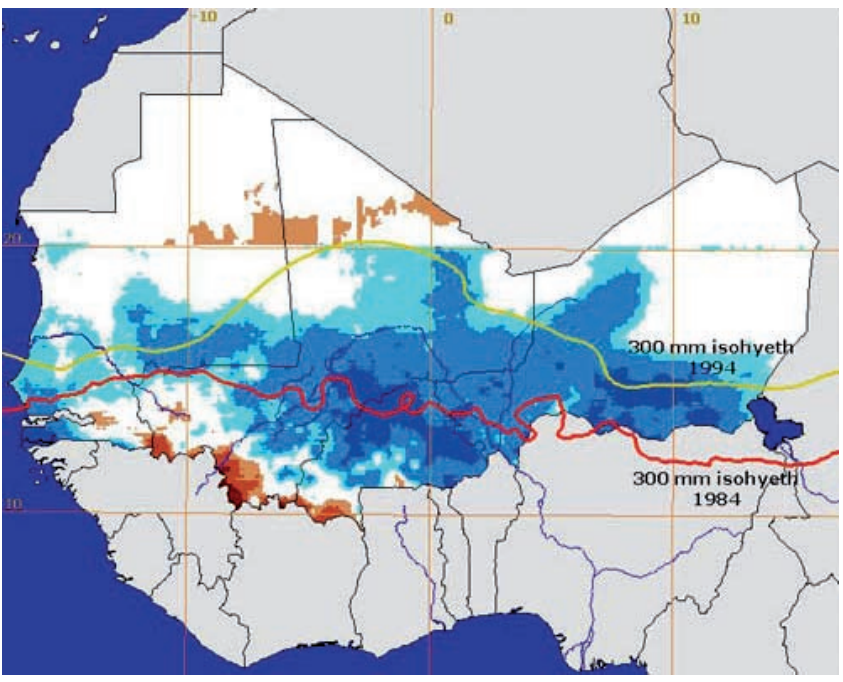

Fig. 3 - Rainfall trend 1982-2004, and the positions of the $300 \mathrm{~mm}$ isohyet in 1984 (red line) and 1994 (yellow line). / Tendenza delle piogge nel periodo 1982-2004 e posizioni delle isohyet dei $300 \mathrm{~mm}$ nel 1984 (linea rossa) e 1994 (linea gialla). (Source / Fonte: United Nations, 2008).

on the western yellow wagtail (as well as for other Palaearctic migrators) since the expansion of the desert during the dry phases requires the birds to spend more effort overflying and bring them to the limit of their physical capabilities with consequent increases in mortality (Hagemeijer \& Blair, 1997; Zwarts et al., 2012). This factor, certainly significant during the 1980 s, could have contributed, together with factors peculiar to the reproductive areas (Wilson \& Vickery, 2005; BirdLife International, 2017), to the decline of the species observed in Europe. The strong competition for the trophic resources found in the Sahel due to the progressive drying up of the soil from October to April could perhaps explain the presence in central Nigeria, both in Vom (Wood, 1976; 1979) and in Jos (Bell, 2006), of males (occasionally also females) of western yellow wagtails that for the entire wintering period defend small individual feeding territories $(0.1 \mathrm{ha})$. It is an unexpected behavior for a species that in the non-reproductive period lives without apparent difficulty in groups formed by hundreds or thousands of individuals which, in fact, could be induced by the scarcity of food resources. In confirmation of this, Wood (1979) found that, in the period of reduced availability of arthropods, a significant part of non-territorial individuals moved further south in search of areas with better food availability, while territorial individuals could avoid further migratory movements. The only other cases of territorial western yellow wagtails are known in Gabon and Democratic Republic of Congo, but in this case, the defense is practiced by small groups (3-6 birds) and not by individuals (Brosset \& Erard, 1986; Keith et al., 1992). With regard to future developments in the Sahel and Sahara area, recent studies suggest that rainfall could increase by 40 to $300 \%$ over the current century, owing to a northward expansion of the West African Monsoon domain (Schewe \& Levermann, 2017); if this happens, the Sahara will cease to be the main critical point during migration for the Palearctic birds. The effects of the increase in precipitation are already seen in Nigeria where the cultivated areas are expanding, even during the dry season, due to the use of irrigation techniques. With increasing frequency, the western yellow wagtails tend to move right into irrigated areas abandoning pastures with animals, their elective environment in previous decades (Bell, 2006).

Other areas frequented by the western yellow wagtail sensitive to climate change are those with savanna vegetation (Midgley \& Thuiller, 2011). During the last decades, the encroachment of woody plants has already affected savannas due to the increase in the concentration of $\mathrm{CO}_{2}$ (Ward, 2005; Buitenwerf et al., 2012); this trend is expected to accentuate over the course of the century in Central, Eastern, and Southern Africa (Wigley et al., 2009; 2010; Buitenwerf et al., 2012; Higgins \& Scheiter, 2012; Mitchard \& Flintrop, 2013; Ziervogel et al., 2014) thus reducing the areas that can be used for grazing by herbivores to which Motacilla flava is expected to obtain a trophic advantage with foreseeable impacts on the wintering areas of the latter.

Since it is expected that temperatures in Africa can rise faster than the global average increases during the $21^{\text {st }}$ century (Christensen et al., 2007; James \& Washington, 2013), in consideration of what has already been observed in Europe during the breeding season (Ferlini, 2015; 2016), it is possible that the western yellow wagtail will also use mountain grasslands at higher altitudes than the current limit (about 3,000 $\mathrm{m}$ a.s.l.) in the future.

\section{Change in wintering range of Motacilla flava in Europe (Plate 1)}

With regard to Europe, the expansion of the western yellow wagtail wintering range in the continent has been particularly evident. In fact, if presences until 1975 were sporadic and attributed to individuals unable to face or continue the migration, the species then began to appear in southwestern countries (Spain, Portugal, and Italy) in limited numbers in the 1980s and then with increasing regularity and abundance beginning in the 1990s. In this geographical area, specially in Spain, presences were limited only to climatically favorable zones that maintain a sufficient availability of invertebrates in winter (Tellería, 1988; Pérez-Tris \& Asensio, 1997). From the $21^{\text {st }}$ century, the presences were then extended to the islands of the Southeastern Mediterranean Sea (Malta, Crete, Cyprus) and, perhaps less predictable considering the different climatic conditions, to Western Europe (France, Switzerland, Austria, Germany, United Kingdom) and Scandinavia.

\section{European winter climatic conditions}

Considering the different environmental characteristics of the European countries where the western yellow wagtails were observed in December and January, it can be considered that the only abiotic factor that may have affected their presence is the climatic one. In Europe in winter, the temperature distribution clearly reflects the increase in thermal continentality along an east-west gradient: the process is driven by the exchange of air masses 


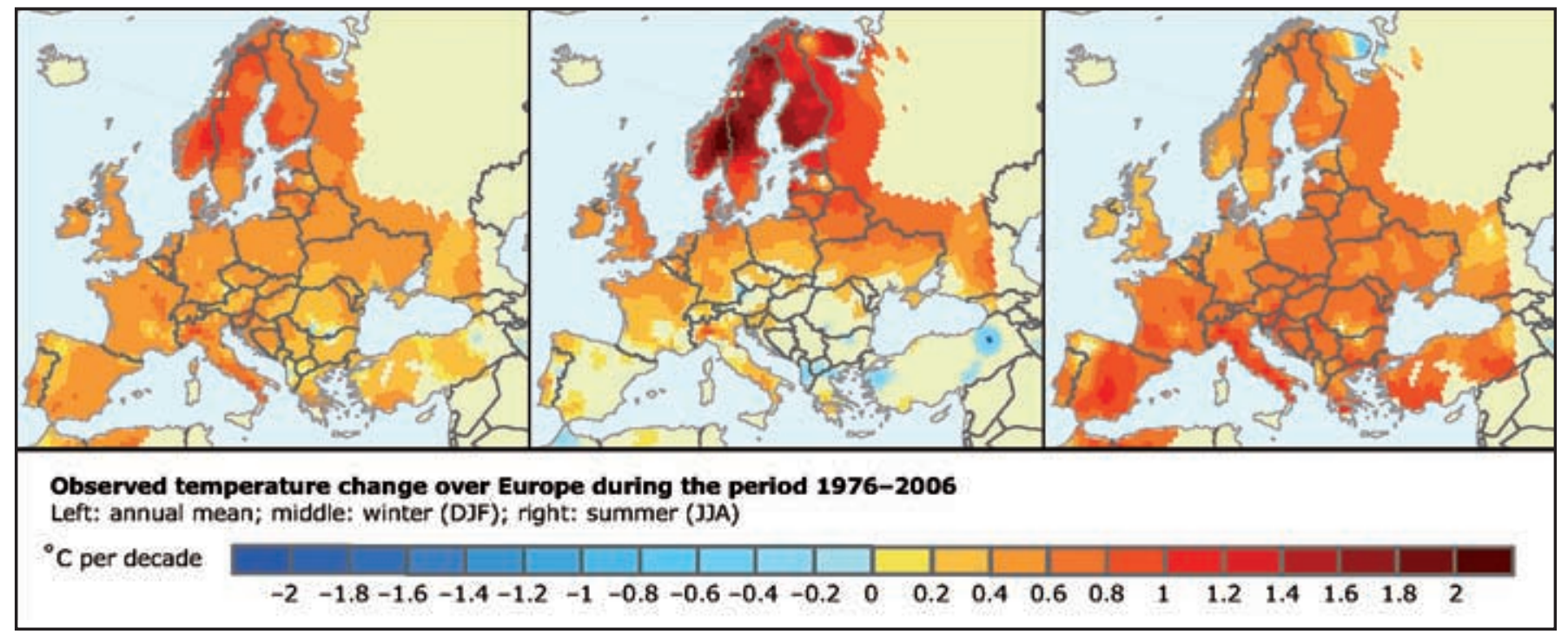

Fig. 4 - Observed temperature change over Europe during the period 1976-2006 (left: annual mean; middle: winter (DJF); right: summer (JJF). / Variazione della temperatura osservata in Europa durante il periodo 1976-2006 (sinistra: media annuale; centro: inverno (DJF); destra: estate (JJF). (Source / Fonte: EEA, 2009).

triggered by the westerly Gulf Stream and the high- and low-pressure areas which form below it (Westermann, 2010). After periodic fluctuations in the temperatures observed at continental level during the $19^{\text {th }}$ and $20^{\text {th }}$ centuries, from the 1980s a generalized increase was observed (especially in Scandinavia in winter) (Fig. 4).

The decadal average temperature over land area for 2002-2011 was $1.3{ }^{\circ} \mathrm{C}$ above the $1850-1899$ average (Kovats et al., 2014) and became $1.5^{\circ} \mathrm{C}$ above the preindustrial level for the decade 2006-2015 (the warmest decade on record) (EEA, 2017). Since 1950, annual precipitation has increased in Northern Europe (up to +70 $\mathrm{mm}$ per decade) and decreased in parts of Southern Europe (Kovats et al., 2014). The beginning of the rise in the average temperature in Europe coincided temporally with the beginning of wintering by Motacilla flava in the south of the continent, and the expansion of their presence towards the north could be correlated with the equivalent increase in temperatures. In particular, it can be noted that in Western Europe the wintering range of the western yellow wagtail is included in the area characterized by positive January isotherms, and the limit, with a good approximation, is constituted by a $0{ }^{\circ} \mathrm{C}$ January isotherm that runs along a line from Western Scandinavia through Hamburg to the French Limestone Alps (Fig. 5) (Westermann, 2010).

\section{Oversummering range of Motacilla flava in sub- Saharan Africa (Plate 2)}

In the past, some authors have reported the occasional presence of western yellow wagtails during the austral winter (June, July, August) in the Democratic Republic of Congo (Schouteden, 1963; Herroelen, 2006), in Transvaal (Tarboton et al., 1987; Keith et al., 1992), and in Namibia (Koen, 1988). In Zambia, a specimen on $5^{\text {th }}$ July 1908 was observed at Lake Bangweulu (Neave, 1910).
In Uganda, a specimen was captured on $2^{\text {nd }}$ June 1916 on Mount Elgon (Trombone, 2013). In South Africa, there are historical data with a specimen attributed to the ssp. thunbergi captured on $17^{\text {th }}$ August 1880 in the Cape Province (Telenius \& Ekström, 2017) and a M.f. lutea was collected in Warmbath (the current Bela-Bela) (Limpopo Province) on $5^{\text {th }}$ July 1916 (Museums Victoria, 2016). In Namibia until 1988, at least seven reports were known (Koen, 1988). In the Democratic Republic of Congo, a young individual from that year was observed in Aru (Oriental Province) on 12 $2^{\text {th }}$ August 1952 (Schouteden, 1963; Herroelen, 2006).

The oversummering by Palearctic birds in Africa during the boreal summer (rather than migrating north) is common in immature individuals of most species of nonpasserines (specially waders, terns, and raptors), but is very uncommon for passerines (e.g. northern wheatear

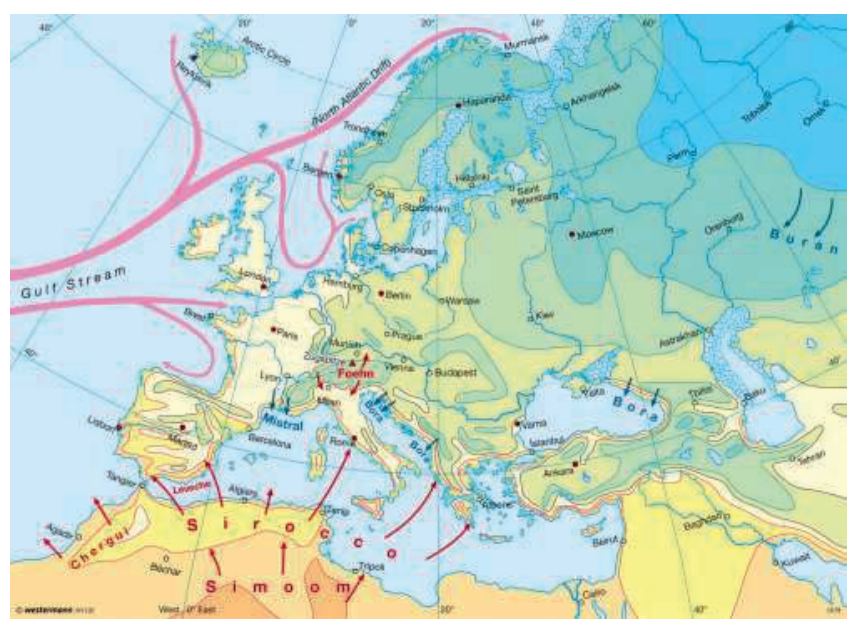

Fig. 5 - European January isotherms. / Isoterme di gennaio in Europa. (Source / Fonte: Westermann Schulbuch, 2010). 
Plate 2 - Oversummering range of Motacilla flava in sub-Saharan Africa. / Areale estivo di Motacilla flava nell'Africa sub-sahariana.

Single ind.

2-10 ind.

$11-100$ ind.

$101-1,000$ ind.

$1,001-10,000$ ind.

Over 10,000 ind.

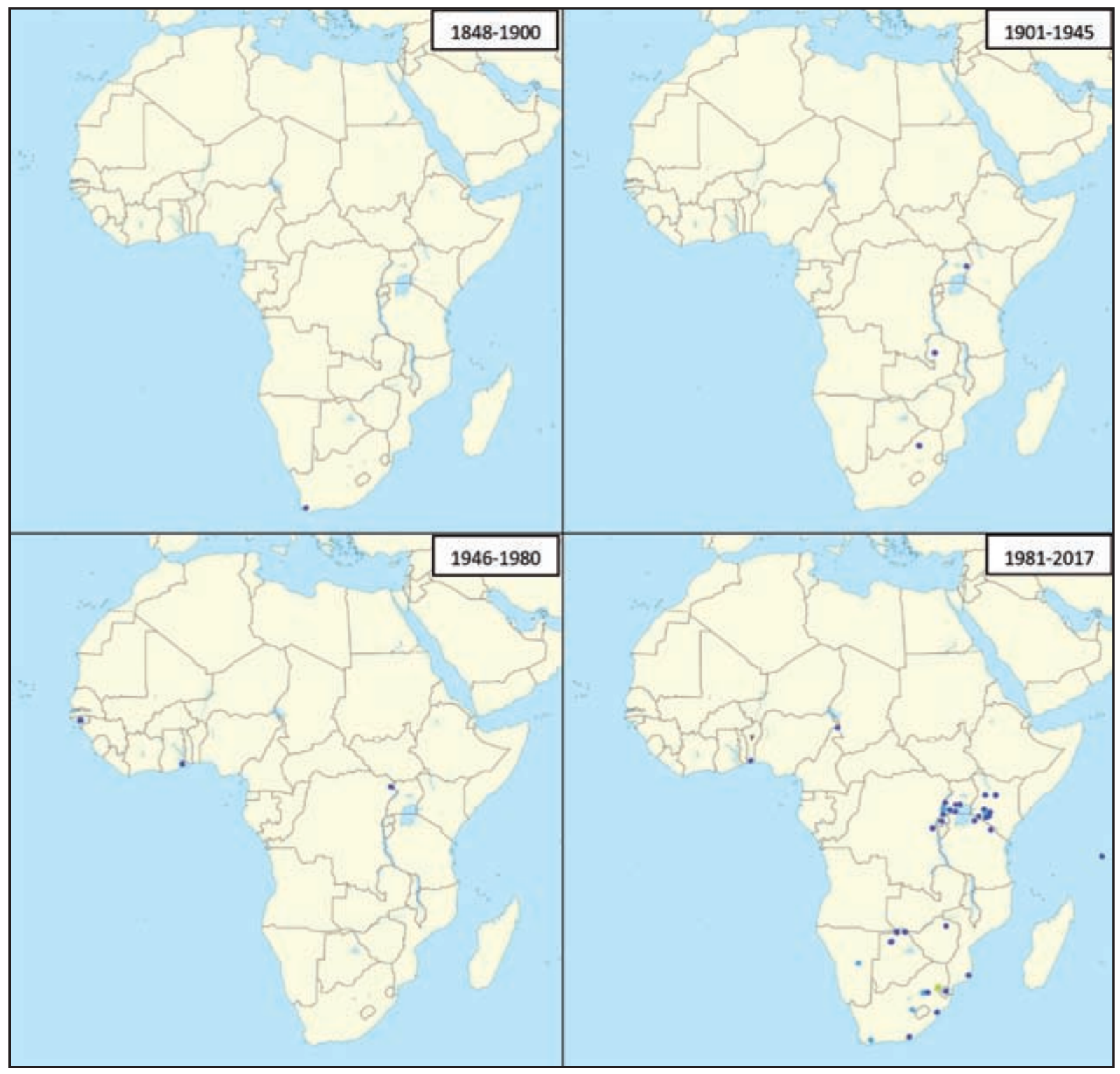

Oenanthe oenanthe, icterine warbler Hippolais icterina, garden warbler Sylvia borin) (Pearson \& Britton, 1980; Lewis \& Pomeroy, 1989; Newton, 2011; Oschadleus \& Ranwashe, 2017), so it is interesting to consider the new data acquired after the publication of the book by Keith et al. (1992):

- In South Africa, between 1997 and 2016 there were at least 15 reports from June to August (Levatich \& Padilla, 2016; Brooks, 2017a; 2017b; Observation. org, 2017). A recent observation (31 $1^{\text {st }}$ July 2017) also concerns Swaziland (Observation.org, 2017). Five reports from South Africa refer to groups of western yellow wagtails: two specimens in July 1997 (Gauteng), seven in July 2001 (Mpumalanga), seven in July 2002 (Western Cape), as many as 28 individuals in July 2004 (Mpumalanga) and seven in July 2005 (Free State) (Levatich \& Padilla, 2016; Brooks, 2017a; 2017b; Observation.org, 2017).

- In Namibia, there were at least four other observations between 2004 and 2010, including one involving two individuals present on $15^{\text {th }}$ August 2004 at the Daan Viljoen Game Reserve and one related to four specimens observed on $17^{\text {th }}$ July 2010 (probably attributable to lutea) (BirdForum, 2004; Levatich \& Padilla, 2016; Observation.org, 2017).

- In Botswana, on $27^{\text {th }}$ July 2008 a specimen of the ssp. lutea was seen in the Okavango Delta (Observation. org, 2017).

- Between 1997 and 2014 in Tanzania, Rwanda, Mozambique, and Zimbabwe, there were sporadic 
occurrences of individuals between July and August (Coetzer \& Ranwashe, 2015; Levatich \& Padilla, 2016; Observation.org, 2017).

- In Alphonse Atoll (Seychelles), one specimen was observed on $5^{\text {th }}$ July 1995 (Levatich \& Padilla, 2016).

- In Democratic Republic of Congo, one individual was reported on $1^{\text {st }}$ August 1993 in South Kivu Province (Levatich \& Padilla, 2016).

- In Kenya, between 1983 and 2017, there were at least 10 reports of isolated individuals with the exception of the observation of two specimens on $9^{\text {th }}$ July 2003 near Lake Naivasha (Pearson, 1983; Backhurst, 1986; Levatich \& Padilla, 2016; Naturgucker, 2016; Observation.org, 2017).

- In Uganda, from 1993 to 2017 there were at least 10 reports of which one related to five individuals, one to six individuals, and one to two individuals; all others concerned isolated specimens (Calabuig, 2013; Coetzer \& Ranwashe, 2015; Tushabe, 2015; Levatich \& Padilla, 2016).

- Regarding Cameroon, I found only the reference for a specimen on $11^{\text {th }}$ August 2008 near the Mungoyeck village (near Maga) (Coetzer \& Ranwashe, 2015).

- In Western Africa (Bénin, Ghana and Guinea Bissau), the reports are scarce (only four in 170 years) and all characterized by different levels of uncertainty.

The data suggest a possible intensification of the presence of Motacilla flava in sub-Saharan Africa between June and August, and starting from the 1990s (limited to the eastern part of the continent), the northward expansion of the geographic area was affected by the phenomenon. The reports are numerically significant, especially in Kenya and Uganda, where there are already consistent concentrations of western yellow wagtails during the boreal winter. Surprising, however, is to note the repeated presence of Motacilla flava in South Africa during the austral winter, because the abundance in December-January in this area is much lower than those of the aforementioned equatorial countries. Even more surprising is the presence in South Africa of a group of as many as 28 individuals in July. This apparent accentuated presence in Eastern Africa suggested by the new data should probably be evaluated with caution and over time due the increased number of observers with a consequent increased probability of detection of the species. The absence of the species remains confirmed in the zone between the equatorial area and the southernmost latitudes of nesting (Banc d'Arguin in Mauritania to the west and the Aswan area in Egypt at east). With regard to the temperatures of the month of July, almost all of the observations are concentrated in areas included between the isotherms of $20{ }^{\circ} \mathrm{C}$ and $10{ }^{\circ} \mathrm{C}$ (Fig. 6). Finally, the presence of first yearyoung in the Democratic Republic of Congo on $12^{\text {th }}$ August 1952 deserves a comment. Excluding an error of identification of the specimen, is it possible to imagine that a young individual may have already migrated from Europe or North Africa to the middle of Africa at the beginning of August when the first arrivals usually take place in the second half of September? This unusual presence could suggest a possible local nesting, of which, however, be uncertain.

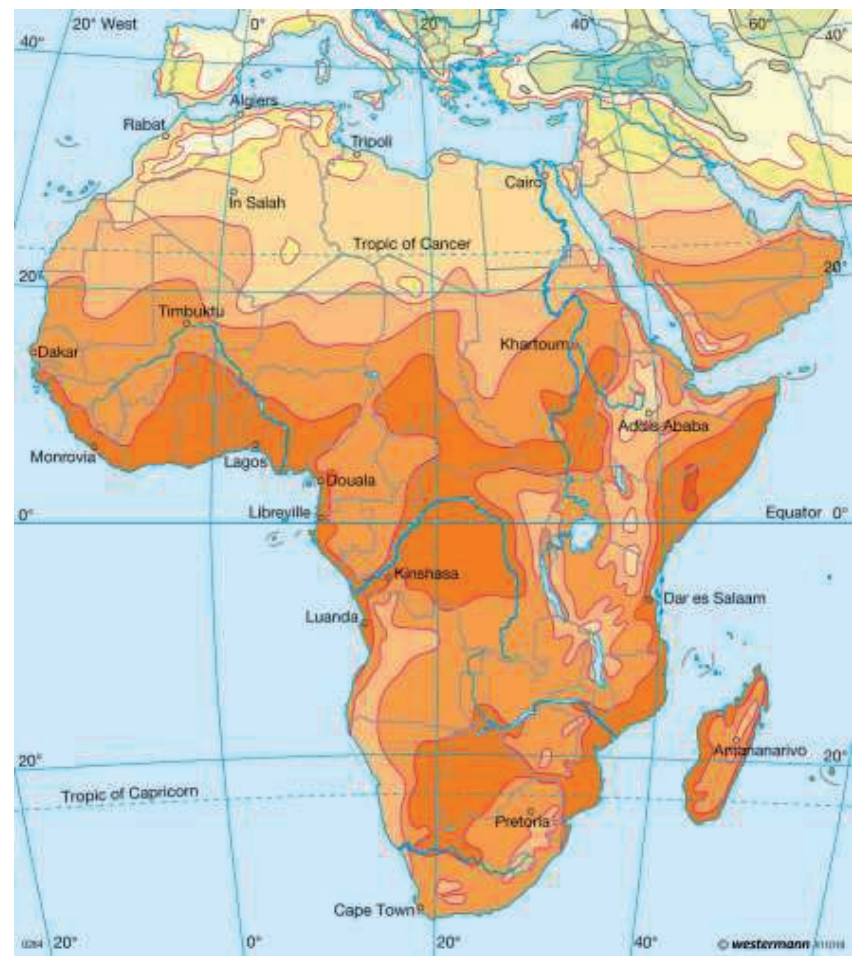

Fig. 6 - African July isotherms. / Isoterme africane di luglio. (Source / Fonte: Westermann Schulbuch, 2010).

\section{Wintering range of Motacilla flava flavissima (Fig. 7, Plate 3)}

The data relating to the subspecies in the second half of the $19^{\text {th }}$ century show a distribution quite similar to the corrent one, with more authors attesting with certainty the wintering of yellow-headed wagtail in Nigeria (in the Nasarawa State) and in the northern highlands (Hartert, 1886; Shelley, 1900). In the following period (19011945), an evident confusion between flavissima and lutea was generated among the ornithologists. In fact, while the presence in Western Africa was confirmed, there were many reports of individuals attributed to flavissima also in Eastern Africa (Kenya, Uganda, Democratic Republic of Congo). The debate about the presence of the subspecies flavissima in Eastern and Southern Africa lasted until the 1970s. Authors such as van Someren (1931), Grant \& Mackworth-Praed (1942), Benson (1946), Wallace (1955), Mackworth-Praed \& Grant (1957), Archer \& Godman (1961), and Fintha (1988) considered the migration of the British race to the eastern parts of Africa, from Somalia to Southern Rhodesia possible. That these apparent flavissi$m a$ are derived from the small yellow-headed population breeding in Western Europe has been considered highly unlikely by Smith (1950), Williamson (1955), Moreau (1961; 1972), Dowsett (1965), Pearson (1972), Britton (1980), Ash \& Miskell (1983), Clarke (1985), and Carswell (1986). A significant contribution towards defining the real situation was the study conducted by Pearson \& Backhurst (1973). These researchers, through the ringing and recapture of individuals of yellow-headed wagtail near Nairobi (Kenya), found that: 
Plate 3 - Wintering range of / Areale di svernamento di Motacilla flava flavissima.

\begin{tabular}{l|l|l|l|l|l|} 
Single ind. & 2-10 ind. & $11-100$ ind. & & $101-1,000$ ind. & $1,001-10,000$ ind.
\end{tabular}

Over 10,000 ind.

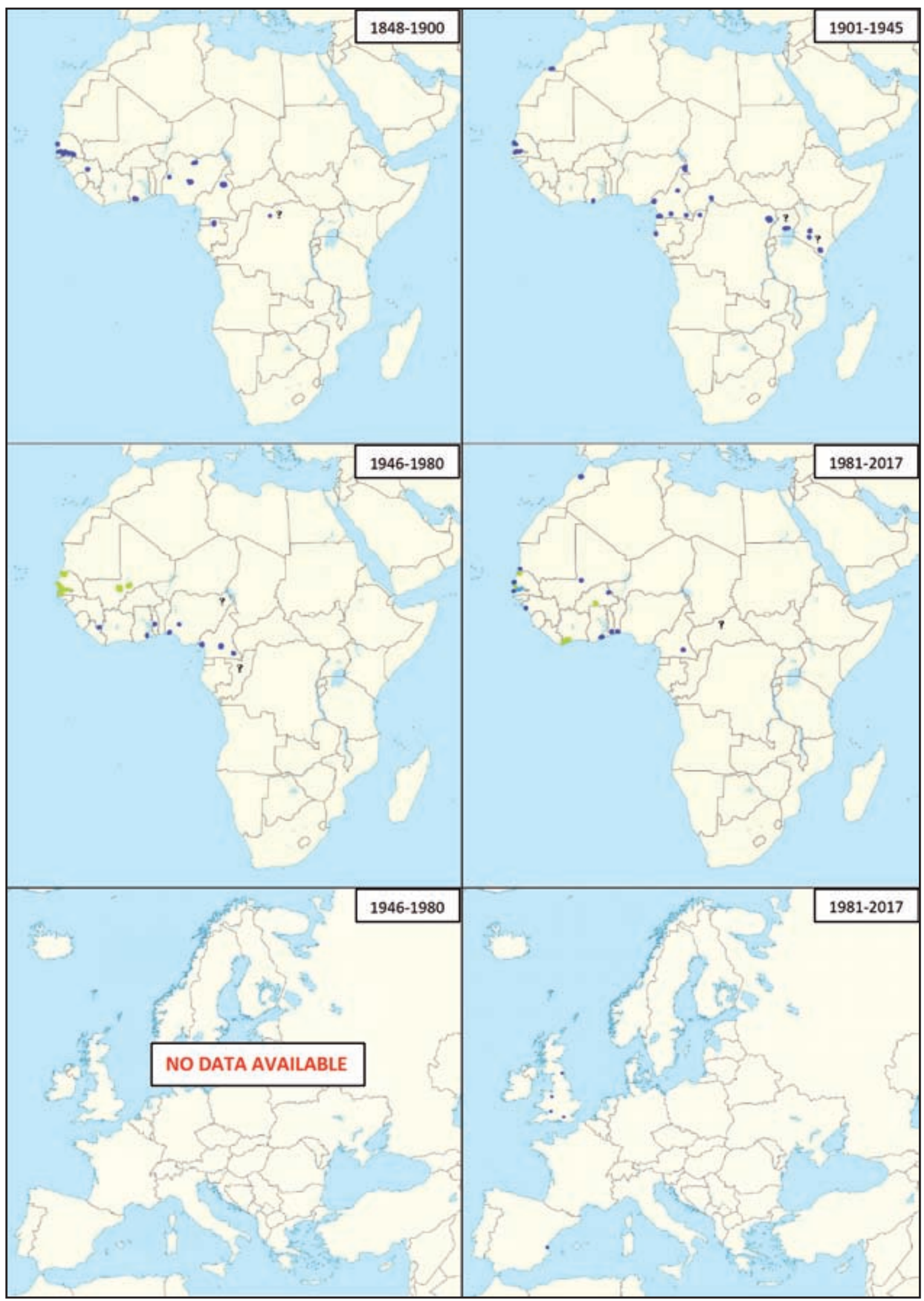




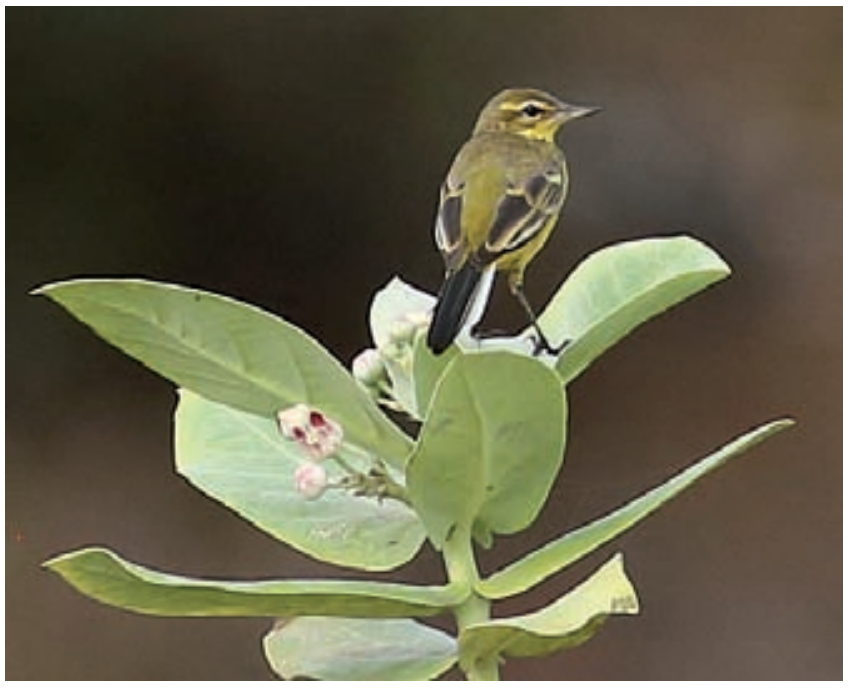

Fig. 7 - Motacilla flava flavissima, 22 ${ }^{\text {nd }}$ January 2017, Sakamono Lagoon, Greater Accra Region, Ghana. / Motacilla flava flavissima, 22 gennaio 2017, Laguna di Sakamono, Regione della Grande Accra, Ghana. (Photo / Foto: Klaus Malling Olsen)

«... among the yellow-headed birds the majority in March and April were 'typical lutea', but half the adults and over $90 \%$ of the first-year birds trapped in winter before prenuptial moult were 'flavissima-like' (green or brownish forehead uniform with the crown and ear coverts, and yellow confined to the throat and supercilium).».

The same authors also recalled that:

«... five Yellow Wagtails from Kariobangi or nearby had been recovered in the Palaearctic, one (a female) on spring passage in Qatar, and four (three females and a yellow-headed male) in Russia between 51" and 59" N and $45 "$ and $81 "$ E».

From 1960 to $1981,49,681$ western yellow wagtails were ringed in Eastern Africa; 26 individuals ringed in Kenya were caught again in the Union of Soviet Socialist Republics, Saudi Arabia, Iran, Qatar, and Tanzania (Backhurst, 1981; 1988). The western yellow wagtails in Kenya that were attributed to the ssp. flavissima for a long time were in reality both adults and, mainly, firstyear birds of the ssp. lutea, as confirmed by the catches in places located northeast of the ringing area in Africa. This is also probably true for the flavissima observed by CurryLindahl (1965) in the Congo for which, in fact, there was no consistency between migration times and the development of the gonads. Also, the reports of flavissima in Somalia are due to lutea (Ash \& Miskell, 1983). Since the Second World War, the subspecies is relatively common in some suitable environments of Western Africa, going east to Southwestern Nigeria. The subspecies from the reproductive area reaches Africa converging towards the western half of the Iberian Peninsula to finally cross the Strait of Gibraltar (Pérez-Tris \& Asensio, 1997; de Juana $\&$ Garcia, 2015). During post-breeding migration, some specimens were also observed in Southern Germany (e.g. a specimen on 30 August 2015 in Heidelberg-Grenzhof in Baden-Württemberg) (Avifaunistische Kommission Baden-Württemberg, 2016), in Switzerland (4-5 reports from 1992 to 2014) (Marques \& Thoma, 2015), and Italy (a do- zen reports, all along the peninsula, distributed between the first ten days of August and mid-October). This leads to the hypothesis, in the absence of objective evidence consisting of ringed individuals, of the existence of a small migratory flow that, after crossing the Italian peninsula, reaches Africa crossing the central Mediterranean. If so, where are these individuals wintering? The analysis of the data of specimens ringed in Nigeria and captured elsewhere, as well as those of individuals ringed in Europe and taken back to Nigeria, have highlighted the existence of a clear migratory route that, starting from Scandinavia, crosses Central and Eastern Europe, Italy, Malta, Tunisia, Libya, Niger, and Chad to reach Nigeria (Sharland, 1964; 1965; 1966; 1967a; 1967b; 1968; 1969; 1972a; 1972b; 1974; 1975; 1978; 1979; 1985; 1996; Wood, 1975). This justifies the wintering in this country of the subspecies thunbergi, flava, feldegg, and cinereocapilla. The individuals of ssp. flavissima observed in transit in Italy could belong to the part of the most eastern population nesting along the North Sea coast (from Belgium to Norway). These could migrate together with the other subspecies listed above and this would justify the observations of the western yellow wagtail with a yellow head occasionally present at Lake Chad (Fry et al., 1972) and Nguru (Nigerian Sahel) (Bell, 2006). In the past, it has been hypothesized that the specimens observed at Nguru could belong to Central European breeding populations (Bell, 2006), while according to Wood (1975), three specimens observed at Lake Chad could more probably be attributed to lutea. In my opinion, the flavissima hypothesis should be considered, especially for the data concerning pre-reproductive migration: the subspecies, in fact, was observed in Tunisia (five individuals on $18^{\text {th }}$ March 2014 in the Korba lagoon, Nabuel Governatorate) (Smith, 2014), in Linosa (an individual on $27^{\text {th }}$ April 1967) (Moltoni, 1970), along the Italian peninsula, Sardinia, and Corsica (Moltoni, 1971; Brichetti \& Fracasso, 2007), and was more accentuated with respect to post-breeding migration, from mid-March to mid-May, peaking in the last two decades of April. The timing of transit in Italy is very similar to that observed in Switzerland where, however, the subspecies is reported more frequently (81-82 observations on a total of 84-85 individuals until $31^{\text {st }}$ December 2015) (Martinez \& Maumary, 2016). These individuals could be those potentially wintering in Nigeria to which other specimens could be added coming from the nearest areas where the presence of the subspecies is documented (Burkina Faso, Togo, Bénin), because during the pre-breeding migration, the species in Western Africa tends to follow a more easterly route than in autumn (Cramp, 1988; Wernham et al., 2002; Gargallo et al., 2011). However, there is still doubt about attributing the correct subspecies for the western yellow wagtail with the yellow heads observed in Cameroon, Gabon, and Congo. In this area, the reports during the period 1901-1945 were numerically limited, but widespread, and in time they became increasingly scarce. On the basis of the foregoing considerations, it could be noted that Cameroon, Gabon, and Congo are on the same migratory route which, descending from Scandinavia, crosses Italy, the central Mediterranean, and then reaches Nigeria, and therefore it is possible to assume these presences can 
be attributed to the subspecies flavissima. Another factor, concomitant and compatible with the previous one which could lead to the same conclusion, is what was observed by Gatter (1987) about Palaearctic bird migration in Western Africa according to which:

«... from November until at least January, another south-east movement occurs, which is induced (food shortage, aridity) and supported (tail winds) by the northeast trade wind or harmattan. Part of the population continues migration to the equatorial region and probably even further south.».

The greater frequency of reports in Cameroon were recorded in the years 1932-1964. Probably this coincided with the peak reached by the population of flavissima during the reproductive phase in Europe: at least since 1923, the subspecies began to nest in Netherlands; in the 1930 s and 1940s, the subspecies colonized the north of Germany, the Helgoland Islands and the Frisian Islands, then reached the south of Norway in 1947 (Bernis, 1970). The progressive decrease in the number of observations could be related to the numerical decline of the subspecies in the reproductive area (-43\% in United Kingdom from 1995 to 2013; Hayhow et al., 2014), including the part of the population that reproduces on the coasts of North Sea (e.g. in the Netherlands nesting pairs have decreased from $150-200$ in 1975 and $200-350$ in 1980 s to an estimated $40-80$ in $1998-2000$ and $25-40$ in 2008-2011; SOVON, 2002; 2017).

The presence of individuals with a yellow head more to the east, in the Central African Republic, remains still undefined. Here the flavissima/lutea subspecies was reported at the beginning of the $20^{\text {th }}$ century in the Kémo Prefecture (Oustalet, 1904-1905) and was frequently found in the 1980-82 period in the Bamingui-Bangoran National Park (Green, 1984). Considering that this Park is far from the area of normal presence of the ssp. lutea, that the period of observations coincide with the maximum abundance of flavissima along the coast of the North Sea, and that the basin of the River Chari and rice cultivations in the plain between the Rivers Logone and Chari can constitute a good ecological corridor connecting Lake Chad to the Park, I favor the hypothesis that the individuals observed by Green (1984) were attributed to flavissima. Obviously, these are purely speculative considerations that I hope can be better defined or corrected through the acquisition of data supported by scientifically acceptable evidence in the future.

Morocco was indicated as a wintering area for the subspecies by Alström et al. (2003), but I have found only one specific data, so I hypothesize that the abundance of the subspecies is rather limited. The Iberian Peninsula remains the main route for pre-breeding migration, however, the spring flow occurs on a larger front; in fact, ringed individuals were captured both in the western and in the eastern part of the Peninsula (Cramp, 1988; PérezTris \& Asensio, 1997; Tellería et al., 1999; Wood, 2002; de Juana \& Garcia, 2015). The individuals of the ssp. flavissima that migrate north along the Mediterranean coast of Spain are probably those observed migrating in France, in Camargue, and along the Rhône Valley from the first ten days of April to the first ten days of May (Hafner et al., 1980; Réserve Nationale de Camargue, 1987; Boutin
\& Cherain, 1989; Kayser et al., 2008; Tissier, 2015) and that, in part, could reach Switzerland following the path of the river. This could explain the number of observations made in Switzerland that are much higher than expected if these were only due to the small flow that goes back north following the route of the central Mediterranean and passing through Italy. Exceptionally the subspecies winters in Spain and United Kingdom.

\section{Wintering range of Motacilla flava flava (Plate 4)}

The distribution of the subspecies flava in Africa coincides with a good approximation of the species as a whole; in fact, it is widely distributed in the continent and is the most abundant subspecies almost everywhere. Since the 1970s, the subspecies has been observed in Egypt, with a tendency to increase the number of wintering individuals (over 1,000 near Luxor in December 2012) and its range is expanding north along the River Nile (also present in its delta in December 1999) (Grieve, 2000; Prescott, 2012). The subspecies has also been reported in the last decades in Cyprus, Greece, Italy, and Spain, but it is probable that individuals observed in Central Europe are also attributable to the ssp. flava, as is the case of the specimen observed in late November in Netherlands.

\section{Wintering range of Motacilla flava thunbergi (Fig. 8, Plate 5)}

The $19^{\text {th }}$ century data for this subspecies were very scarce and, curiously, related to extreme points of the wintering range of the species in that period: in Egypt, South Africa, and Namibia. Overall, the distributions during the $20^{\text {th }}$ and the beginning of the $21^{\text {st }}$ century confirm a prevalent presence in sub-Saharan Africa with the exception of the western part of Middle Africa. Local concentrations are found in Western Africa (between Ghana and Nigeria), Ethiopia, and Uganda. The presence of the subspecies (with a possible numerical increase in the last decades) is confirmed in Egypt (in the Luxor area). The distribution along the coast of Western Africa seems to have had a significant evolution, in fact Shelley (1900), referring to the situation at the end of the $19^{\text {th }}$ century, pointed out that no data were known concerning the subspecies, and until the 1980s, there were only sporadic reports in Sierra Leone (Bannerman, 1936) and Liberia (Torben, 1950). This is a rather strange situation, because although very limited, the transit of the subspecies during migrations in Spain and Morocco was already recorded in the first half of the $20^{\text {th }}$ century (Hartert, 1928; Bernis, 1954) and confirmed in the 1960s in Spain, Morocco, and Senegal (Bernis, 1970). Subsequently, a growing presence was noted in the countries bordering the Gulf of Guinea, and along with the extension of the wintering range along the west coast in Gambia, Senegal, and with isolated individuals, also Morocco. The winter presences along the West African coast are probably favored by the migratory flow of the subspecies along the Scandinavian-Iberian route, which manifests itself through a regular transit along the Iberian Peninsula: $3 \%$ of the over 76,000 western yellow wagtails ringed in Spain from 1973 to 2009 are thunbergi; the pre- 
Plate 4 - Wintering range of / Areale di svernamento di Motacilla flava flava.

\begin{tabular}{|l|l|l|l|l|l|l|} 
Single ind. & 2-10 ind. & $11-100$ ind. & 101-1,000 ind. & $1,001-10,000$ ind. & Over 10,000 ind.
\end{tabular}

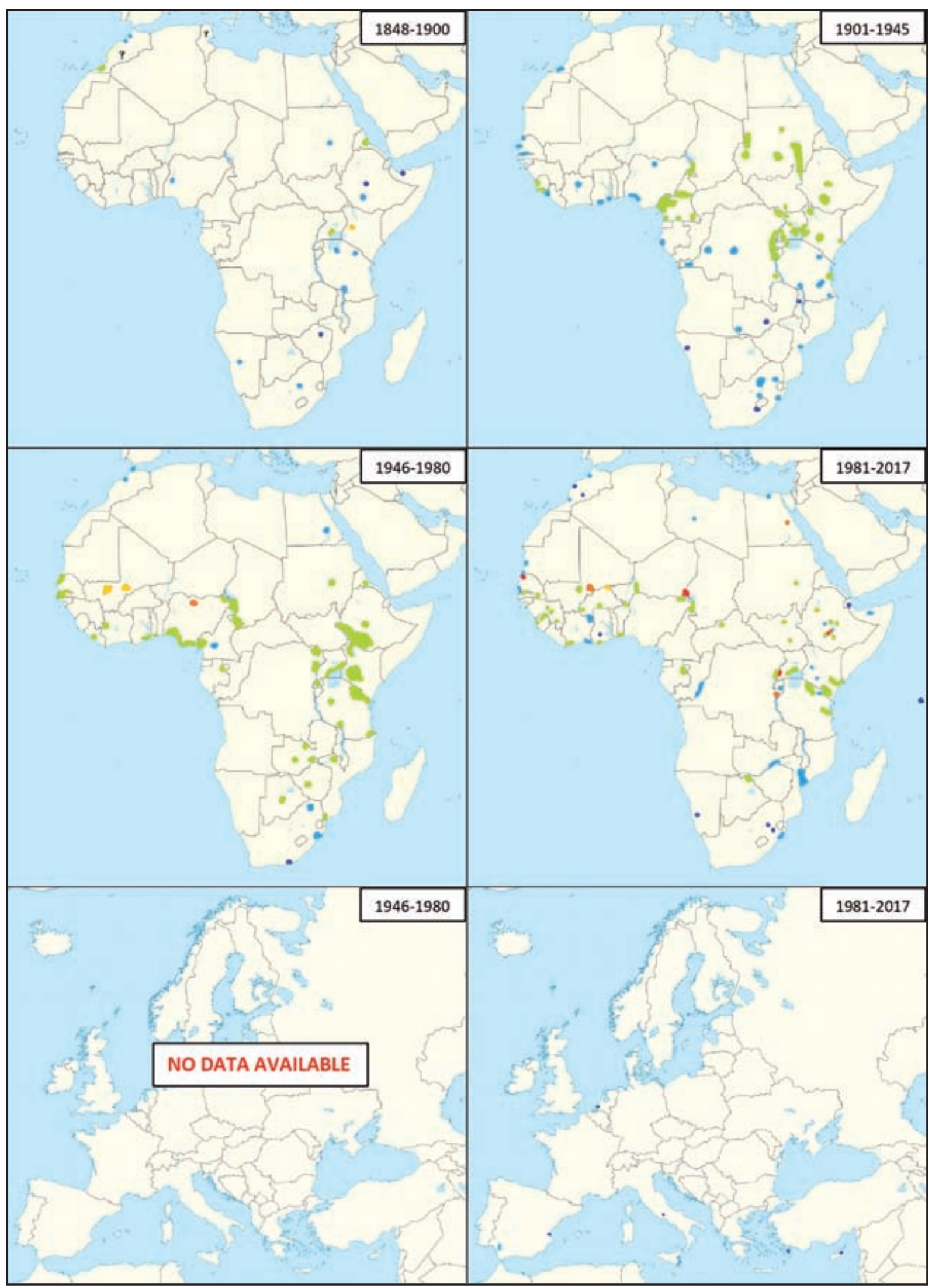


Plate 5 - Wintering range of / Areale di svernamento di Motacilla flava thunbergi.

Single ind. $\quad$ 2-10 ind. $\quad$ 11-100 ind. 101-1,000 ind. 1,001-10,000 ind.

Over 10,000 ind.

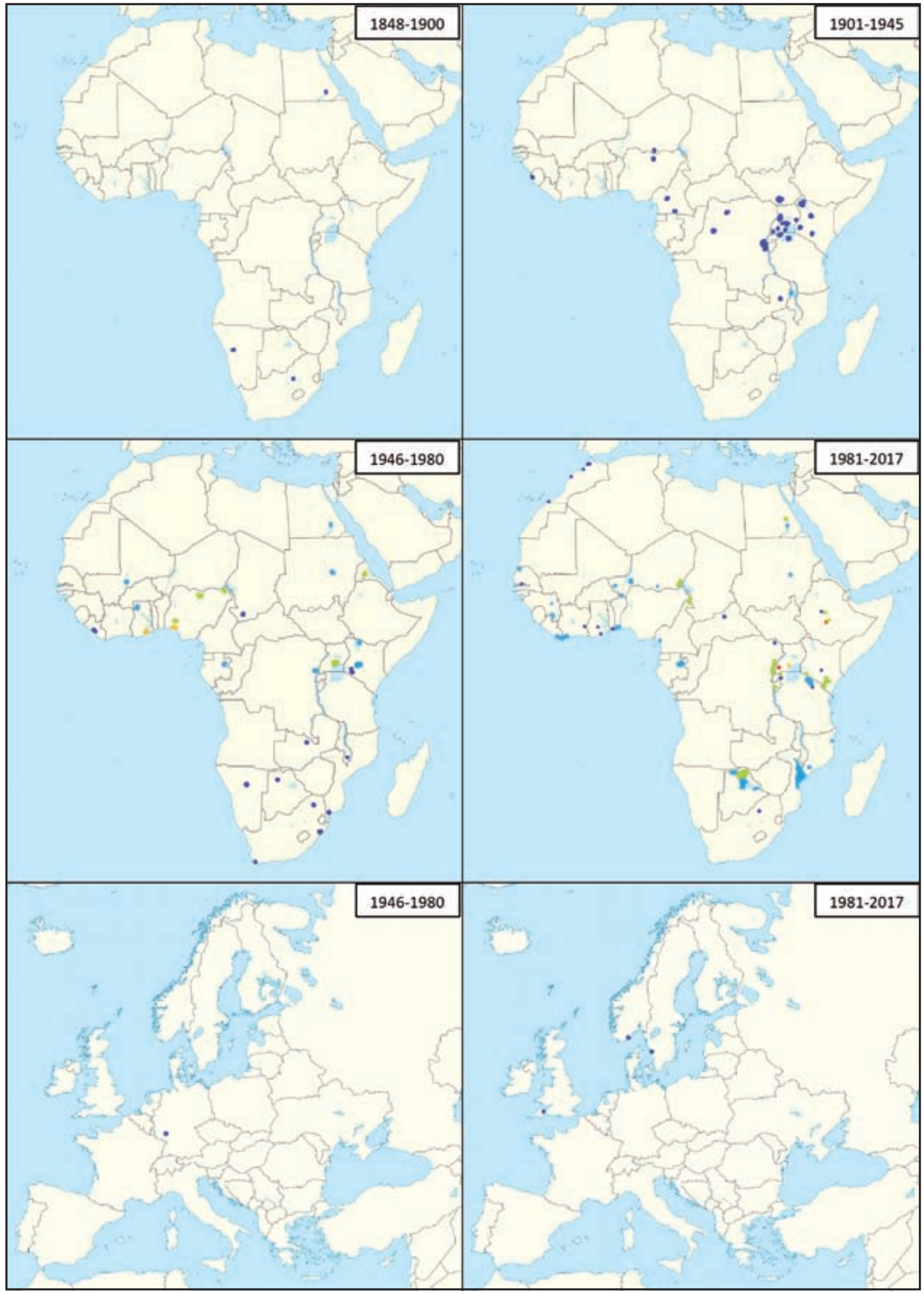




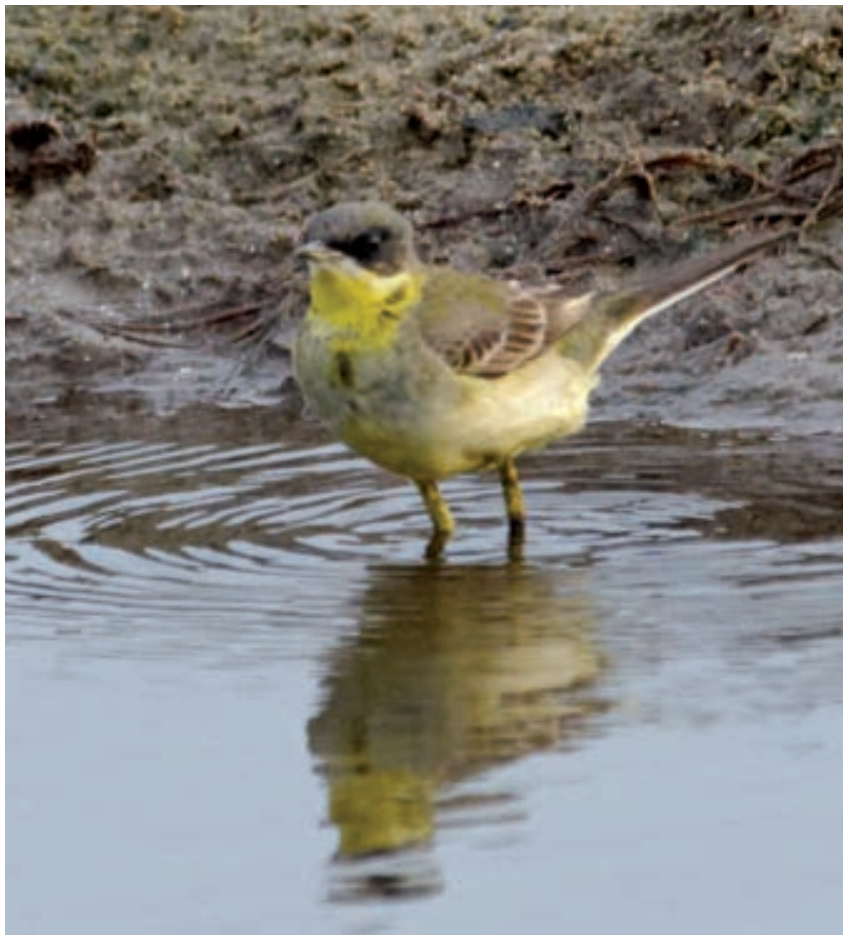

Fig. 8 - Motacilla flava thunbergi, February 2012, Cotonou harbour, Bénin. / Motacilla flava thunbergi, febbraio 2012, porto di Cotonou, Bénin. (Photo / Foto: Bruno Portier).

sence is more abundant on the western half of the Iberian Peninsula and Balearics (at Ebro delta 14\% of the western yellow wagtails ringed in the autumns of 1992-1995 are thunbergi) (Finlayson, 1992; Pérez-Tris \& Asensio, 1997; Aymí, 1999; de Juana \& Garcia, 2015). By analogy with what has been observed for cinereocapilla and feldegg (Ferlini, 2015; 2016), the increase in the presence in Western Africa could be a consequence of a western expansion of the breeding range of thunbergi, which should be further investigated. In Europe, reports in winter of isolated specimens have only occurred since 2006 in England, Sweden, and Norway.

\section{Wintering range of Motacilla flava iberiae (Fig. 9, Plate 6)}

Over the entire period covered by the study, the subspecies has been regularly present in Morocco. In this country, the apparent increase in both the number of reported individuals and the number of localities where the subspecies is present probably should be attributed to the increase of ornithologists who have frequented the area. The subspecies goes south to Southern Mali and Ivory Coast. In consideration of the most recent data and of the studies conducted by Wood (1975), it can be assumed that the individuals observed in Nigeria in the 1960s identified as iberiae, were specimens of the subspecies cinereocapilla. The actual wintering range in Western Africa appears to be significantly less extensive than previously indicated (Keith et al., 1992; Alström et al., 2003). In the $21^{\text {st }}$ century, the wintering of the subspecies iberiae has also been ascertained in Spain.

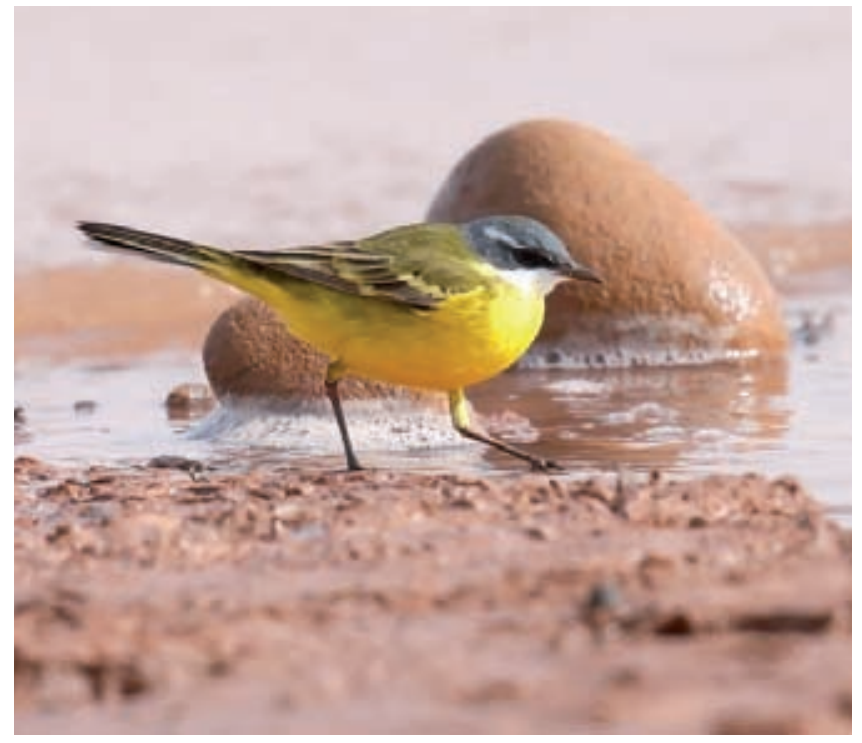

Fig. 9 - Motacilla flava iberiae, March 2017, Mansour Reservoir, Morocco. / Motacilla flava iberiae, marzo 2017, invaso di Mansour, Marocco. (Photo / Foto: Tony Davison, www.tonydavisonphotography. com).

\section{Wintering range of Motacilla flava cinereocapilla (Plate 7)}

The winter range of cinereocapilla has been very controversial over time as can be guessed from the unlikely situation described by Chapin (1953) relating to the period 1910-1946:

«Winters quarters are apparently from the upper Niger east to Lado, Entebbe on the north shore of lake Victoria, and Abyssinia. There is no actual record from Congo, but an occasional winter wanderer may be espected in the Upper Uele or near Lake Albert.».

The critical element in this case was the possible confusion with the subspecies pygmaea and thunbergi. The reports that have occurred over time with reference to the eastern part of Africa (from Sudan to Malawi) are in fact attributable to the latter subspecies (Pearson, 1972; Carswell, 1986). Even the recent single report concerning the Aswan Governatorate (Egypt) could be the result of confusion with pygmaea. Compared to what is indicated by the most up-to-date reference texts (Morocco, from Mali to Nigeria, east to Lake Chad) (Keith et al., 1992; Alström et al., 2003; Borrow \& Demey, 2008), it seems that the subspecies has expanded and is also well established in Senegal and Gambia, an area for which sporadic reports existed at the end of the $19^{\text {th }}$ century (Shelley, 1900 ) and in the first decades of the $20^{\text {th }}$ century (Bannerman, 1936). Louette \& Prévost (1987) have expressed doubts about the presence of cinereocapilla in Cameroon, however I believe that the observations are plausible given the certain and abundant presence at Lake Chad and the reports of the subspecies in more southern areas than to the latter during the migratory period. Completely new compared to the past is the winter presence of the subspecies in Europe: certainly in Italy, probably in Spain, and exceptionally in Germany (possible confusion with thunbergi?). 
Plate 6 - Wintering range of / Areale di svernamento di Motacilla flava iberiae.

Single ind. $\quad$ 2-10 ind. $\quad$ 11-100 ind. 101-1,000 ind.

$1,001-10,000$ ind.

Over 10,000 ind.

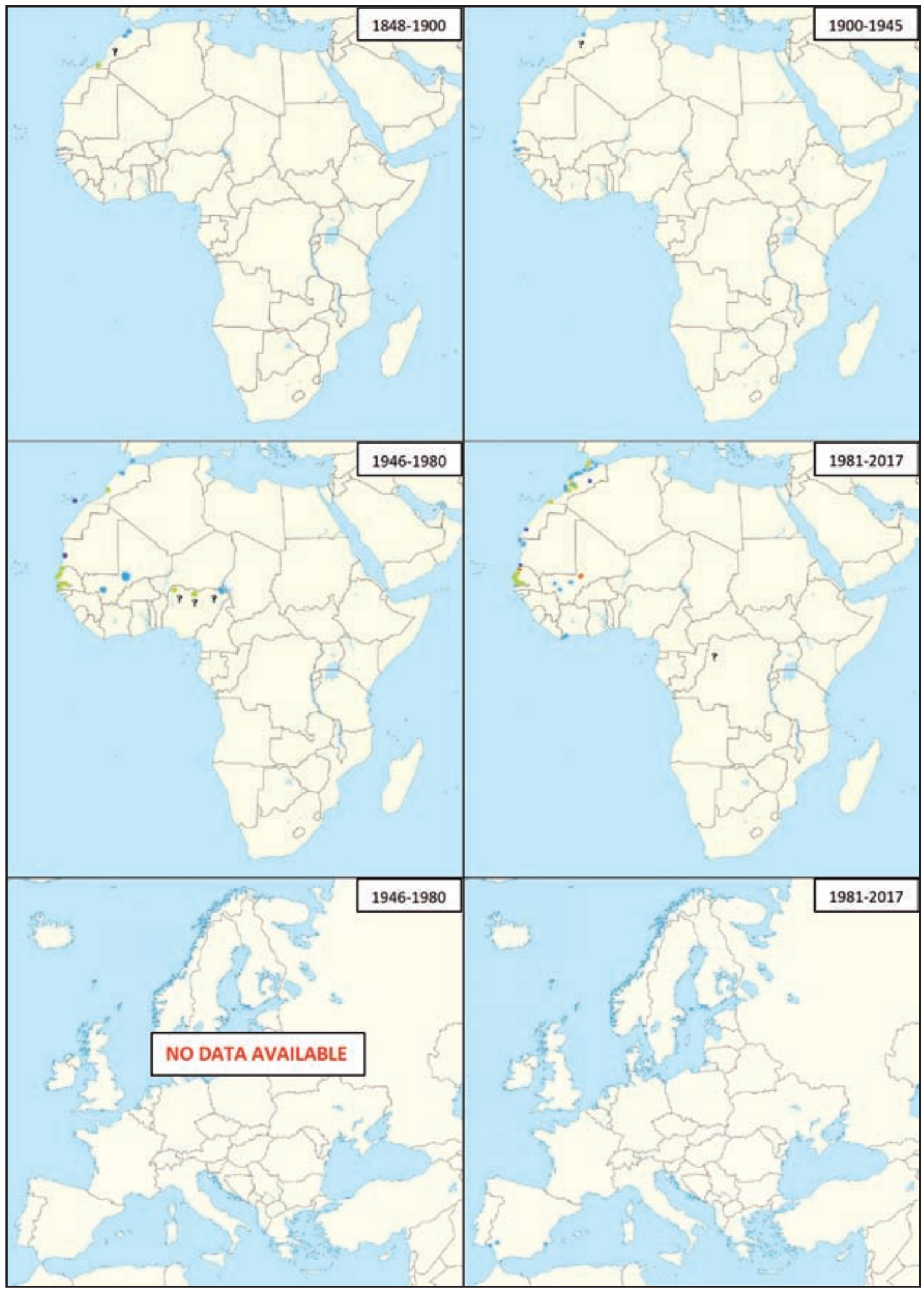


Plate 7 - Wintering range of / Areale di svernamento di Motacilla flava cinereocapilla.

\begin{tabular}{|l|l|l|l|l|l|l} 
Single ind. & 2-10 ind. & $11-100$ ind. & 101-1,000 ind. & $1,001-10,000$ ind. & Over 10,000 ind.
\end{tabular}

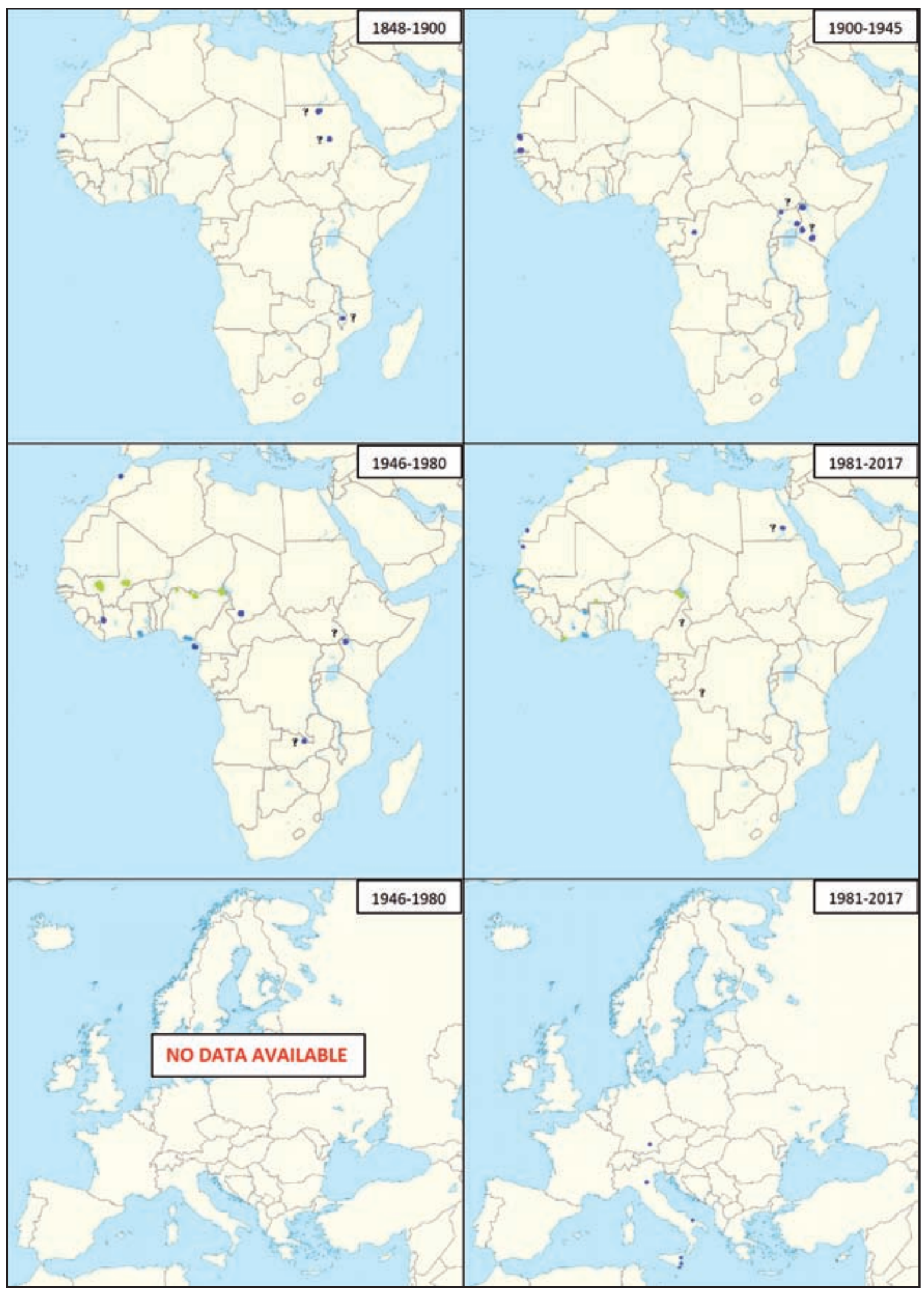




\section{Wintering range of Motacilla flava pygmaea (Fig. 10, Plate 8)}

During the entire study period, the subspecies had a concentrated presence along the River Nile (from Lake Nasser to the river delta) and some Egyptian wetlands (e.g. in the Wadi el Natrun Valley and Lake Qarun). The subspecies is substantially sedentary, even if it makes movements within the area previously outlined. The observations of individuals outside of Egypt are quite exceptional: a specimen was reported in Sudan in 1908 (Goodman \& Atta, 1987) and some individuals were in Israel (4 reports until 2011) (Porter \& Aspinall, 2010; IRDC, 2015).

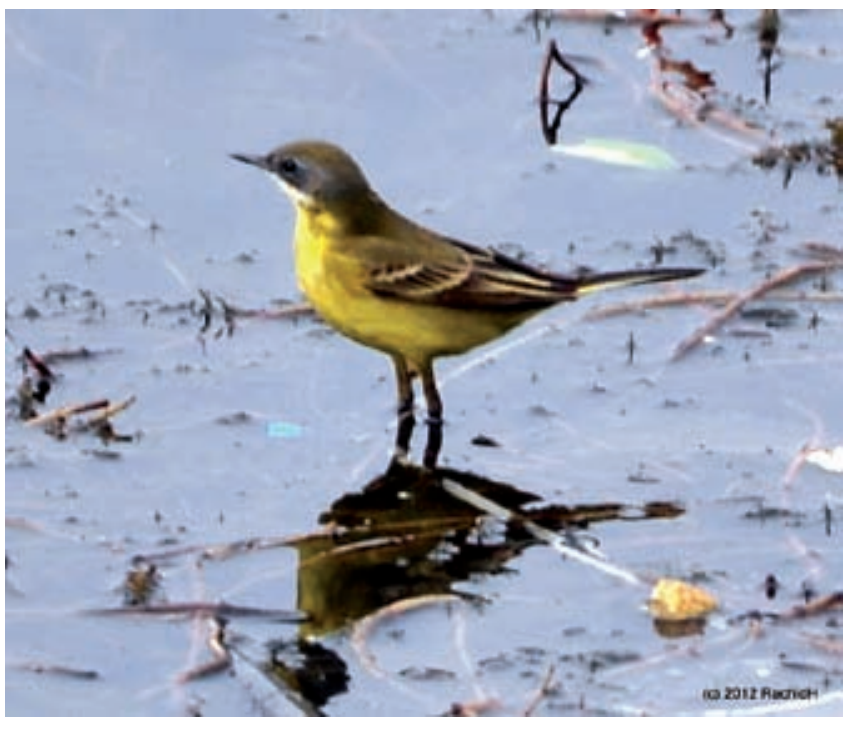

Fig. 10 - Motacilla flava pygmaea, 14 ${ }^{\text {th }}$ January 2012, eastern bank of the river Nile near Cairo, Egypt. / Motacilla flava pygmaea, 14 gennaio 2012, riva orientale del fiume Nilo vicino a Il Cairo, Egitto. (Photo / Foto: Rachid H., CC BY-NC 2.0, https://www.flickr.com/photos/ rachidh/6840295687/in/photostream/, "Egyptian Yellow Wagtail Motacilla flava - Bergeronnette printanière - on the eastern bank of the river Nile near Cairo").

\section{Wintering range of Motacilla flava feldegg (Fig. 11, Plate 9)}

Until 1945, the subspecies was predominantly concentrated in the eastern part of Africa between Sudan and Kenya; further south, the presence was scarce or accidental. In South Africa, there was only one presence during the $19^{\text {th }}$ century (Ayres, 1871; Sharpe, 1871), and there were no others until the 1960s (Clancey, 1966; Winterbottom, 1968). In the second half of the twentieth century, the situation described above for Eastern Africa was confirmed, but starting from the 1960s, the subspecies was also frequent in Southern Chad (Hopson, 1965), common along the shores of Lake Chad (Dowsett, 1969), abundant in the area of Kano (Nigeria) (Ebbutt et al., 1964; Fry, 1965a; 1965b; Sharland, 1964; 1965; 1966; 1967a; 1968; Moreau, 1972), and present in the eastern part of the Nigerian Atlantic coast (Wells \& Walsh, 1969). In the following decade, sporadic reports were also reported in Mali (Delta and Plateau Dogon)

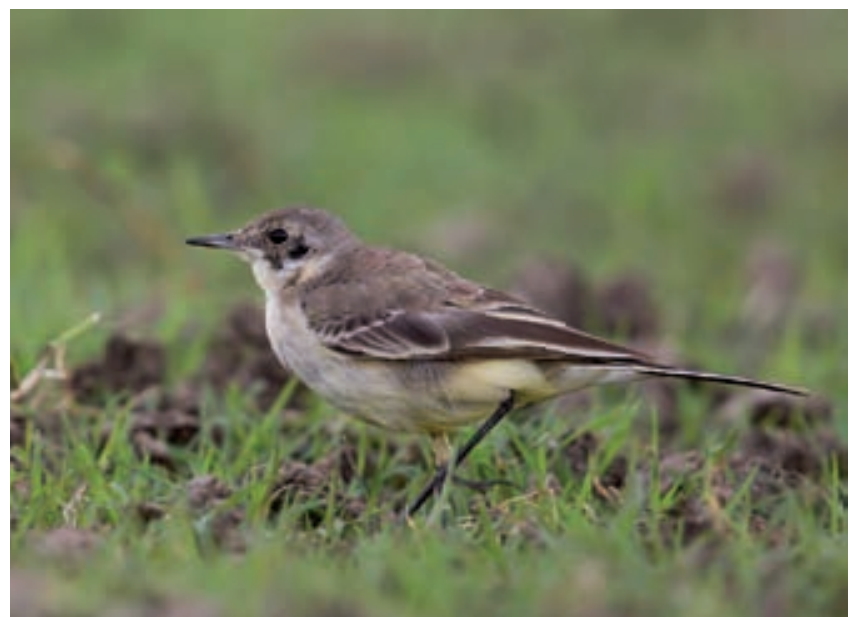

Fig. 11 - Motacilla flava feldegg (first winter), $19^{\text {th }}$ December 2012, Lake Ziway, Ethiopia. / Motacilla flava feldegg (primo inverno), 19 dicembre 2012, lago Zuai, Etiopia. (Photo / Foto: Thomas Varto Nielsen).

(Lamarche, 1981). In the period 1981-2017, the distribution was confirmed mainly in the central-eastern part of Africa, but there was also an expansion towards the west for the subspecies in the sub-Saharan belt up to a few specimens in Sierra Leone, Gambia, and Mauritania (Ward \& Ward, 2004; Observation.org, 2017). The wintering of some individuals in Western Africa from the late 1980s has established a new migratory route that brings the subspecies to the reproductive quarters of central Europe through Spain and Southern France (Ferlini, 2016). Starting from the beginning of the $21^{\text {st }}$ century, the expansion of the wintering area towards the north appears to be completely new, with regular presences in Egypt along the River Nile. In Europe, the only winter reports were recorded in Italy, and until now, limited to Sicily. The occasional presence of individuals is confirmed also in the south up to South Africa. Over time, the authors agreed that feldegg is more often associated with water than the other subspecies (Chapin, 1953; Britton, 1980; Carswell, 1986; Nikolaus, 1989).

\section{Wintering range of Motacilla flava beema (Fig. 12, Plate 10)}

For the beema subspecies I did not find any data concerning the $19^{\text {th }}$ century. Until 1980 , reports were scarce, mainly concerning isolated individuals, concentrated in the equatorial area of Eastern Africa (Kenya, Uganda, Burundi, Democratic Republic of Congo), with sporadic presences in Zambia. Also in the period 1981-2017, this distribution was confirmed with accidental presenses in South Africa, as well as the novelty constituted by reporting important concentrations in Ethiopia (this data deserves further confirmation). The distribution in Eastern Africa, as for the other eastern subspecies (lutea and leucocephala), is certainly motivated by the use of the well-known Great Rift Valley Migration Flyway which stretches over 7,000 km from the Taurus Mountains in Turkey to the Zambezi River in Mozambique (Leshem et al., 2006). 
Plate 8 - Wintering range of / Areale di svernamento di Motacilla flava pygmaea.

\begin{tabular}{|l|l|l|l|l|l|l} 
Single ind. & 2-10 ind. & $11-100$ ind. & & $101-1,000$ ind. & $1,001-10,000$ ind. & Over 10,000 ind.
\end{tabular}

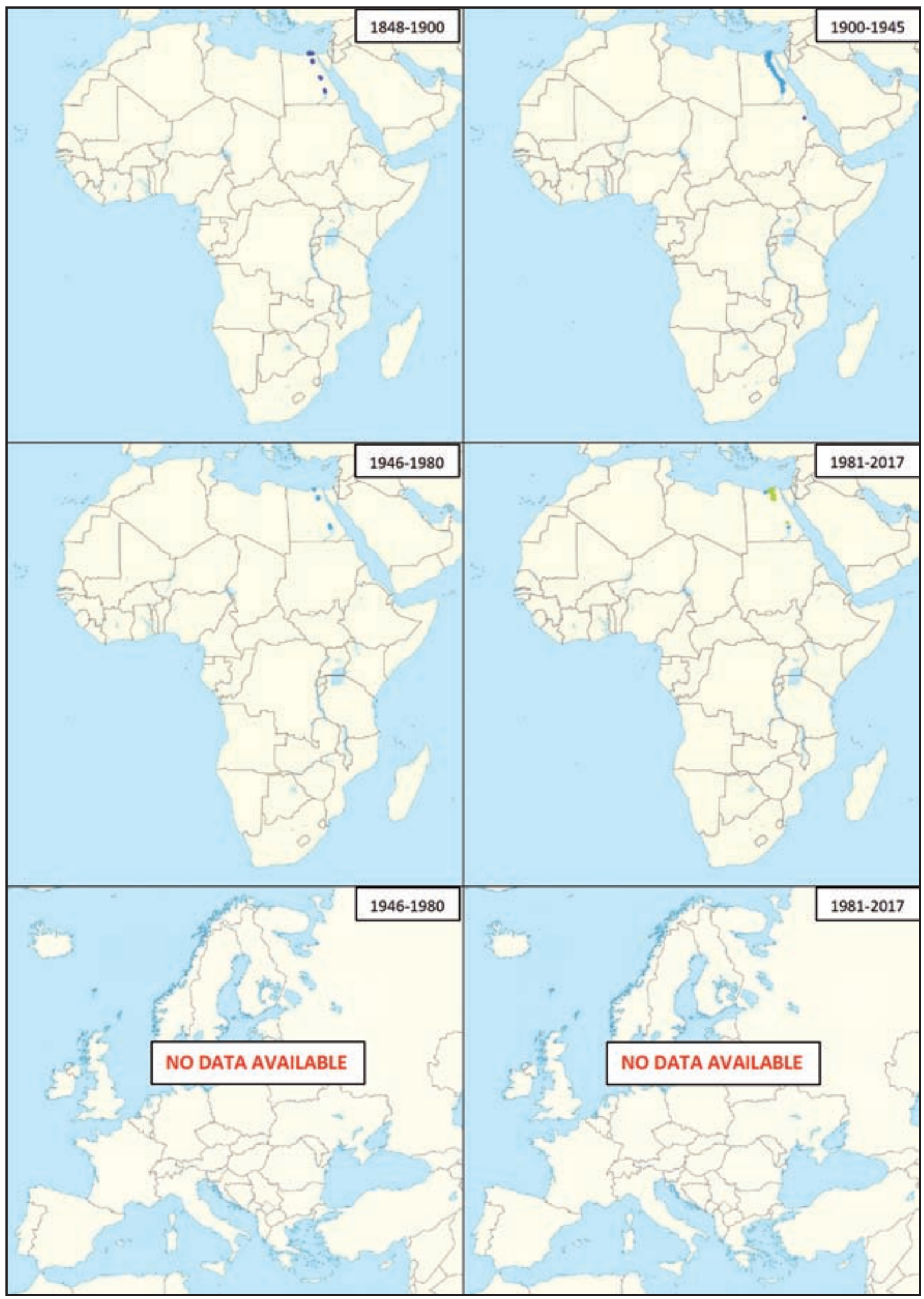


Plate 9 - Wintering range of / Areale di svernamento di Motacilla flava feldegg.

\begin{tabular}{l|l|l|l|l} 
Single ind. & 2-10 ind. & $11-100$ ind \\
\hline
\end{tabular} 101-1,000 ind. 1,001-10,000 ind.

Over 10,000 ind.

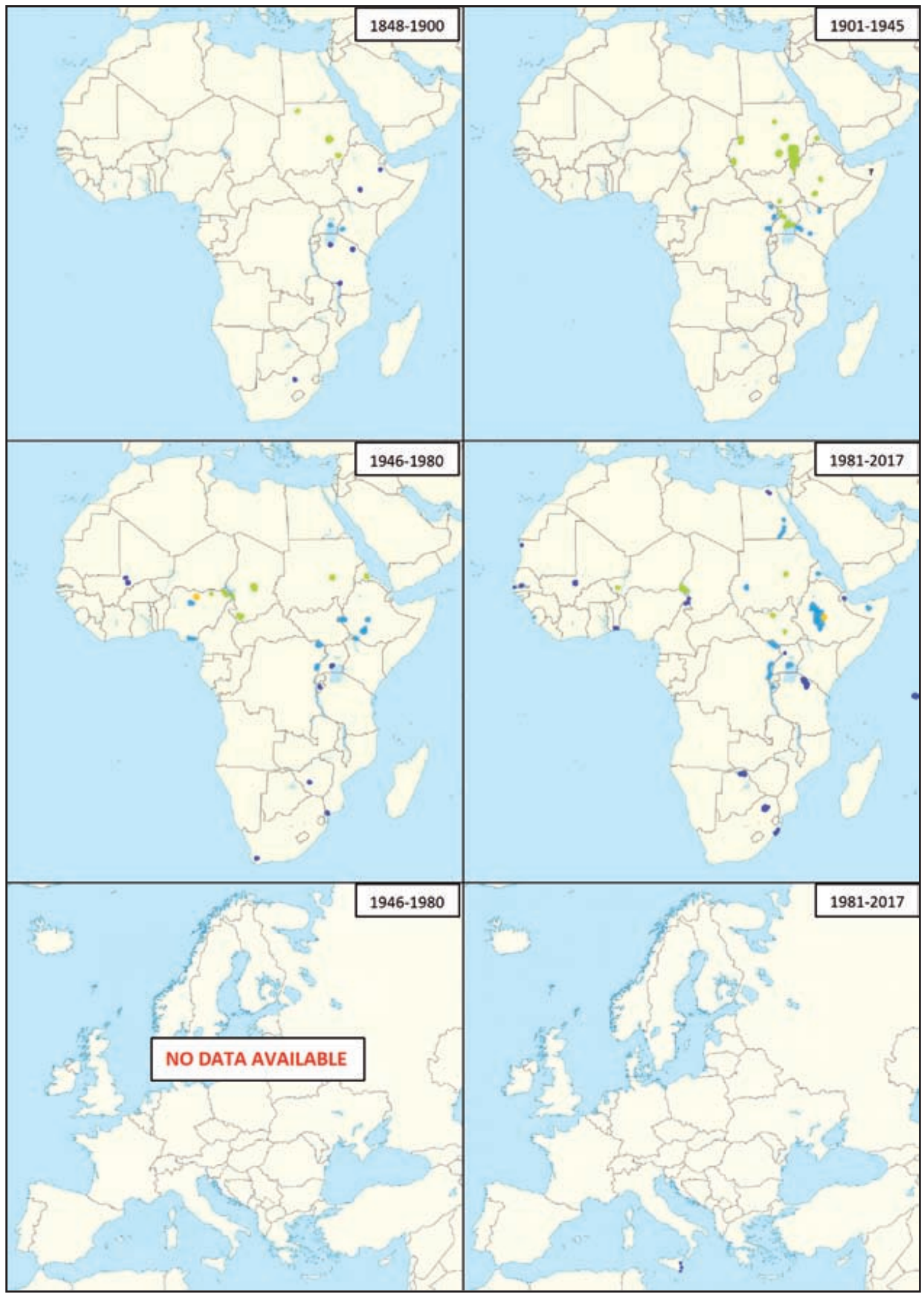


Plate 10 - Wintering range of / Areale di svernamento di Motacilla flava beema.

\begin{tabular}{|l|l|l|l|l|l|l} 
Single ind. & 2-10 ind. & $11-100$ ind. & $101-1,000$ ind. & $1,001-10,000$ ind. & Over 10,000 ind.
\end{tabular}

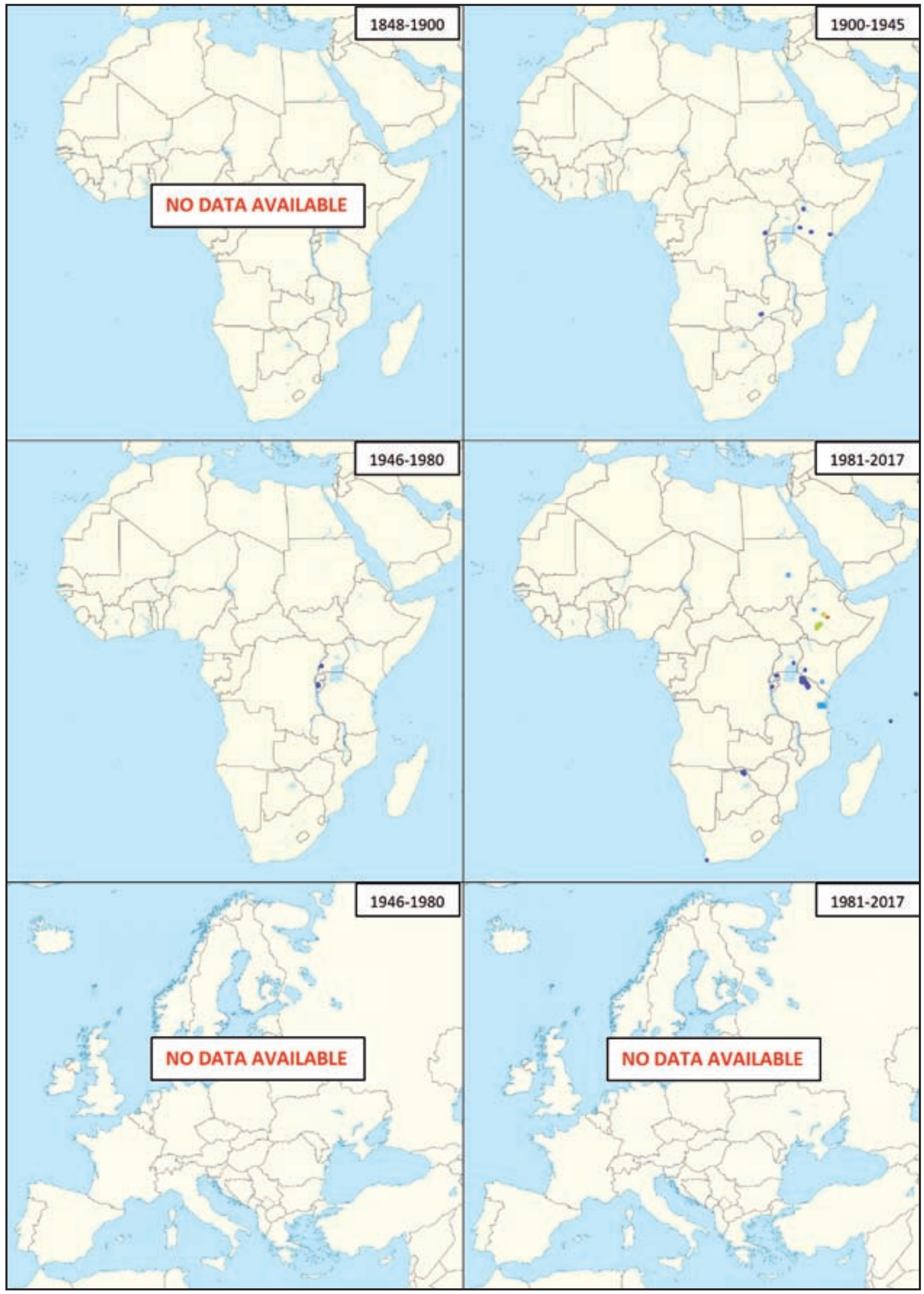




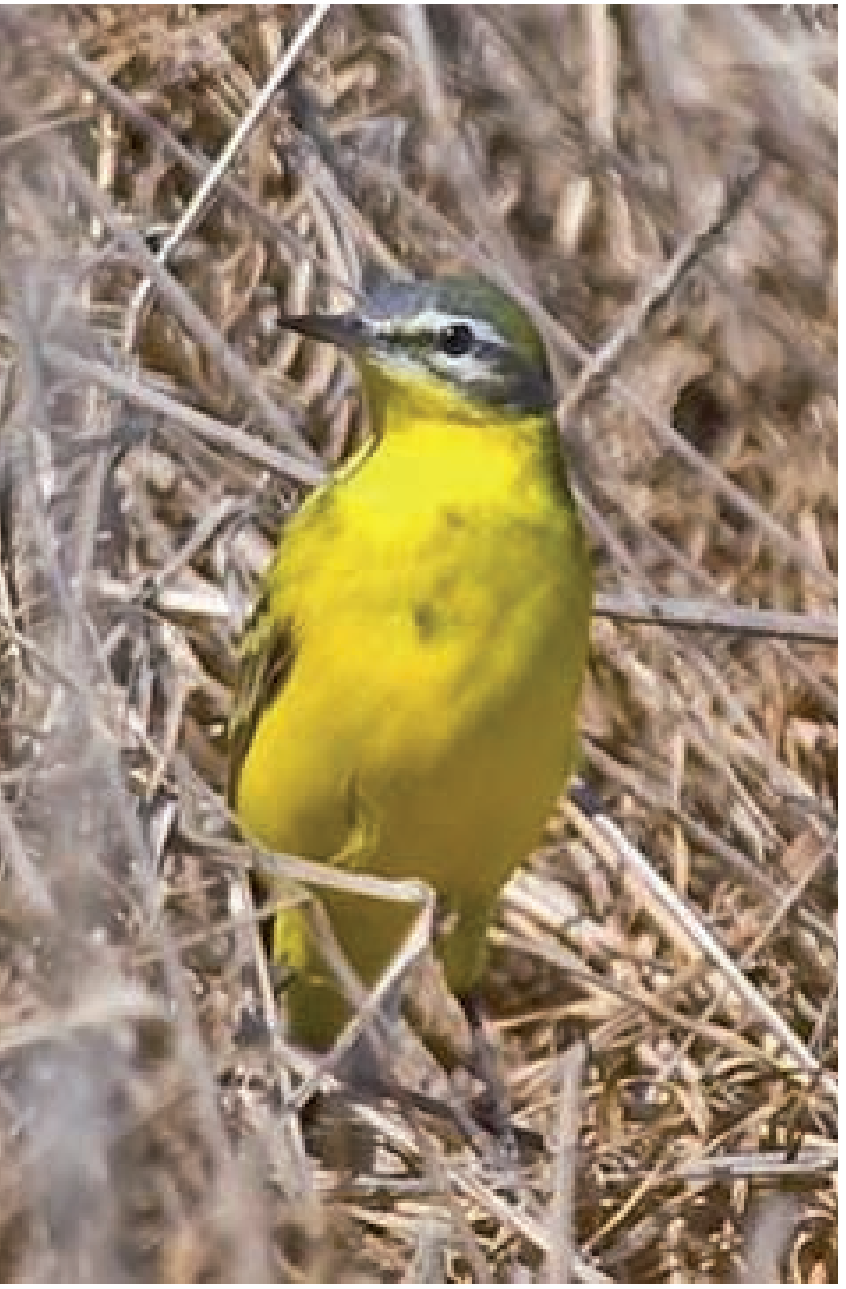

Fig. 12 - Motacilla flava beema, $11^{\text {th }}$ March 2010, Strandfontein, Cape Town, South Africa. / Motacilla flava beema, 11 marzo 2010, Strandfontein, Città del Capo, Sud Africa. (Photo / Foto: Patrick Cardwell, www.avianleisure.com).

\section{Wintering range of Motacilla flava lutea (Fig. 13, Plate 11)}

The subspecies lutea remained permanently present in the eastern part of Africa throughout the period of study, reaching to the north the southern part of Sudan and to the south the Eastern Cape Province (South Africa). The greatest permanent abundance was recorded in Tanzania and Kenya. In this last country, ringing activity was particularly intense, thus allowing information on the origin of the wintering individuals to be obtained. On $23^{\text {rd }}$ August 1969, an adult male was collected in Raveskii (Republic of Bashkortostan, Russia) after being ringed on $8^{\text {th }}$ December 1968 in Kariobangi (Nairobi, Kenya); in July 1974, an adult male was captured in Novotulka (Saratov, Russia) after being ringed in the suburbs of Nairobi (Kenya) on $18^{\text {th }}$ February 1969 at a distance of 5,884 km; another male ringed in Kariobangi (Nairobi, Kenya) on $10^{\text {th }}$ October 1972 was captured in Ufa (Republic of Bashkortostan, Russia) on $24^{\text {th }}$ June 1974 at a distance of 6,473 km; an individual in the second year was ringed at Nairobi (Kenya) on $2^{\text {nd }}$ February 1975 and returned to Engels (Saratov, Russia) on $2^{\text {nd }}$ May 1975

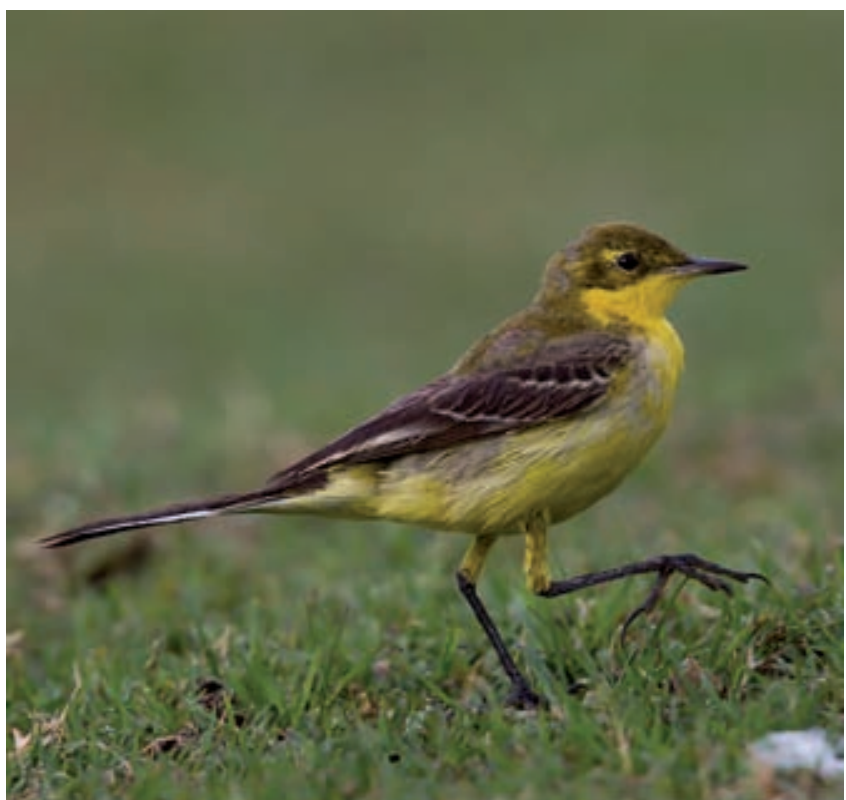

Fig. 13 - Motacilla flava lutea, $1^{\text {th }}$ December 2012, Lake Ziway, Ethiopia. / Motacilla flava lutea, 19 dicembre 2012, lago Zuai, Etiopia. (Photo / Foto: Thomas Varto Nielsen).

after traveling 5,931 km (Backhurst, 1970; 1977). The subspecies reaches the African wintering range (as well as those of the Arabian Peninsula) probably following the Volga Valley up to the Caspian Sea shores, then crossing the bottleneck constituted by the Caucasian area (Backhurst, 1974; 1977; Millen, 2017; Observation. org, 2017), after which the migratory flow widens as can be guessed from the reports, to the north, in Greece and in the Eastern Mediterranean islands (Kos, Crete and Cyprus) (Ferlini, 1994; Hellenic Rarities Committee, 2010; Porter \& Aspinall, 2010; RAF Ornithological Society, 2016; Observation.org, 2017), and to the south, in Saudi Arabia and Oman (Salalah) (Observation.org, 2017). The post-reproductive migratory movements can begin as early as August, as can be deduced from the observation of three specimens (two adults and one young) present on $16^{\text {th }}$ August 1993 in a fallow in Kamari on the island of Kos (Greece) (Ferlini, 1994). Also during the pre-breeding migration, the flow towards northeast is dispersed on a broad front that touches Greece (island of Lèsbos), Turkey (Gögsu Delta, Gaziantep), Israel (Eilat), Saudi Arabia (Dhahran, Taif), Kuwait, and Qatar, up to the south coast of the Caspian Sea in Iranian territory (Backhurst, 1974; Observation.org, 2017). In the ascent to the northeast to reach the breading range, the flow is again concentrated in the Caucasian area (Georgia, Armenia, Azerbaijan) (Observation.org, 2017). During the stay in Africa, lutea shows environmental preferences that vary radically from area to area; both in Sudan and in Congo it seems particularly linked, more than other subspecies, to wetlands and the banks of rivers (Macleay, 1960; Curry-Lindahl, 1965), while in Kenya, Tanzania, and Uganda it winters in drier areas (Wallace, 1955; Curry-Lindahl, 1965; Pearson, 1972; Britton, 1980; Carswell, 1986; Pearson \& Turner, 1986). 
Plate 11 - Wintering range of / Areale di svernamento di Motacilla flava lutea.

\begin{tabular}{|l|l|l|l|l|l|l} 
Single ind. & 2-10 ind. & $11-100$ ind. & $101-1,000$ ind. & $1,001-10,000$ ind. & Over 10,000 ind.
\end{tabular}

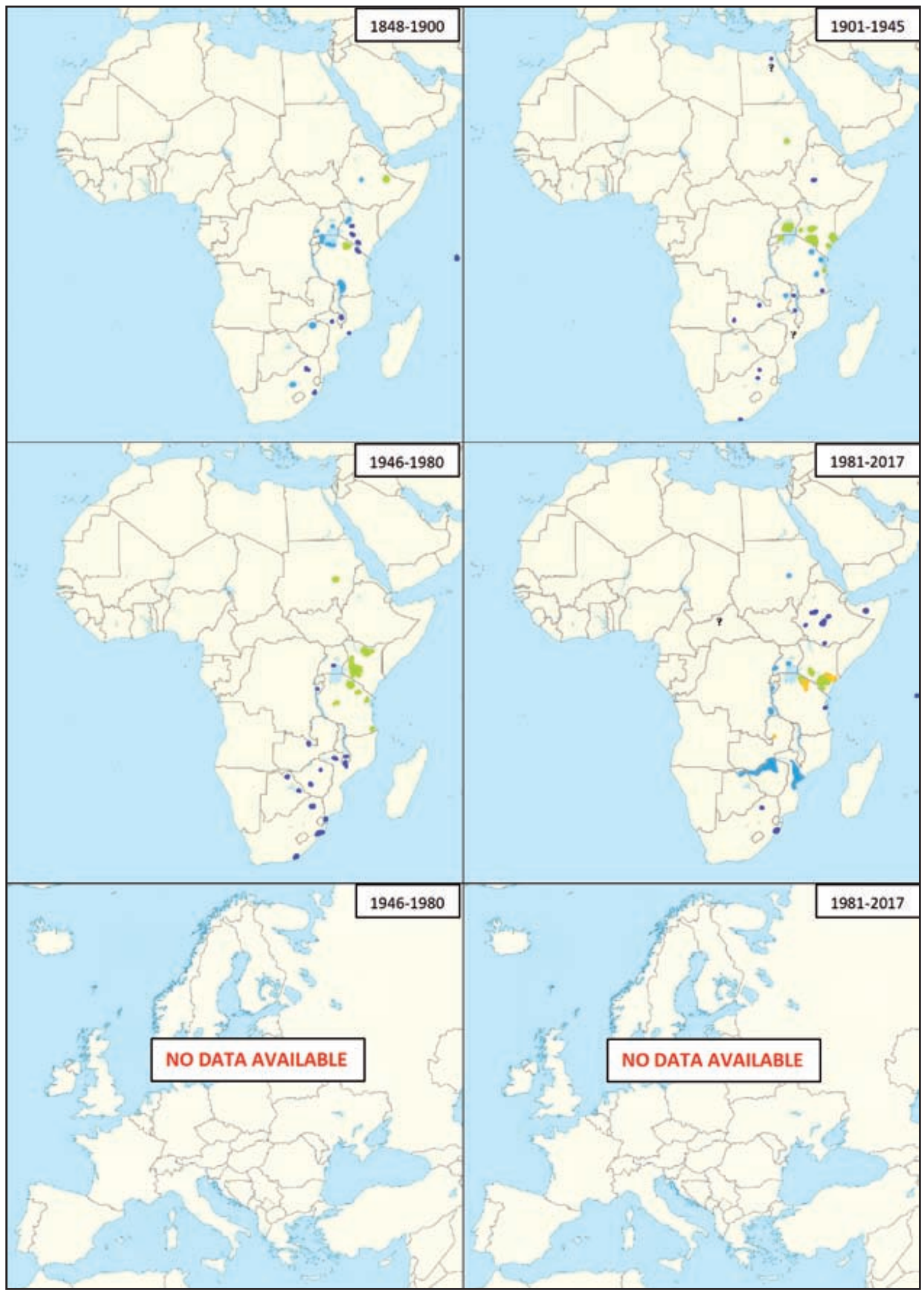




\section{Wintering range of Motacilla flava leucocephala (Fig. 14, Plate 12)}

There are no data on this subspecies in the $19^{\text {th }}$ century. Subsequently, the sporadic observations were concentrated in the equatorial area and, in particular, in Kenya (Nairobi County and Laikipia County), Uganda (Wakiso District), and Tanzania (Lake Manyara National Park). For Tanzania, Keith et al. (1992) also cited the locality of Arusha Chini (Moshi Rural District), but the date of the observation is not known. Further south, the subspecies was observed in 1947 in the Karonga District in Malawi and, on an unknown date, in Zambia (Kanyamwe in Feira) (Keith et al., 1992). The birds from Mongolia that reached Malawi or Zambia have traveled over $12,500 \mathrm{~km}$. The identification of this subspecies outside the reproductive range requires a certain caution, since birds resembling leucocephala may be aberrant or very pale beema, but these usually conserve darkish looking lores (Wassink, 2015; 2016); they could even be anomalous individuals of the subspecies flava (Meinertzhagen, 1956), hybrids of $M$. f. beema with M. f. leucocephala (characteristic e.g. of Tuva Republic, Russia) (Redkin, 2011) or first generation hybrids of M. f. flava with M.f. lutea (Redkin, 2013). Since the subspecies breeds around the Great Lakes Basin of Western Mongolia (Bräunlich, 2002), the few individuals that reach the African continent must cross Central Asia and the Middle East; rare observations are made in Southern and Southeastern Kazakhstan (spring migration from $17^{\text {th }}$ April to $19^{\text {th }}$ May and autumn migration in September, but one was ringed at Lake Alakol on $8^{\text {th }}$ July 1981) (Gavrilov \& Gavrilov, 2005; Wassink \& Oreel, 2008; Wassink, 2009), Azerbaijan (only one record on $12^{\text {th }}$ April 2012) (Heiss \& Eidam, 2015), Iran (South Khorasan

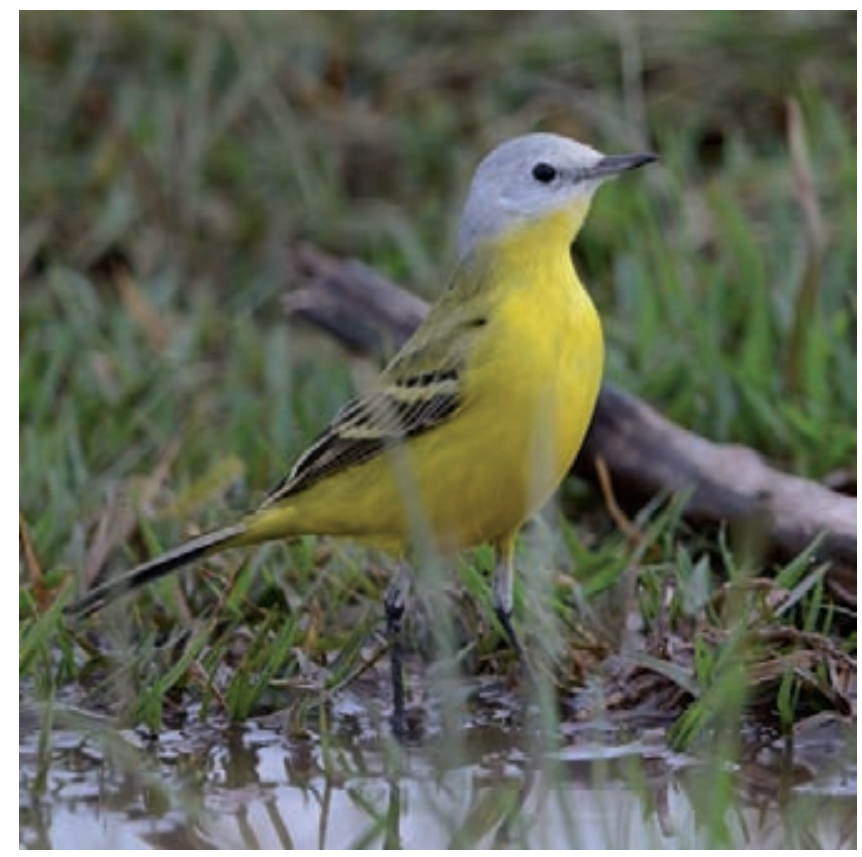

Fig. 14 - Motacilla flava leucocephala, $5^{\text {th }}$ April 2015, Ngorongoro Crater Rim, Tanzania. / Motacilla flava leucocephala, 5 aprile 2015, cratere di Ngorongoro, Tanzania. (Photo / Foto: Per Holmen, www. holmen-birding-safari.com). and Parapamis in the past and one record in Golestan Province on $7^{\text {th }}$ April 2017), Turkey (only one record on $25^{\text {th }}$ April 2011), Israel, Kuwait, United Arab Emirates, and Oman (records on Spring 1991 and 2012) (Zarudny, 1911; Al-Sirhan, 2009; Porter \& Aspinall, 2010; Kirwan et al., 2014; Blair et al., 2017; Eriksen \& Porter, 2017; Iran Bird Records Committee, 2017). Bernis (1970) reported two subjects observed in Greece in May, but without other details. For this subspecies, I consider further studies necessary because I cannot exclude that many of the whiteheaded western yellow wagtails observed in Africa and along the migratory routes that connect it to Asia are not true leucocephala.

\section{CONCLUSIONS}

\section{Evolution of wintering range of Motacilla flava in Africa and Europe}

The data collected from 1848 to 2017 show that the wintering range of the western yellow wagtail Motacilla flava remained substantially stable in Africa, with a probable quantitative reduction in South Africa, perhaps linked to the overall decline of the species in the European breeding range. Since the mid-1980s, the wintering area of the species has significantly expanded to the north, occupying areas in Europe with average temperatures in January above $0{ }^{\circ} \mathrm{C}$. The northward expansion of the area used for wintering by the western yellow wagtail is consistent with the similar trend shown by other trans-Saharan migrant species, especially non-passerines, which are increasingly present in winter north of the Sahara (Morganti \& Pulido, 2012; Morganti et al., 2014). Taking into account the current climate changes with the increase in minimum winter temperatures in Europe (EEA, 2009), this choice is a competitive advantage, since it allows birds to reduce the distances traveled during migration and, consequently, to decrease the connected energy cost, as well as advancing physiological development in response to exposure to photoperiods from northern latitudes (Coppack \& Both, 2002; Coppack \& Pulido, 2004; Newton, 2008).

The current distribution of the species during the boreal winter can be summarized as follows: in Europe, it is scarce but regular in the southwestern countries (Spain, Portugal, and Italy) and present in a more occasional and limited way in Greece, the Southeastern Mediterranean islands (Malta, Crete, Cyprus), Western Europe (France, Switzerland, Austria, Germany, United Kingdom), and Scandinavia. In Northern Africa, it is common in Morocco and Egypt, and it is present in small numbers in Algeria, Tunisia, and Libya (although there may be an underestimation of the phenomenon due to the lesser presence of ornithologists). It overwinters locally in abundance from the Sahel up to the wetlands of Botswana; it is regular, but scarce, further south to Cape Town and even more occasional in Angola and Namibia. It is scarcely present in the Malagasy Region. It is absent or very localized in African climatic zones classified as "subtropical high-continental arid" (Lauer \& Frankenberg, 1988) (Fig. 15). 
Plate 12 - Wintering range of / Areale di svernamento di Motacilla flava leucocephala.

\begin{tabular}{|l|l|l|l|l|l|l} 
Single ind. & 2-10 ind. & $11-100$ ind. & $101-1,000$ ind. & $1,001-10,000$ ind. & Over 10,000 ind.
\end{tabular}

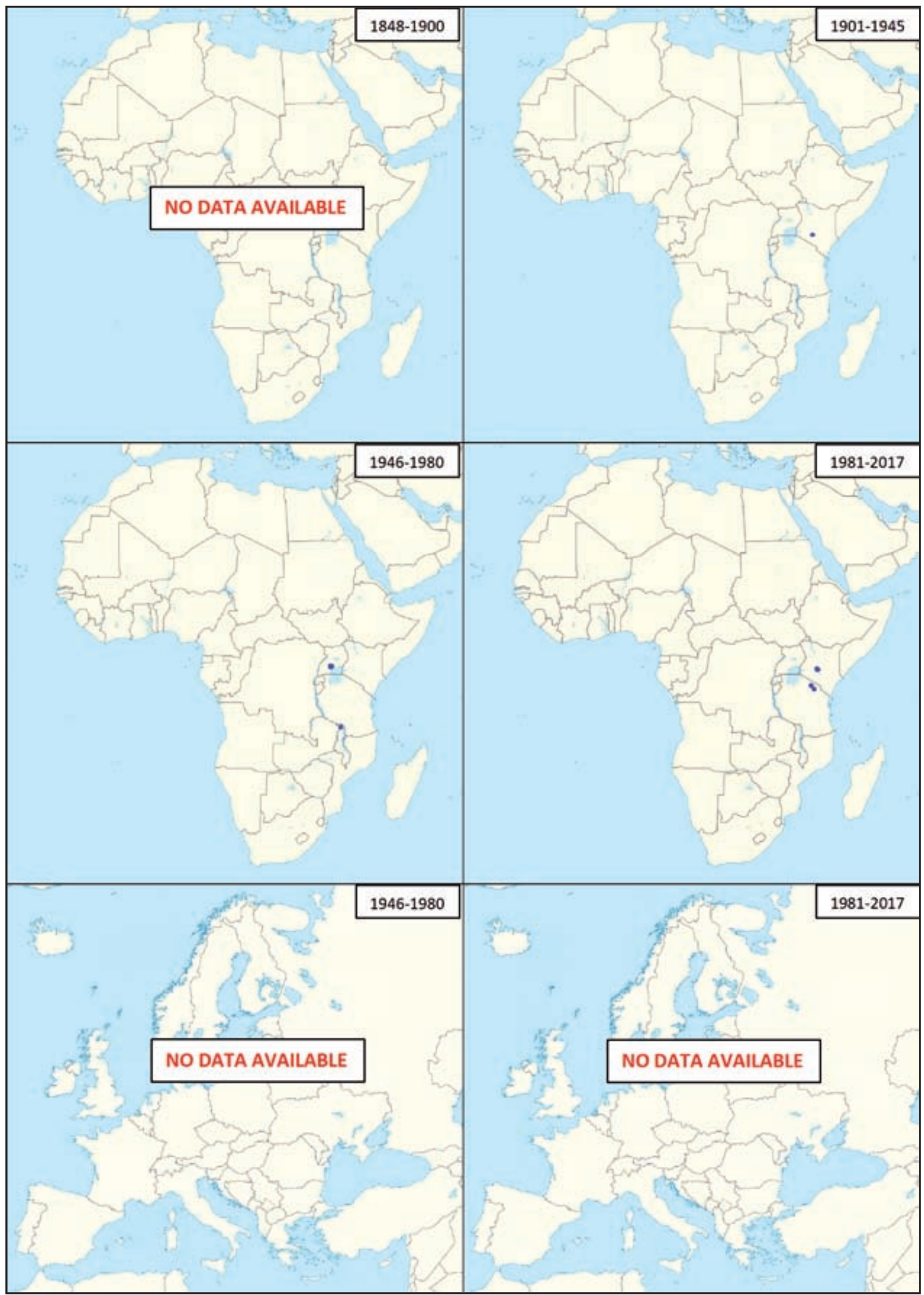




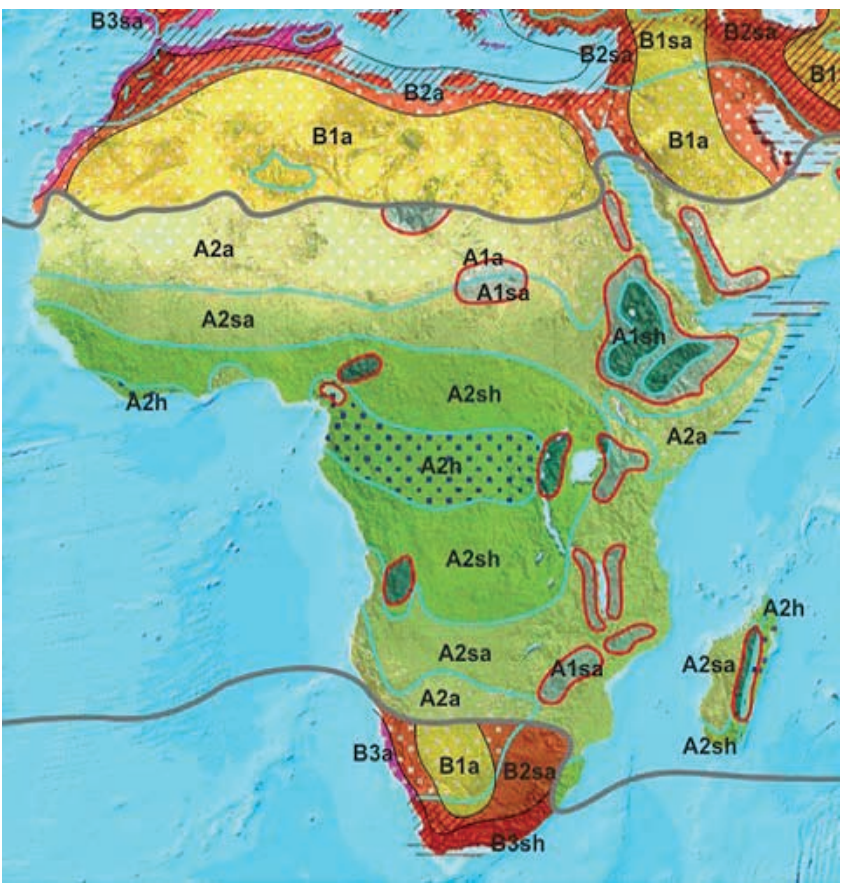

Fig. 15 - Classification of African climate zones based on natural vegetation Climate Zones. / Classificazione delle zone climatiche africane basate sulla vegetazione naturale. A) tropical / tropicale. B) subtropical / subtropicale. $\mathrm{C})$ temperate $(\mathrm{I}=$ moderately warm, $\mathrm{II}=$ cold $)$ / temperato $(\mathrm{I}=$ moderatamente caldo, $\mathrm{II}=$ freddo). $\mathrm{D})$ polar regions. $/$ regioni polari. Subclassification of the tropical climate zone. / Sottoclassificazione della zona climatica tropicale. 1) cold tropical / freddo tropicale; 2) warm tropical / caldo tropicale. Subclassification of other climate zones. / Sottoclassificazione di altre zone climatiche. 1) high-continental / fortemente continentale, 2) continental / continentale, 3 )= maritime / marittimo. Water household. / Livello di umidità: a) arid (0-2 rainy months) / = arida (0-2 mesi piovosi); sa) semi-arid (3-5 rainy months) / semi-arida (3-5 mesi piovosi); sh) semi-humid (6-9 rainy months) / semi-umida (6-9 giorni piovosi); h) humid (10-12 rainy months) / umida (10-12 mesi piovosi). (Source / Fonte: Lauer \& Frankenberg, 1988).

Analyzing the situation in Africa in terms of subspecies, the main changes for the wintering ranges, compared to what was known in the past, can be summarized as follows:

Increased presence of the subspecies flava in Egypt since the 1970s.

Less amplitude of the winter range of iberiae. In West Africa, the subspecies is confined between the Atlantic coast and the meridian $2^{\circ} \mathrm{W}$ instead of reaching the meridian $14^{\circ} \mathrm{E}$, as previously indicated.

Expansion of cinereocapilla towards the west with significant numerical presences in Senegal and Gambia.

Greater width of the wintering range of flavissima in Western Africa with possible presences also in Nigeria and Cameroon. The presence of a minority migratory route is hypothesized for the subspecies, which passes through the central Mediterranean more intensely in spring.

Increasing presences of thunbergi in the countries bordering the Gulf of Guinea that extended along the Atlantic coast in Gambia, Senegal, and with isolated individuals, Morocco.

West expansion of feldegg in the sub-Saharan belt and, from the beginning of the $21^{\text {st }}$ century, in Egypt along the River Nile.
Apparent numerical increases of beema in Ethiopia.

Substantial stability of the wintering ranges of pygmaea, lutea, and leucocephala.

For what has been reported above regarding the EuroAfrican area, the wintering ranges of the subspecies can be updated as follows:

Motacilla flava flava - In Europe, it is scarce in southwestern countries (Spain, Italy, and Portugal) and present more occasionally and locally in Greece, Cyprus, and the islands of the Southeastern Mediterranean, as well as Western Europe. In North Africa, there is a good numerical presence in Egypt, with small groups in Morocco and a very limited presence in Algeria, Tunisia, and Libya. It overwinters locally in abundance from the Sahel up to the wetlands of Botswana; it is regular, but scarce further south to Cape Town and even more occasional in Angola and Namibia. It occurs sporadically in the Malagasy Region.

Motacilla flava iberiae - It is present in small numbers in Spain and is widespread in Morocco, abundant in Senegal, Gambia, and, locally, in Southern Mali. It is less frequent further south to Ivory Coast.

Motacilla flava cinereocapilla - It is locally common in Western Africa, from Senegal to Nigeria and to Cameroon; present, but not common, in Morocco. It is scarce in Italy, probably present in Spain and accidental wintering in Germany (?).

Motacilla flava flavissima - It is widespread and locally common in Western Africa from Southern Mauritania to Burkina Faso and then south to the Atlantic coast. It is very scarce or occasional in Cameroon, Nigeria, and Central African Republic. It is uncommon in Morocco, and occasionally winters in Spain and the United Kingdom.

Motacilla flava thunbergi - It is locally abundant in the Sahel, from Senegal to Eritrea, in the south to the wetlands of Botswana and is scarce in South Africa. It is absent or very scarce along the Atlantic coast from Gabon to Namibia. It is common in Egypt along the River Nile, and scarce but regular, in Morocco. It is occasionally present in central and Northern Europe.

Motacilla flava pygmaea - It is concentrated along the River Nile (from Lake Nasser to the river delta) and in some Egyptian wetlands (e.g. Wadi el Natrun Valley and Lake Qarun).

Motacilla flava feldegg - It is widespread and locally common or very abundant from Egypt to the south to Northern Tanzania. It is scarce further south until reaching South Africa. To the west, it is common from Chad to Niger and very scarce south of the Sahara in the remaining countries of Western Africa until reaching Gambia. It occurs sporadically in the Malagasy Region and occasionallyin Southern Italy.

Motacilla flava beema - It is localy common in Ethiopia and widespread in the equatorial area of Eastern Africa (Kenya, Uganda, Burundi, Democratic Republic of Congo) with sporadic presences in Zambia. It is rare further south to South Africa and sporadically occurs in the Malagasy Region.

Motacilla flava lutea - It is widespread in Eastern Africa from Southern Sudan to the Eastern Cape Province (South Africa), is common and locally abundant in Tanza- 
nia and Kenya, and sporadically occurs in the Malagasy Region.

Motacilla flava leucocephala - It is occasional in the equatorial area, particularly in Kenya, Uganda, and Tanzania; in the past it reached Sudan, Malawi, and Zambia, but there are no recent reports.

\section{Conservation of the species in Africa and Europe}

The analysis carried out to define the priority areas for conservation of Palearctic passerines within sub-Saharan Africa has identified four geographical areas: (1) a west African area centered on Southern Mali that includes Southern Mauritania, Senegambia, Guinea-Bissau, Guinea, Northwestern Ivory Coast, and Burkina Faso; (2) an East African area centered on Eritrea that includes large parts of central Sudan, Northern Ethiopia, Djibouti, and Northwestern Somalia; (3) an area encompassing Uganda, Southwestern Kenya, and Northeastern Tanzania; and (4) an area centered on Northern Zimbabwe that includes Southwestern Zambia and small parts of Malawi, Mozambique, Northern Botswana, and Northern South Africa (Walther et al., 2010). As emerged from this study, it can be concluded that the priority areas defined as such are perfectly valid to protect also the western yellow wagtail specifically.

For the conservation of the species, the relationship between the western yellow wagtail and agriculture in Africa deserves attention. As already mentioned, the increased frequency of western yellow wagtails in cultivated areas, in particular those irrigated or flooded (rice paddies), is evident. This is a direct consequence of the increase in the presence in Africa of this environmental typology as a response to the growth of the population of the continent that drives the transformation of natural vegetation into farmland. Farming is the major source of food and income for poor rural households, whose numbers are growing despite urbanisation and overall economic growth (Bolwig et al., 2006). Farmland expansion and intensification are inevitably causing natural habitat degradation and act as a major acceleration in biodiversity loss (Sala et al., 2000; Bolwig et al., 2006). Between 1970 and 2000, sub-Saharan Africa's agriculturally used area increased by $4 \%$, fertilizer consumption almost tripled, and pesticide imports increased more than fivefold to treat about $16.3 \%$ of the cultivated area (Wolanski, 2012; Sheahan \& Barrett, 2017). In Africa, the predominant pesticide groups used are: insecticides (mainly organophosphates), fungicides, and herbicides. The total annual average amount of pesticides used per country is more important in North Africa and in the eastern flyway of African migratory birds from Egypt to South Africa via Kenya and Zimbabwe (Fig. 16) (Mullié \& Diop, 2001). Agricultural households across sub-Saharan Africa apply pesticides, fungicides, and herbicides far more frequently than is commonly acknowledged (Sheahan \& Barrett, 2014). Above all, this last aspect is worrying when considering the multiple effects that agrochemicals can have on birds: death, hormonal deregulations, breeding failures, deterioration of habitats due to herbicides or fertilizers, loss of food due to the impact of insecticides on invertebrates (Newton, 1998; Mitra et al., 2011). Of all those

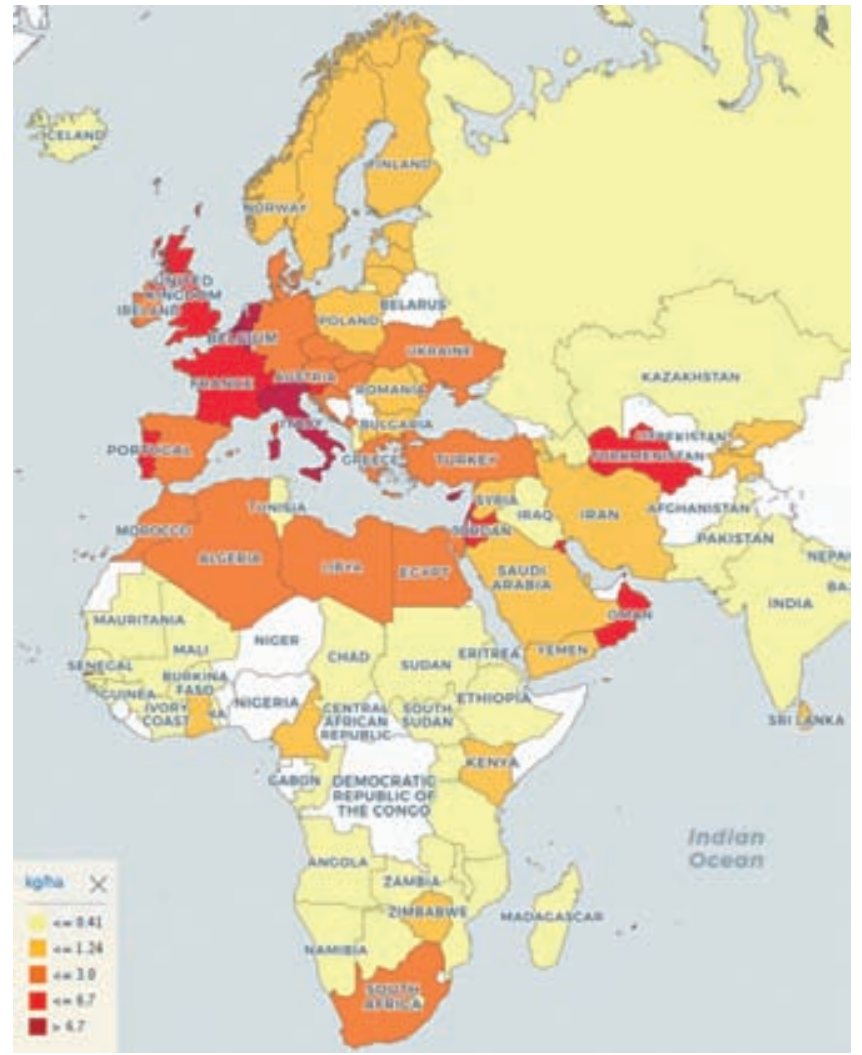

Fig. 16 - Average use of pesticides per area of cropland (arable land and permanent crops) at national levels in a time series from 1990 to 2015. / Uso medio di pesticidi per superficie coltivata (seminativi e colture permanenti) a livello nazionale dal 1990 al 2015. (Source / Fonte: FAO, 2017).

used, the most lethal agrochemical for birds is Carbofuran (2,3-dihydro-2,2-dimethylbenzofuran-7-yl methylcarbamate, also known as Furadan or Curater, the most toxic of the carbamate pesticides and the most widely abused in Africa), since in its granular form, a single grain may kill a bird: birds often eat numerous grains of the pesticide, mistaking them for seeds or pebbles and then die shortly thereafter (Mineau, 2005; Harrison, 2006; Parsons et al., 2010). Carbofuran is strictly controlled in the United States, Canada, and the European Union, but is still used in the rice paddies of Africa as pest control against locusts and birds (Ruelle, 1983; Odino \& Ogada, 2008; Parsons et al., 2010). As documented in Senegal, the western yellow wagtail is among the birds that die poisoned in the rice fields due to Carbofuran use (Mullié et al., 1991; Bogdanski et al., 2015).

In addition to being used to defend crops, Carbofuran is also intentionally used to kill wild animals for food and for traditional medicine (Ogada, 2014). Although, under national laws, it is illegal to hunt wildlife using poisons in $83 \%$ of African countries, it is a very widespread traditional practice. Recently, synthetic pesticides have replaced traditional plant- and animal-based poisons used to deliberately kill wildlife, and despite high levels of contamination, birds are coveted as bushmeat by consumers as a source of protein (Odino, 2011; Ogada, 2014). In the rice paddies in Western Kenya (Busia District), many species, 
both local and Palearctic migrants (e.g. Marsh sandpiper Tringa stagnatilis, common snipe Gallinago gallinago, black-tailed godwit Limosa limosa, ringed plover Charadrius hiaticula, wood sandpiper Tringa glareola, and western yellow wagtail), are caught by bait made up of termites laced with Carbofuran; in relation to the western yellow wagtail, it has been found that about $29 \%$ of the specimens present in the fields are killed by this hunting method (Odino, 2011). In 2010, every western yellow wagtail killed was sold for 5-10 Kenyan Shilling, equivalent to 0.04-0.08 Euro or 0.05-0.10 US Dollars (Odino, 2011). The western yellow wagtail is also an object of hunting as it is one of the 399 taxa (of which 107 Passeriformes) sold on skin-and-bone stalls as part of a general system of traditional African medicine (Williams et al., 2013; 2014). The fetish markets are particularly conspicuous in Ghana, Togo, Bénin, and Nigeria, and collectively they create a strong demand among the region's hunters and trappers (Cocker \& Mikkola, 2001; Williams et al., 2013). In Bénin, along with 7,039 other birds, eight specimens of western yellow wagtail were found on $20^{\text {th }}$ January 2002 in the Dantokpa market in Cotonou (Littoral Department), the biggest fetish market in Bénin and West Africa (Adjakpa et al., 2002). By analogy with the african pied wagtail Motacilla aguimp in Nigeria, it can be hypothesized that the power of giving security is attributed also to Motacilla flava (Nikolaus, 2001; 2011). In Central Africa, the wagtails are regarded as a good omens and messangers of peace (Daniels \& Stevens, 1903).

It is evident that the agricultural expansion and intensification and the resulting increase in the application of agrochemicals in Africa constitute an effective danger for the conservation of the western yellow wagtail. To remedy this, I hope that the recommendations clearly expressed by Ogada (2014) for the African continent can be appropriately adopted: banning pesticides, improving pesticide regulations and controlling distribution, better enforcement, stiffer penalties for offenders, increasing international support and awareness, and developing regional pesticide centers.

If the quality of the agrochemicals used in the African wintering range of the western yellow wagtail is most worrying for this region, in Western Europe, the use of chemical products in agriculture during the breeding season can also be a serious danger considering the high quantity used per unit area (kg/ha) (Fig. 16) (Bright et al., 2008; Goulson, 2014; Hallmann et al., 2014; Eyhorn et al., 2015). For the conservation of Motacilla flava and the other farmland birds, it is therefore necessary that cultivation methods that involve a reduction in the use of agrochemical products and encourage a more respectful use of natural resources and biodiversity (e.g. crop rotation, bio-control and natural pesticides, Integrated Pest Management, agroecology, organic agricolture) are adopted in Europe.

\section{Acknowledgements}

I heartedly thank Jeff Attaway, Nicola Baccetti, Massimo Biondi, John Bird, Giovanni Boano, Pierandrea Brichetti, the British Trust for Ornithology (specially Dawn Balmer and Neil Calbrade), Patrick Cardwell, Da- niel Edward Chamberlain, Giorgio Chiozzi, Andrea Corso, Giovanni Cumbro, Andrea Cusmano, Tony Davison, Andrea de Angelis, Pier Lisa Di Felice, Federico Fanesi, Giuseppe Fiorella, Claudio Fiorini, Maurizio Fraissinet, Jacques Franchimont, Fulvio Fraticelli, Armando Gariboldi, Dan Grec, Marcello Grussu, Per Holmen, Renzo Ientile, Ottavio Janni, Roberto Lardelli, Paul Leonard, Cristiano Liuzzi, Violetta Longoni, Klaus Malling Olsen, Michelangelo Morganti, the Museo di Storia Naturale of Milan, the Natural History Museum of London (specially Mark Adams and Matt Woodburn), Stefano Negri, Angelo Nitti, Vasiliki Orfanou, Cristian Panarisi, Bruno Portier, Nikos Probonas, Javier Pérez-Tris, the Sociedad Española de Ornitología (specially Blas Molina), Marc Ryckaert, Diego Rubolini, Angelo Scuderi, Giancarlo Torre, Thomas Varto Nielsen, and Ondřej Žváček for the information and materials they have kindly supplied. Special thanks go to the Editor and to the two anonymous referees for the critical revision of the text and for the valuable suggestions. I am also grateful to Kelsey Horvath for the English language revision.

\section{REFERENCES}

Adjakpa J. B., Tchabi A. \& Ogouvide F. T., 2002 - Oiseaux utilisés en pharmacopée traditionnelle au Bénin. Malimbus, 24: 1-14.

Allen B., 2016 - Animals in Religion: Devotion, Symbol and Ritual. Reaktion Books Ltd, London.

Al-Sirhan A. R., 2009 - The Kuwait Bird Report 2008. Kuwait Ornithological Rarities Committee (KORC).

Alström P., Mild K. \& Zetterstrom B., 2003 - Pipits and Wagtails of Europe, Asia and North America. Helm Identification Guides.

Alström P. \& Mild K., 2005 - Biologiska, fylogenetiska och monofyletiska arter - skillnader och likheter. Fåglar $i$ Uppland, 31: 12-21.

Archer G. \& Godman E. M., 1961 - The Birds of British Somaliland and the Gulf of Aden. Volume III. Oliver \& Boyd, Edinburgh.

Ash J. S. \& Miskell J. E., 1983 - Birds of Somalia: their habitat, status and distribution. Scopus, Special Supplement Number 1.

Ash J. \& Atkins J., 2009 - Birds of Ethiopia and Eritrea. An Atlas of Distribution. Christopher Helm, London, UK.

Austin R., 1942 - The Birds of South Africa. H.F. \& G. Witherby, Johannesburg.

Avifaunistische Kommission Baden-Württemberg, 2016 - Umlauf Juli 2016. <http://www.avikombw.de/bearbeitungsstand/umlaeufe2016/umlauf-juli-2016/> (retrieved in December 2017).

Aymí R., 1999 - Identification of adult male yellow wagtails in winter plumage in Western Europe. Dutch Birding, 21: 241-253.

Ayres T., 1871 - Additional Notes on Birds of the Territoris of the Trans-Vaal Republic. The Ibis, 1 (ser. 3): 147-157.

Backhurst G. C., 1970 - Bird Ringing Report 1968-1969. Journal of The East Africa Natural History Society and National Museum, 29: 16-26.

Backhurst G. C., 1974 - East afrincan bird ringing report 1972-73, 1973-74. Journal of The East Africa Natural History Society and National Museum, 146: 1-9.

Backhurst G. C., 1977 - East afrincan bird ringing report 1974-77. Journal of The East Africa Natural History Society and National Museum, 31 (163): 1-10.

Backhurst G. C., 1981 - Eastern African bird ringing report 1977-1981. Journal of The East Africa Natural History Society and National Museum, 174: 1-20.

Backhurst G. C., 1986 - East African Bird Report 1984. Scopus, 8 (5): 101-140.

Backhurst G. C., 1988 - Eastern African Ringing Report 1981-1987. Scopus, 12 (1/2): 1-52.

Bannerman D. A., 1936 - The birds of tropical West Africa with special reference to those of the Gambia, Sierra Leone, the Gold Coast and Nigeria. Vol. 4. The Crown Agent for the Colonies, London. 
Bell C. P., 1996 - Seasonality and Time Allocation as Causes of LeapFrog Migration in the Yellow Wagtail Motacilla flava. Journal of Avian Biology, 27 (4): 334. <DOI 10.2307/3677265>

Bell C. P., 2006 - Social interactions, moult and pre-migratory fattening among Yellow Wagtails Motacilla flava in the Nigerian Sahel. Malimbus, 28: 69-82.

Bennun L. A., 1991 - An avifaunal survey of the Trans-Mara Forest, Kenya. Scopus, 14: 61-72.

Benson C. W., 1940 - Further Notes on Nyasaland Birds (with particular reference to those of the Northern Province). Part III. The Ibis, 82 (4): 583-629.

Benson C. W., 1946 - Notes on the Birds of Southern Abyssinia. The Ibis, 88 (1): 25-48.

Bernis F., 1954 - Prontuario de la avifauna española. Ardeola, 1: 1185.

Bernis F., 1970 - Aves migradoras ibéricas, Vol. 6. Sociedad Española de Ornitología, Madrid.

Betser E., 2005 - An Ecosystem Approach to Restoring West African Drylands and Improving Rural Livelihoods through Agroforestrybased Land Management Interventions. West Africa Drylands Project. (http://outputs.worldagroforestry.org/cgi-bin/koha/opacdetail.pl?biblionumber=34521).

Biasutti M., Held I. M., Sobel A. H. \& Giannini A., 2008 - SST forcings and Sahel rainfall variability in simulations of the twentieth and twenty-first centuries. Journal of Climate, 21 (14): 34713486.

BirdForum, 2004 - Namibia. <http://www.birdforum.net/archive/index.php?t-21838.html $>$ (retrieved in December 2017).

BirdLife International, 2017 - Species factsheet: Motacilla flava. Downloaded from $<\mathrm{http} / /$ www.birdlife.org on 05/12/2017> (retrieved in December 2017)

Blair M., Steve P. \& Alenezi A. A., 2017 - The OSME Region List of Bird Taxa, Part C: Passerines. Version 4.1 August 2017. The Ornithological Society of the Middle East, the Caucasus and Central Asia.

Bogdanski A., Attwood S., DeClerck F., DeClerck R., Hadi B., Horgan F. G., Rutsaert P., Turmel M.-S., van Dis R. \& GemmillHerren B., 2015 - Shedding light on the invisible links within 'eco-agri-food-systems'. A narrative review of literature on how agricultural management can influence the positive and negative impacts of rice farming. FAO, unpublished project report for The Economics of Ecosystems and Biodiversity (TEEB) global initiative for Agriculture and Food. $<<$ https://www.researchgate.net/ publication/319997966_Shedding_light_on_the_invisible_links_ within 'eco-agri-food-systems' A narrative review_of literature_on_how_agricultural_management_can_influence_the positive and negative impacts of rice farming $>$

Bolwig S., Pomeroy D., Tushāe $\bar{H}$. \& Mushabe D., 2006 - Crops, trees, and birds: Biodiversity change under agricultural intensification in Uganda's farmed Landscapes in Geografisk Tidsskrift. Danish Journal of Geography, 106 (2): 115-130.

Borrow N. \& Demey R., 2008 - Birds of Western Africa. Christopher Helm, London.

Borrow N. \& Demey R., 2011 - Birds of Senegal and The Gambia. Christopher Helm, London.

Bos D., Grigoras I. \& Ndiaye A., 2006 - Land cover and avian biodiversity in rice fields and mangroves of West Africa. A\&W-report 824. Altenburg \& Wymenga, ecological research, Veenwouden. Wetlands International, Dakar.

Boutin J. \& Cherain Y., 1989 - Compte rendu ornithologique camarguais pour les années 1986 et 1987. Revue d'Écologie-La Terre et la Vie, 44 (2): 165-189.

Bräunlich A., 2002 - Birding in Central Asia: an introduction to Mongolia. Oriental Bird Club Bulletin, 35: 62-70.

Brichetti P. \& Fracasso G., 2007 - Ornitologia Italiana. Vol. IV. Alberto Perdisa Editore.

Bright J. A., Morris A. J. \& Winspear R., 2008 - A review of Indirect Effects of Pesticides on Birds and mitigating land-management practices. RSPB Research Report No 28. The Royal Society for the Protection of Birds, The Lodge, Sandy, Bedfordshire.

Britton P. L. (ed.), 1980 - Birds of East Africa: their habitat, status and distribution. East Africa Natural History Society, Nairobi.
Brooks M., 2017a - Southern African Bird Atlas Project 2: Full protocol records. Version 1.12. Animal Demography Unit, Department of Zoology, University of Cape Town.

Brooks M., 2017b - Coordinated Waterbird Counts. Version 1.80. Animal Demography Unit, Department of Zoology, University of Cape Town.

Brosset A. \& Érard C., 1986 - Les oiseaux des régions forestières du nord-est du Gabon. Vol. 1. Écologie et Comportement des Espèces. Société Nationale de Protection de la Nature, Paris.

Buitenwerf R., Bond W. J., Stevens N. \& Trollope W. S. W., 2012 Increased tree densities in South African savannas: 50 years of data suggests $\mathrm{CO}_{2}$ as a driver. Global Change Biology, 18 (2): 675-684.

Buontempo C., 2010 - Sahelian climate: past, current, projections. Met Office Hadley Centre, Devon, UK. <http://www.oecd.org/swac/ publications/47092928.pdf> (retrieved in December 2017).

Calabuig I., 2013 - Western Palearctic migratory birds in continental Africa. Center for Macroecology, Evolution and Climate, University of Copenhagen. Occurrence Dataset $<$ https://doi.org/10.15468/ qjmrtx $>$ (accessed via GBIF.org on 2017-12-24).

Carruthers V., 2000 - The Wildlife of Southern Africa: A Field Guide to the Animals and Plants of the region. Struik Publishers, Cape Town.

Carswell M., 1986 - Birds of the Kampala Area. Scopus, Special Supplement Number 2.

Chamberlain C. P., Bensch S., Feng X., Åkesson S. \& Anderson T., 2000 - Stable isotopes examined across a migratory divide in Scandinavian Willow Warblers Phylloscopus trochilus trochilus and Phylloscopus trochilus acredula reflect their African winter quarters. Proceedings of the Royal Society of London, B 267: 4348.

Chapin J. P., 1953 - The Birds of the Belgian Congo, part 3. Bulletin of the American Museum of Natural History, 3: 95.

Chernetsov N., Kishkinev D., Gashkov S., Kosarev V. \& Bolshakov C. V., 2008 - Migratory programme of juvenile pied flycatchers, Ficedula hypoleuca, from Siberia implies a detour around Central Asia. Animal Behaviour, 75 (2): 539-545.

Chipanshi A. C., Ripley E. A. \& Lawford R. G., 1999 - Large-scale simulation of wheat yields in a semi-arid environment using a cropgrowth model. Agricultural Systems, 59 (1): 57-66.

Christensen J. H., Hewitson B., Busuioc A., Chen A., Gao X., Held I., Jones R., Kolli R. K., Kwon W.-T., Laprise R., Magana Rueda V., Mearns L., Menendez C. G., Raisanen J., Rinke A., Sarr A. \& Whetton P., 2007 - Regional climate projections. In: Climate Change 2007: the Physical Science Basis. Solomon S., Qin D., Manning M., Chen Z., Marquis M., Averyt K. B., Tignor M. \& Miller H. L. (eds.). Contribution of Working Group I to the Fourth Assessment Report of the Intergovernmental Panel on Climate Change, Cambridge University Press, Cambridge, UK and New York, NY, USA: 847-940.

Clancey P. A., 1966 - A catalogue of birds of the South African Sub-Region (Part IV: Families Sylviidae-Prionopidae). Durban Museum Novitates, 7 (12): 465-543.

Clarke G., 1985 - Bird observations from Northwest Somalia. Scopus, 9: $24-42$.

Cocker M. \& Mikkola H., 2001 - Magic, myth and misunderstanding: cultural responses to owls in Africa and their implications for conservation. Bulletin of the African Bird Club, 8 (1): 30-35.

Coetzer D. \& Ranwashe F., 2015 - SAFRING: Historical Bird Ringing Records (2005-2009). South African National Biodiversity Institute.

Coppack T. \& Both C., 2002 - Predicting life-cycle adaptation of migratory birds to global climate change. Ardea, 90: 369-377.

Coppack T. \& Pulido F., 2004 - Photoperiodic response and the adaptability ofavian lifecycles to climate change. Advances in Ecological Research, 35: 131-150.

Cordeiro N. J., 1994 - Forest birds on Mt Kilimanjaro, Tanzania. Scopus, 17: 65-112.

Cova C., 1969 - Atlante degli uccelli d'Italia. Hoepli, Milano.

Cramp S. (ed.), 1988 - The Birds of the Western Palearctic. Vol. V: Tyrant Flycatchers to Thrushes. Oxford University Press, Oxford. 
Curry P. J. \& Sayer J. A., 1979 - The Inundation Zone of the Niger as an environment for Palaearctic migrants. The Ibis, 121 (1): 20-40.

Curry-Lindahl K., 1963 - Molt, body weights, gonadal development and migration in Motacilla flava. XIIIth International Ornithological Congress, Ithaca: 960-973.

Curry-Lindahl K., 1964 -Yellow Wagtails Motacilla flava flavissima found in great numbers on Mount Nimba, Liberia. The Ibis, 106: 255-256.

Curry-Lindahl K., 1965 - Physiological aspects of bird migrations based on a transequatorial migrant, the Yellow Wagtail (Motacilla flava). Travaux du Muséum National d'Histoire Naturelle "Grigore Antipa”, 5: 381-388.

Daniels C. L. \& Stevens C. M., 1903 - Encyclopaedia of superstitions, folklore, and the occult sciences of the world; a comprehensive library of human belief and practice in the mysteries of life. Vol. II. University Press of the Pacific, Honolulu, Hawaii.

David R., 2002 - Religion and Magic in Ancient Egypt. Penguin Books Ltd, London.

de Juana E. \& Garcia E., 2015 - The Birds of the Iberian Peninsula. Christopher Helm, London.

del Hoyo J., Elliott A. \& Christie D. A., 2004 - Handbook of the Birds of the World. Volume 9. Cotingas to Pipits and Wagtails. Lynx Edicions, Barcelona.

Dementiev G. P. \& Gladkov N. A. (eds.), 1954 - Ptitsy Sovyet Soyuza. [The birds of the Soviet Union]. Vol. 5. Sovetskaya Nauka, Moskva.

Dowsett R. J., 1965 - The occurrence of the Yellow Wagtail Motacilla flava flavissima in Central Africa. Ostrich, 36 (1): 32-33.

Dowsett R. J., 1969 - Migrants at Malam'Fatori, Lake Chad, Autumn 1968. Bulletin of the Nigerian Ornithologists'Society, 6: 39-45.

Ebbutt D., Horwood M. T., Sharland R. E. \& Smith V. W., 1964 - Provisional check-list of the birds of Plateau Province over 3,000 feet. Bulletin of the Nigerian Ornithologists 'Society, 1 (3): 9-14.

EEA (European Environment Agency), 2009 - Observed temperature change over Europe 1976-2006. European Environment Agency, Luxembourg. <https://www.eea.europa.eu/data-and-maps/figures/ observed-temperature-change-over-europe-1976-2006> (retrieved in December 2017).

EEA (European Environment Agency), 2017 - Climate change, impacts and vulnerability in Europe 2016. EEA Report No 1/2017. European Environment Agency, Luxembourg.

Eriksen J. \& Porter R., 2017 - Birds of Oman. Helm Field Guides. Christopher Helm, London.

Eyhorn F., Roner T. \& Specking H., 2015 - Reducing pesticide use and risks. What action is needed? Helvetas, Swiss Intercooperation.

FAO, 2016 - AQUASTAT website. Food and Agriculture Organization of the United Nations (FAO) <http://www.fao.org/nr/water/aquastat/main/index.stm $>$ (retrieved in December 2017).

Ferlini F., 1994 - Osservazioni ornitologiche nell'Isola di Kos (Grecia). Uccelli'Italia, 19 (1-2): 77-80.

Ferlini F., 2015 - Evolution of the breeding range of the "italian" Wagtail Motacilla flava cinereocapilla. Rivista Italiana di Ornitologia, 85 (2): 3-18

Ferlini F., 2016 - Evolution of the breeding range of the Black-headed Yellow Wagtail (Motacilla flava feldegg). Rivista Italiana di Ornitologia, 86 (1): 3-38.

Finlayson C., 1992 - Birds of the Strait of Gibraltar. T. \& A. D. Poyser, London.

Fintha I., 1988 - Observations of Palaearctic migrants in Tanzánia (1979-1982). Aquila, 95: 11-57.

Forget G., 2010 - Oiseaux du Senegal. Un recueil de photographies. Vol. 2. Editore, Quebec.

Fotso R. C., 2001 - A contribution to the ornithology of Mount Oku forest, Cameroon. Malimbus, 23: 1-12.

Fry C. H., 1965a - Bird notes from North-Eastern Sokoto Province. Bulletin of the Nigerian Ornithologists'Society, 1 (4): 2-5.

Fry C. H., 1965b - The birds of Zaria. II. Palaearctic migrants. Bulletin of the Nigerian Ornithologists'Society, 2: 35-44.

Fry C. H., Ferguson-Lees I. J. \& Dowsett R. J., 1972 - Flight muscle hypertrophy and ecophysiological variation of Yellow Wagtail Motacilla flava races at Lake Chad. Journal of Zoology, 167 (3): 293-306.
Funk C., Michaelsen J. \& Marshall M., 2012 - Mapping recent decadal climate variations in precipitation and temperature across Eastern Africa and the Sahel. In: Remote Sensing of Drought: Innovative Monitoring Approaches. Wardlow B. D., Anderson M. C. \& Verdin J. P. (eds.). CRC Press, Boca Raton, FL, USA: 331-358.

Gall L., 2017 - Vertebrate Zoology Division. Ornithology, Yale Peabody Museum. Yale University Peabody Museum. Occurrence Dataset $<$ https://doi.org/10.15468/h25uz7 $>$ (Accessed via GBIF.org on 2017-12-11. Peabody Museum. Vertebrate Zoology Division - Ornithology, Yale Peabody Museum).

Gargallo G., Barriocanal C., Castany J., Clarabuch O., Escandell R., López-Iborra G., Rguibi-Idrissi H., Robson D. \& Suárez M., 2011 Mediterranean and NW Africa: the results of 16 years of the Piccole Isole project. Monografies del Museu de Ciències Naturals 6, Museu de Ciències Naturals, Institut de Cultura, Ajuntament de Barcelona.

Gatter W., 1987 - Bird migration in West Africa: Observations and hypotheses on migration strategies and migration routes. Bird migration in Liberia, Part II. Die Vogelwarte, 34: 80-92.

Gavrilov E. I. \& Gavrilov A. E., 2005 - The Birds of Kazakhstan. Almaty.

Gill F. \& Donsker D. (eds.), 2017 - IOC World Bird List (v 7.3). <Doi 10.14344/IOC.ML.7.3>. <http://www.worldbirdnames.org/> (retrieved in December 2017).

Gillon Y. \& Gillon D., 1974 - Recherches écologiques sur une savane sahélienne du Ferlo septentrional, Shegal. Données quantitatives sur les Ténébrionides. Revue d'Écologie-La Terre et la Vie, 28: 296-306.

Goldewijk K. K., 2001 - Estimating global land use change over the past 300 years: The HYDE Database. Global Biogeochemical Cycles, 15 (2): 417-433.

Golovatin M. G. \& Sokolov V. A., 2017 - Distribution of Yellow Wagtail Forms Motacilla flava. Complex in the North of Western Siberia, Russia. The Open Ornithology Journal, 10: 1-9.

Goodman S. M. \& Atta G. A. M., 1987 - The birds of Southeastern Egypt. Gerfaut, 77: 3-41.

Goulson D., 2014 - Ecology: Pesticides linked to bird declines. Nature, 511: 295-296

Grant C. H. B. \& Mackworth-Praed C. W., 1942 - Notes on Eastern African Birds. Bulletin of the British Ornithologists' Club, 62: 5859.

Grant C. H. B. \& Mackworth-Praed C. W., 1952 - On the species and races of the Yellow Wagtails from Western Europe to Western North America. Bulletin of the British Museum (Natural History) Zoology, 1 (9): 253-270.

Grant S. \& Marks B., 2017 - Field Museum of Natural History (Zoology) Bird Collection. Version 14.3. Field Museum. Occurrence Dataset <https://doi.org/10.15468/exkxdx> (Accessed via GBIF. org on 2017-08-03).

Green A. A., 1984 - Additional bird records from Bamingui-Bangoran National Park, Central African Republic. Malimbus, 6: 70-72.

Greene A. M., Giannini A. \& Zebiak S.E., 2009 - Drought return times in the Sahel: a question of attribution. Geophysical Research Letters, 36 (12), L12701. <doi:10.1029/2009GL038868>

Grieve A., 2000 - Egypt Trip Report Cairo, Nile Delta and Sinai 1 to 13 December 1999. <http://www.osme.org/trip-reports/egtrip6> (retrieved in December 2017).

Grimes L. G., 1971 - Notes on some birds seen at Buea and on Mount Cameroon, 30 Dec. 1970 - Jan. 1971. Bulletin of the Nigerian Ornithologists'Society, 8: 35-41.

Haagner A., 1912 - Sketches of South African Bird-Life. T. M. Miller, Cape Town.

Haagner A. K. \& Ivy R.H., 1923 - Sketches of South African bird-life. T.M. Miller, Cape Town.

Hafner H., Johnson A. \& Walmsley J., 1980 - Compte rendu ornithologique camarguais pour les années 1978 et 1979. Revue d'ÉcologieLa Terre et la Vie, 34 (4): 621-647.

Hagemeijer W. J. M. \& Blair M. J. (eds.), 1997 - The EBCC Atlas of European Breeding Birds: Their distribution and abundance. $T \& A$ Poyser, London. 
Hall P., 1976 - The Birds of the Mambilla Plateau. Bulletin of the Nigerian Ornithologists'Society, 12: 67-72.

Hall P., 1977 - The Birds of Serti. Bulletin of the Nigerian Ornithologists'Society, 13: 66-79.

Hallmann C. A., Foppen R. P. B., van Turnhout C. A. M., de Kroon H. \& Jongejans E., 2014 - Declines in insectivorous birds are associated with high neonicotinoid concentrations. Nature, 511: 341-343.

Hansen K., 2017 - The Rise and Fall of Africa's Great Lake. Scientists Try to Understand the Fluctuations of Lake Chad. NASA Earth Observatory. <https://www.earthobservatory.nasa.gov/ Features/LakeChad/?src=features-recent $>$ (retrieved in December 2017).

Harrison D. L., Allan D. G., Underhill L. G., Herremans M., Tree A. J., Parker V. \& Brown C. J., 1997 - The Atlas of Southern African Birds. Volume II: Passerines. BirdLife South Africa, Johannesburg.

Harrison K., 2006 - Carbofuran. <http://www.3dchem.com/Carbofuran.asp\#> (retrieved in December 2017).

Hartert E., 1886 - Ornithologisehe Ergebnisse einer Reise in den NigerBenuë-Gabiete. Journal für Ornithologie, 34: 570-613.

Hartert E., 1928 - A rush through Tunisia, Algeria, and Marocco, and collecting in the Maroccan Atlas, in 1927. Novitates Zoologicae, 34: 337-371.

Hayhow D. B., Conway G., Eaton M. A., Grice P. V., Hall C., Holt C. A., Kuepfer A., Noble D. G., Oppel S., Risely K., Stringer C., Stroud D. A., Wilkinson N. \& Wotton S., 2014 - The state of the UK's birds 2014. RSPB, BTO, WWT, JNCC, NE, NIEA, NRW and $S N H$, Sandy, Bedfordshire.

Heiss M. \& Eidam F., 2015 - First record of White-headed Yellow Wagtail Motacilla flava leucocephala for Azerbaijan. Sandgrouse, 37 (2): 199-202.

Hellenic Rarities Committee, 2010 - Annual Report - 2009. Hellenic Rarities Committee. <http://rarities.ornithologiki.gr/gr/eaop/annual_reports.htm> (retrieved in December 2017).

Herroelen P., 2006 - Further annotations and an addition to the avifauna of the Democratic Republic of Congo. Bulletin of The British Ornithologists' Club, 126: 19-37.

Higgins S. I. \& Scheiter S., 2012 - Atmospheric $\mathrm{CO}_{2}$ forces abrupt vegetation shifts locally, but not globally. Nature, 488: 209-212. <DOI: 10.1038 /nature11238>

Hockey P. A. R., Dean W. R. J. \& Ryan P. G., 2005 - Robert's Birds of Southern Africa. VII ${ }^{\text {th }}$ ed. The Trustees of the John Voelcker Bird Book Fund, Cape Town.

Hogg P., Dare J. \& Rintoul J. V., 1984 - Palaearctic migrants in the central Sudan. The Ibis, 126 (3): 307-331.

Hopson A. J., 1965 - Preliminary notes on the birds of Malamfatori, Lake Chad. Bulletin of the Nigerian Ornithologists' Society, 1 (4): 7-15.

Iran Bird Records Committee, 2017 - Record of Motacilla flava leucocephala in Aq-Qala. <http://iranbirdrecords.ir/1396/02/18/Motacilla\%20flava\%20leucocephala\%20in\%20Aq-Qala>

IRDC (Israeli Rarities Distribution Committee), 2015 - Bulletin 9:01 Rare Birds in Israel. The Israeli Rarities \& Distribution Committee (IRDC). <http://www.israbirding.com/irdc/bulletins/bulletin_9/> (retrieved in December 2017).

James R. \& Washington R., 2013 - Changes in African temperature and precipitation associated with degrees of global warming. Climatic Change, 117 (4): 859-872.

Jardine W., 1848-1852 - Contributions to Ornithology. W.H. Lizars, Edinburgh.

Kayser Y., Gauthier-Clerc M., Béchet A., Poulin B., Massez G., Chérain Y., Paoli J., Sadoul N., Vialet E., Paulus G., Vincent-Martin N., Pilard P. \& Isenmann P., 2008 - Compte rendu ornithologique camarguais pour les années 2001-2006. Revue d'Écologie-La Terre et la Vie, 63 (4): 299-349.

Keith S., Urban E. K. \& Fry H. (eds.), 1992 - The Birds of Africa, Volume IV: Broadbills to Chats. Academic Press, London, UK.

Kirwan G. M., Özen M., Ertuhan M. \& Atahan A., 2014 - Turkey Bird Report 2007-2011. Sandgrouse, 36: 146-175.

Kishchinski A. A., 1980 - Ptitsi Koryakskogo Nagorya. Izdatel stvo Nauka, Moscow.
Koen J. H., 1988 - Birds of the Eastern Caprivi. Southern Birds, 15, Benmore.

Kovats R. S., Valentini R., Bouwer L. M., Georgopoulou E., Jacob D., Martin E., Rounsevell M. \& Soussana J.-F., 2014 - Europe. In: Climate Change 2014: Impacts, Adaptation, and Vulnerability. Part B: Regional Aspects. Contribution of Working Group II to the Fifth Assessment Report of the Intergovernmental Panel on Climate Change. Barros V. R., Field C. B., Dokken D. J., Mastrandrea M. D., Mach K. J., Bilir T. E., Chatterjee M., Ebi K. L., Estrada Y. O., Genova R. C., Girma B., Kissel E. S., Levy A. N., MacCracken S., Mastrandrea P. R. \& White L. L. (eds.). University Press, Cambridge, United Kingdom and New York, NY, USA: 1267-1326.

Lamarche B., 1981 - Liste commentée des oiseaux du Mali. 2ème partie: Passereaux. Malimbus, 3: 73-102.

Lauer W. \& Frankenberg P., 1988 - Klimaklassifikation der Erde. Geograpische Rundschau, 40. Westermann Verlag, Braunschweig.

Le Vaillant F., 1799 - Histoire naturelle des Oiseaux d'Afrique. Vol III. Chez J.J. Fuchs, Paris.

Leshem Y., Yom-Tov Y., Thompson H., Bennun L. \& Labinger Z., 2006 - The importance of the Great Rift Valley for palearctic bird migration. Abstracts to XXIV International Ornithological Congress, Hamburg. Journal of Ornithology, 147 (1): Supplement 284.

Levatich T. \& Padilla F., 2016 - EOD - eBird Observation Dataset. Cornell Lab of Ornithology. Occurrence Dataset <https://doi. org/10.15468/aomfnb $>$ (Accessed via GBIF.org on 2017-12-11).

Lewis A. \& Pomeroy D., 1989 - A Bird Atlas of Kenya. A.A. Balkema, Rotterdam.

Louette M. \& Prévost J., 1987 - Passereaux collectés par J. Prévost au Cameroun. Malimbus, 9: 83-96.

Lundwall U. \& Persson C., 2006 - Weights, fat levels and distances flown by migrating Scandinavian Yellow Wagtails Motacilla flava in autumn. <http://home4.swipnet.se/ $\sim \mathrm{W}-48087 /$ faglar/materialmapp/arlmapp/ywwmenu.html> (retrieved in December 2017).

Mackworth-Praed C. W. \& Grant C. H. B., 1957 - Birds of Eastern and North Eastern Africa. Longmans, London.

Macleay K. N. G., 1960 - The birds of Khartoum Province. Bulletin No. 1. Natural History Museum, University of Khartoum, Sudan.

Mankwe Wildlife Reserve, 2014 - Checklist for Birds of Mankwe Wildlife Reserve, North West Province, South Africa. <http://www. mankwewildlifereserve.com/uploads/2/6/6/8/26680908/checklist for_birds_of mankwe_wildlife_reserve2014.pdf $>$ (retrieved in December $2 \overline{0} 1 \overline{7}$ ).

Marques D. A. \& Thoma M., 2015 - Seltene Vogelarten und ungewöhnliche Vogelbeobachtungen in der Schweiz im Jahre 2014 - 24. Bericht der Schweizerischen Avifaunistischen Kommission. Der Ornithologische Beobachter, 112 (3): 161-188.

Martinez N. \& Maumary L., 2016 - Seltene Vogelarten und ungewöhnliche Vogelbeobachtungen in der Schweiz im Jahre 2015 - 25. Bericht der Schweizerischen Avifaunistischen Kommission. Der Ornithologische Beobachter: 113 (4): 269-298.

Meinertzhagen R., 1921 - Notes on some Birds from the Near East and from Tropical East Africa. The Ibis, 63 (4): 621-671.

Meinertzhagen R., 1956 - Yellow Wagtails in Kenya. British Birds, 49: 240.

Midgley G. F. \& Thuiller W., 2011 - Potential responses of terrestrial biodiversity in Southern Africa to anthropogenic climate change. Regional Environmental Change, 11 (1): 127-135.

Millen B., 2017 - Ornithology Collection Passeriformes. Royal Ontario Museum. Version 15.8. Occurrence Dataset <https://doi. org/10.15468/ahiyvz $>$ (Accessed via GBIF.org on 2017-08-04).

Mills M. \& Melo M., 2013 - The checklist of the birds of Angola. Associação Angolana para Aves e Natureza (AvesAngola), Luanda, Angola and Birds Angola.

Mineau P., 2005 - Direct Losses of Birds to Pesticides. Beginnings of a Quantification. In: Bird Conservation Implementation and Integration in the Americas: Proceedings of the Third International Partners in Flight Conference. 2002 March 20-24, Asilomar, California. Ralph C. J. \& Rich T. D., (eds.). Dept. of Agriculture, Forest Service, Pacific Southwest Research Station, Volume 2, PSW-GTR-191: 1065-1070. 
Mitchard E. T. A. \& Flintrop C. M., 2013 - Woody encroachment and forest degradation in sub-Saharan Africa's woodlands and savannas 1982-2006. Philosophical Transactions of the Royal Society B, 368; 20120406. <doi:10.1098/rstb.2012.0406>

Mitra A., Chatterjee C. \& Mandal F. B., 2011 - Synthetic Chemical Pesticides and Their Effects on Birds. Research Journal of Environmental Toxicology, 5: 81-96.

Moltoni E., 1970 - Gli uccelli ad oggi riscontrati nelle Isole Linosa, Lampedusa e Lampione (Isole Pelagie, Canale di Sicilia, Mediterraneo). Rivista Italiana di Ornitologia, 40: 77-283.

Moltoni E., 1971 - Gli uccelli ad oggi riscontrati nelle isole di Tavolara, Molara e Molarotto (Sardegna nord-orientale). Rivista Italiana di Ornitologia, 41: 223-372.

Moreau R. E., 1961 - Problems of Mediterranean-Saharan migration. The Ibis, 103 (4): 580-623.

Moreau R. E., 1972 - The Palearctic-African Migration Systems. Academic Press, London.

Morel G. J., 1973 - The Sahel zone as an environment for Palaearctic migrants. The Ibis, 115 (3): 413-417.

Morganti M. \& Pulido F., 2012 - Invernada de aves migradoras transSaharianas en España. In: SEO/BirdLife: Atlas de las aves en invierno en España 2007-2010. Ministerio de Agricultura, Alimentacion y Medio Ambiente-SEO/BirdLife, Madrid: 59-64.

Morganti M., Gordo O. \& Pulido F., 2014 - Rapid shortening of migratory distances of recently establisched wintering populations of trans-Saharan birds in the Western Mediterranean. In: PhD Thesis. The potential of migratory birds to adapt to global change: lessons from European long-distance migrants and Iberian Blackcaps. Morganti M. Universidad Complutense Madrid: 95-105.

Mullié W. C., Verwey E. J., Berends A. G., Séne F., Koeman J. H. \& Everts J. W., 1991 - The Impact of Furadan 3G (Carbofuran) Applications on Aquatic Macroinvertebrates in Irrigated Rice in Senegal. Archives of Environmental Contamination and Toxicology, 20: $177-182$.

Mullié W. C. \& Diop M.S., 2001 - The impact of pesticide use in Africa on Palearctic-African migrant waterbirds: A call for quantitative data for a new UNEP-AEWA study. In: Wings over Africa. Leshem Y., Froneman A., Mundy P. \& Shamir H. (eds.). Proceeding of International Seminar on Bird Migration, Israel, April 29-May 11, 2001: 94-101.

Mundy P., 2000 - Wetland birds of the Zambezi Basin. In: Biodiversity of the Zambezi Basin wetlands. Timberlake J. (ed.). Biodiversity Foundation for Africa, Bulawayo/The Zambezi Society, Harare, Zimbabwe: 213-278.

Museums Victoria, 2017 - Museums Victoria provider for OZCAM. Occurrence dataset <https://doi.org/10.15468/lp1ctu> (Accessed via GBIF.org 2017-07-08).

Naturgucker, 2016 - Naturgucker.de. Occurrence Dataset <https://doi. org/10.15468/uc1 apo> (Accessed via GBIF.org on 2017-07-08).

Neave S. A., 1910 - On the Birds of Northern Rhodesia and the Katanga District of Congoland. Part II. The Ibis, 4 (ser. 9): 225-262.

Newman K., 2002 - Newman's Birds of Southern Africa. Struik Publishers, Cape Town.

Newman K., 2003 - What's That Bird? A Starter's Guide to Birds of Southern Africa. Struik Publishers, Cape Town.

Newton I., 1998 - Population Limitation in Birds. Academic Press, London.

Newton I., 2008 - The migration ecology of Birds. Academic Press, London.

Newton I., 2011 - Migration within the annual cycle: species, sex and age differences. Journal für Ornithologie, 152 (S1): 169-185.

Niang I., Ruppel O. C., Abdrabo M. A., Essel A., Lennard C., Padgham J. \& Urquhart P., 2014 - Africa. In: Climate Change 2014: Impacts, Adaptation, and Vulnerability. Part B: Regional Aspects. Barros V. R., Field C. B., Dokken D. J., Mastrandrea M. D., Mach K. J., Bilir T. E., Chatterjee M., Ebi K. L., Estrada Y. O., Genova R. C., Girma B., Kissel E. S., Levy A. N., MacCracken S., Mastrandrea P. R. \& White L. L. (eds.). Contribution of Working Group II to the Fifth Assessment Report of the Intergovernmental Panel on Climate Change. Cambridge University Press, Cambridge, United Kingdom and New York, NY, USA: 1199-1265.
Nicholson S. E., 1994 - Recent rainfall fluctuations in Africa and their relationships to past conditions over the continent. The Holocene, 4: 121-131.

Nicholson S.E., 1998a - Historical fluctuations of Lake Victoria and other lakes in the Northern Rift Valley of East Africa. In: Environmental change and response in East African lakes. Lehman J. T. (ed.). Kluwer, Dordrecht: 7-35.

Nicholson S. E., 1998b - Fluctuations of Rift Valley Lakes Malawi and Chilwa during historical times: a synthesis of geological, archaeological and historical information. In: Environmental change and response in East African lakes. Lehman J. T. (ed.). Kluwer, Dordrecht: 207-231.

Nicholson S. E., 1999 - Historical and modern fluctuations of Lakes Tanganyika and Rukwa and their relationship to rainfall variability. Climatic Change, 41: 53-71.

Nicholson S. E., 2001 - Climatic and environmental change in Africa during the last two centuries. Climate Research, 17: 123-144.

Nicholson S. E., Nash D. J., Chase B. M., Grab S. W., Shanahan T. M., Verschuren D., Asrat A., Lezine A.-M. \& Umer M., 2013 - Temperature variability over Africa during the last 2000 years. Holocene, 23 (8): 1085-1094.

Nikolaus G., 1989 - Birds of South Sudan. Scopus, special supplements N. 3.

Nikolaus G., 2001 - Bird exploitation for traditional medicine in Nigeria. Malimbus, 23: 45-55.

Nikolaus G., 2011 - The fetish culture in West Africa: An ancient tradition as a threat to endangered birdlife? In: Tropical vertebrates in a changing World. Schuchmann K.-L. (ed.). Zoologisches Forschungsmuseum Alexander Koenig, Bonn: 145-150.

Https://observation.org/, 2017 - Motacilla flava. <https://observation. org/> (retrieved in December 2017).

Ödeen A., 2001 - Effects of Post-Glacial Range Expansions and Population Bottlenecks on Species Richness. Acta Universitatis Upsaliensis, Comprehensive Summaries of Uppsala Dissertations from the Faculty of Science and Technology, Uppsala.

Odino M., 2011 - Measuring the conservation threat to birds in Kenya from deliberate pesticide poisoning: a case study of suspected carbofuran poisoning using Furadan in Bunyala Rice Irrigation Scheme. In: Carbofuran and Wildlife Poisoning: Global Perspectives and Forensic Approaches. Richards N. L. (ed.). Wiley, UK: 53-70.

Odino M. \& Ogada D. L., 2008 - Furadan use in Kenya and its impacts on birds and other wildlife: a survey of the regulatory agency, distributors, and end-users of this highly toxic pesticide. Report to the Bird Committee of Nature Kenya.

Ogada D. L., 2014 - The power of poison: pesticide poisoning of Africa's Wildlife. Annals of the New York Academy of Sciences, 1322: $1-20$.

Orrell T. \& Hollowell T., 2017 - NMNH Extant Specimen Records. Version 1.8. National Museum of Natural History, Smithsonian Institution. Occurrence Dataset <https://doi.org/10.15468/hnhrg3> (Accessed via GBIF.org on 2017-07-14).

Oschadleus D. \& Ranwashe F., 2017 - SAFRING: Historical Bird Ringing Records (2005-2009). Version 1.1. South African National Biodiversity Institute. (Retrieved in March 2018).

Oustalet M. E., 1904-1905 - Catalogue des oiseaux rapportés par la mission Chari-lac Tchad. Bulletin du Muséum d'Istoire Naturelle, Impr. Nationale, Paris.

Ouwehand J., Ahola M. P., Ausems A. N. M. A., Bridge E. S., Burgess M., Hahn S., Hewson C. M., Klaassen R. H. G., Laaksonen T., Lampe H. M., Velmala W. \& Both C., 2016 - Light-level geolocators reveal migratory connectivity in European populations of pied flycatchers Ficedula hypoleuca. Journal of Avian Biology, 47 (1): 69-83.

Parker V., 1999 - The atlas of the birds of Sul do Save, Southern Mozambique. Avian Demography Unit, Cape Town, and the Endangered Wildlife Trust, Johannesburg.

Parsons K. C., Mineau P. \& Renfrew R. B., 2010 - Effects of Pesticide use in Rice Fields on Birds. Waterbirds, 33 (1): 193-218.

Pearson D. J., 1972 - The wintering and migration of palaearctic passerines at Kampala, Southern Uganda. The Ibis, 114 (1): 43-60.

Pearson D. J., 1983 - East African Bird Report 1982. Scopus, 6: 109128. 
Pearson D. J. \& Backhurst G. C., 1973 - The head plumage of Eastern Yellow-Headed Yellow Wagtails Wintering at Nairobi, Kenya. The Ibis, 115 (4): 589-591.

Pearson D. J. \& Britton P. L., 1980 - Arrival and departure times of Palaearctic waders on the Kenyan coast. Scopus, 4: 84-88.

Pearson D. J. \& Turner D. A., 1986 - The less common Palearctic Migrant Birds of Uganda. Scopus, 10 (3/4): 61-82.

Pedersen T., 2009 - Democratic Republic of Congo. A bird checklist. Manca editore o sito.

Pennycuick C. J., 1975 - Mechanics of flight. In: Avian Biology. Vol. V. Farmer D. S. \& King J. R. (eds.). Academic Press, New York and London: 1-75.

Pérez-Tris J. \& Asensio B., 1997 - Migracion e invernada de la Lavandera boyera (Motacilla flava) en la Peninsula Iberica. Ardeola, 44 (1): 71-78.

Pinch G., 2002 - Egyptian Mythology: A Guide to the Gods, Goddesses, and Traditions of Ancient Egypt. Oxford University Press.

Porter R. \& Aspinall S., 2010 - Birds of the Middle East. Christopher Helm, London.

Prescott G., 2012 - Egypt, Luxor - 3-10 December 2012. <http://www. surfbirds.com/trip_report.php?id $=2277>$ (Retrieved in December 2017).

Quirke S., 2001 - The Cult of Ra: Sun Worship in Ancient Egypt. Thames \& Hudson Ltd, London.

RAF Ornithological Society, 2016 - The Cyprus Expeditions. <http:// www.rafornithology.org.uk/wp-content/uploads/2016/12/Cyprusvisits-overview.pdf> (Retrieved in December 2017).

Rappolle J. H, 2013 - The Avian Migrant: The Biology of Bird Migration. Columbia University Press, New York.

Redford D. B., 2002 - The Ancient Gods Speak: A Guide to Egyptian Religion. Oxford University Press.

Redkin Ya.A., 2011 - Новые данные о пространственных и репродуктивных отношениях некоторых близкородственных форм воробьинообразных Passeriformes в Туве. Русский орнитологический журнал, 2011, 20 (652): 839-853.

Redkin Ya.A., 2013 - Желтолобая трясогузка. In: Полный определитель птиц европейской части России, Kalyakina M. V. (eds.). Vol. 3: 60-63.

Redman N., Stevenson T. \& Fanshawe J., 2009 - Birds of the Horn of Africa: Ethiopia, Eritrea, Djibouti, Somalia and Socotra. Christopher Helm.

Réserve Nationale de Camargue, 1987 - Compte rendu ornithologique camarguais pour les années 2001-2006. Revue d'Écologie-La Terre et la Vie, 42 (2): 167-191.

http://Ricepedia.org, 2017 - Madagascar. <http://ricepedia.org/madagascar>

Riethmuller M., 2017 - Bergeronnette printanière (Motacilla flava). $<$ http://www.faune-reunion.fr/index.php?m_id=54\&mid=6570> (Retrieved in December 2017).

Roberts A., 1911 - Notes on a few Birds from Wakkerstroom. The Journal of the South African Ornithologists'Union, 7: 21-23.

Ruelle P. J., 1983 - Control of granivorous bird pests of rice using the partial crop treatment method in West Africa. International Journal of Tropical Pest Management, 29 (1): 23-26.

Rüppell E., 1845 - Systematische Uebersicht der Vögel Nord-OstAfrika's: nebst Abbildung und Beschreibung von fünfzig Theils unbekannten, Theils noch nicht bildlich dargestellten Arten. Commission der S. Schmerber'schen Buchhandlung, Frankfurt A.M.

Sala O. E., Chapin F. S., \& Amesto J. J., 2000 - Global biodiversity scenarios for the year 2100. Science, 287: 1770-1774.

Salvan J., 1967 - Contribution à l'etude des oiseaux du Tchad. Oiseau et R.F.O., 37: 255-284.

Salvan J., 1969a - Contribution à l'etude des oiseaux du Tchad. Oiseau et R.F.O., 38: 53-85.

Salvan J., 1969b - Contribution à l'etude des oiseaux du Tchad. Oiseau et R.F.O., 38: 127-150.

Salvan J., 1969c - Contribution à l'etude des oiseaux du Tchad. Oiseau et R.F.O., 38: 255-284.

Schewe J. \& Levermann A., 2017 - Non-linear intensification of Sahel rainfall as a possible dynamic response to future warming. Earth System Dynamics, 8: 495-505.
Schouteden H., 1963 - La faune omithologique des districts du BasUele et du Haut-Uele. Zoologique Museum Royal de l'Afrique Centrale, 4: 1-241.

Sharland R. E., 1964 - Bird ringing in Nigeria and Ghana, 1963. Sixth annual report. Bulletin of the Nigerian Ornithologists' Society, 1 (1): $11-13$.

Sharland R. E., 1965 - Bird ringing in Nigeria, 1964. Seventh annual report. Bulletin of the Nigerian Ornithologists 'Society, 2: 2-5.

Sharland R. E., 1966 - Ringing in Nigeria, 1965. Eighth annual report. Bulletin of the Nigerian Ornithologists'Society, 3: 18-21.

Sharland R. E., 1967a - Bird ringing in Nigeria 1966. Ninth annual report. Bulletin of the Nigerian Ornithologists'Society, 4 (1): 12-16.

Sharland R. E., 1967b - Recoveries of flava wagtails. Bulletin of the Nigerian Ornithologists'Society, 4 (2): 12.

Sharland R. E., 1968 - Bird ringing in Nigeria 1967. Tenth annual report. Bulletin of the Nigerian Ornithologists'Society, 5: 28-31.

Sharland R. E., 1969 - Ringing in Nigeria, 1968: Eleventh annual report. Bulletin of the Nigerian Ornithologists 'Society, 6: 26-29.

Sharland R. E., 1972a - Ringing in Nigeria 1970: $13^{\text {th }}$ Annual Report. Bulletin of the Nigerian Ornithologists 'Society, 9: 1-6.

Sharland R. E., 1972b - Ringing in Nigeria 1971: $14^{\text {th }}$ Annual Report. Bulletin of the Nigerian Ornithologists' Society, 9: 13-16.

Sharland R. E., 1974 - Ringing in Nigeria $1972 \& 1973: 15^{\text {th }}$ and $16^{\text {th }}$ Annual Reports. Bulletin of the Nigerian Ornithologists' Society, 10: $69-73$

Sharland R. E., 1975 - Ringing in Nigeria 1974. 17 $7^{\text {th }}$ Annual Report. Bulletin of the Nigerian Ornithologists 'Society, 11: 50-52.

Sharland R. E., 1978 - Ringing in Nigeria 1977. $20^{\text {th }}$ Annual Report. Bulletin of the Nigerian Ornithologists 'Society, 14: 24-26.

Sharland R. E., 1979 - Ringing in Nigeria 1978. $21^{\text {st }}$ Annual Report. Malimbus, 1: 43-46.

Sharland R. E., 1985 - Ringing in Nigeria in 1984. Malimbus, 7: 140.

Sharland R.E., 1996 - Ringing recoveries between Nigeria and Eastern Europe. Malimbus, 18: 103.

Sharpe R. B., 1871 - Catalogue of African Birds in the collection of R.B. Sharpe. Sharpe R.B, published by the Author, London.

Sheahan M. \& Barrett C. B., 2014 - Understanding the Agricultural Input Landscape in Sub-Saharan Africa. Recent Plot, Household, and Community-Level Evidence. Policy Research Working Paper No. 7014. World Bank Group, Washington, DC.

Sheahan M. \& Barrett C. B., 2017 - Ten striking facts about agricultural input use in Sub-Saharan Africa. Food Policy, 67: 12-25.

Shelley G. E., 1900 - The birds of Africa, comprising all the species which occur in the Ethiopian region. Vol. II. R.H. Porter, London.

Siebert S. \& Frenken K., 2014-Irrigated Areas. In: Atlas of African Agriculture Research \& Development. Sebastian K. (ed.). International Food Policy Research Institute (IFPRI), Washington, D.C.: 18-19.<http://dx.doi. org/10.2499/9780896298460_08> (Retrieved from http://agatlas.org).

Sinclair I., 1994 - Field Guide to the Birds of Southern Africa. Struik Publishers, Cape Town.

Sinclair I. \& Davidson I., 2006 - Sasol Southern African Birds: A Photographic Guide. Struik Publishers, Cape Town.

Sinclair I., Hockey P. \& Tarboton W., 2002 - Sasol Voëls van SuiderAfrika, Sasol.

Sinclair I., Hockey P. A. R., Arlott N. \& Hayman P., 2005 - The Larger Illustrated Guide to Birds of Southern Africa. Struik Publishers, Cape Town.

Smith D., 2014 - Tunisia Naturetrek Tour Report 15-23 March 2014. <https://www.naturetrek.co.uk/reports_new/TUN01_report_140315_ Tunisia.pdf $>$ (retrieved in December 2017).

Smith S., 1950 - The Yellow Wagtail. Collins, London.

Smithers R. H. N., 1964 - A check list of the birds of the Bechuanaland Protectorate and the Caprivi Strip. Trustees of the National Museum of S. Rhodesia.

SOVON, 2002 - Atlas van de Nederlandse broedvogels 1998-2000. Nederlandse Fauna, 5: 1-584.

SOVON, 2017 - Vogels in Nederland. Engelse Kwikstaart. <https:// www.sovon.nl/nl/soort/10172> (Retrieved in December 2017).

Stern D. I., Gething P. W., Kabaria C. W., Temperley W. H., Noor A. M., Okiro E. A., Shanks G. D., Snow R. W. \& Shay I., 2011 - Temperature and malaria trends in highland East Africa. PLoS ONE, 6 (9), e24524. < doi:10.1371/journal.pone.0024524> 
Stevenson T. \& Fanshawe J., 2002 - Birds of East Africa: Kenya, Tanzania, Uganda, Rwanda, Burundi. T. \& A.D. Poyser, London.

Tarboton W. R., Kemp M. I. \& Kemp A. C., 1987 - Birds of the Transvaal. Transvaal Museum, Pretoria.

Telenius A. \& Ekström J., 2017 - Lund Museum of Zoology (MZLU). GBIF-Sweden.

Tellería J. L., 1988 - Caracteres generales de la memada de las aves en la Peninsula Iberica. In: Invernada de aves en la Peninsula Iberica. Tellería J. L. (ed.). Monografias de la Sociedad Española de Ornitologia, Madrid, 1: 13-22.

Tellería J. L., Asensio B. \& Díaz M., 1999 - Aves Ibéricas, vol II. Paseriformes. J.M. Reyero Editor, Madrid.

Tissier D., 2015 - La Bergeronnette printanière dans le département du Rhône et Lyon Métropole. LPO Rhône. L'Effraie, 40: 4-26.

Torben W., 1950 - Birds collected by the Atlantide-Expedition to West Africa 1945-46. Atlantide Report, 1: 131-149.

Trémolières M., 2010 - Security and environmental variables: The debate and an analysis of links in the Sahel. OECD's Sahel and West Africa Club Secretariat.

Trombone T., 2013 - AMNH Bird Collection. American Museum of Natural History. Occurrence Dataset $<$ https://doi.org/10.15468/ xvzdcm $>$ (Accessed via GBIF.org on 2017-08-03).

Tushabe H., 2015 - National Biodiversity Data Bank. Observation records, 1900-2014. Albertine Rift Conservation Society (ARCOS). Occurrence Dataset <https://doi.org/10.15468/djzgie> (Accessed via GBIF.org on 2017-12-24).

Tyler S. \& Christie D. A., 2017 - western yellow wagtail (Motacilla flava). In: Handbook of the Birds of the World Alive. del Hoyo J., Elliott A., Sargatal J., Christie D. A. \& de Juana E. (eds.). Lynx Edicions, Barcelona. (Retrieved in December 2017).

van Oosten H. H. \& Emtsev A. A., 2013 - Putative segregation of two Yellow Wagtail taxa by breeding habitat in Western Siberia: possible implications for Motacilla flava taxonomy. Ardea, 101: 65-70.

van Someren V. G. L., 1931 - Catalogue of the European and Asiatic migrants to Kenya and Uganda, with brief outline of the subject of migration of birds. The Journal of the East Africa and Uganda Natural History Society. Special Supplement 4.

Wallace D. I. M., 1955 - The mixing of the races of the Yellow Wagtail in Kenya. British Birds, 48 (8): 337-340.

Walther B. A., van Niekerk A., Thuiller W., Baumann S., Dean W. R. J., de Bruijn B., Gutteridge K., Jones P. J., Nikolaus G., Pearson D. J., Robinson S. P., Salewski V., Schäffer N., Taylor P. B., Tushabe H., Williams P. H. \& Rahbek C., 2010 - A database of Western Palearctic birds migrating within Africa to guide conservation decisions. In: Proceedings of the $12^{\text {th }}$ Pan-African Ornithological Congress, 2008. Harebottle D. M., Craig A. J. F. K., Anderson M. D., Rakotomanana H. \& Muchai M. (eds.). Cape Town, Animal Demography Unit: 50-104.

Ward D., 2005 - Do we understand the causes of bush encroachment in African savannas? African Journal of Range \& Forage Science, 22: 101-105.

Ward M. \& Ward Z., 2004 - Gambia 26/11/04 - 10/12/04. <http://www. birdtours.co.uk/tripreports/gambia/gambia22/gamb-04.htm $>$ (retrieved in December 2017).

Wassink A., 2009 - Birds of Kazakhstan: new and interesting data, part 2. Dutch Birding, 31 (2): 101-110.

Wassink A., 2015 - The new Birds of Kazakhstan. De Cocksdorp. Texel, Nederland.

Wassink A., 2016 - The Birds of Kazakhstan. NEW(S). http://birdsofkazakhstan.com/news/ (Accessed 2017-07-08).

Wassink A. \& Oreel G. J., 2008 - Birds of Kazakhstan: new and interesting data. Dutch Birding, 30: 93-100.

Wells D. \& Walsh F., 1969 - Birds of Northern and Central Borgu - Part 3. Bulletin of the Nigerian Ornithologists' Society, 6: 78-93.

Wernham C. V., Toms M. P., Marchant J. H., Clark J. A., Siriwardena G. M. \& Baillie S. R. (eds.), 2002 - The Migration Atlas: movements of the birds of Britain and Ireland. T. \& A.D. Poyser, London.

Westermann, 2010 - Diercke International Atlas. Westermann Schulbuch, Braunschweig.

Wigley B. J., Bond W. J. \& Hoffman M. T., 2009 - Bush encroachment under three contrasting land-use practices in a mesic South African savanna. African Journal of Ecology, 47 (1): 62-70.
Wigley B. J., Bond W. J. \& Hoffman M. T., 2010 - Thicket expansion in a South African savanna under divergent land use: local vs. global drivers? Global Change Biology, 16 (3): 964-976.

Wilkinson R. H., 2003 - The Complete Gods and Goddesses of Ancient Egypt. Thames \& Hudson Ltd, London.

Williams V. L., Cunningham A. B., Bruyns R. K. \& Kemp A. C., 2013 Birds of a Feather: Quantitative Assessments of the Diversity and Levels of Threat to Birds Used in African Traditional Medicine. In: Animals in Traditional Folk Medicine. Alves R. \& Rosa I. (eds.), Springer, Berlin, Heidelberg.

Williams V. L., Cunningham A. B., Kemp A. C. \& Bruyns R. K., 2014 Risks to Birds Traded for African Traditional Medicine: A Quantitative Assessment. PLOS ONE, 9 (8): 1-17.

Williamson K., 1955 - Migrational drift and the Yellow Wagtail complex. British Birds, 48 (9): 383-403.

Wilson A. M. \& Vickery J. A., 2005 - Decline in Yellow Wagtail Motacilla flava flavissima breeding on lowland wet grassland in England and Wales between 1982 and 2002. Bird Study, 52 (1): 88-92.

Winterbottom J. M., 1968 - A check list of the land and fresh water birds of the Western Cape Province. Annals of the South African Museum, 53: 1-276.

Wolanski P., 2012 - Adverse effects of agrochemicals on migratory waterbirds in Africa. Agreement on the conservation of African-Eurasian Migratory Waterbirds - 5th Session of the meeting of the Parties. MSc Thesis at the International MSc Programme: Agricultural Science and Resource Management in the Tropics and Subtropics, at the Department of Cultural Landscape Ecology and Animal Ecology. Rheinische Friedrich-Wilhelms-Universität Bonn, Germany.

Wood B., 1975 - The Distribution of Races of the Yellow Wagtail Overwintering in Nigeria. Bulletin of the Nigerian Ornithologists' Society, 11: 19-26.

Wood B., 1976 - The biology of Yellow Wagtails Motacilla flava L. overwintering in Nigeria. University of Aberdeen, Aberdeen.

Wood B., 1978 - Weights of Yellow Wagtails wintering in Nigeria. Ringing \& Migration, 2: 20-26.

Wood B., 1979 - Changes in numbers of over-wintering Yellow Wagtails and their food supplies in a West-African Savanna. The Ibis, 121: 228-231.

Wood B., 1982 - The trans-Saharan spring migration of Yellow Wagtails. Zoological Society of London, 197: 267-283.

Wood B., 1992 - Yellow Wagtail Motacilla flava migration from West Africa to Europe: pointers towards a conservation strategy for migrants on passage. The Ibis, 134 (1): 66-76.

Wood B., 2002 - Yellow Wagtail Motacilla flava. In: The Migration Atlas: movements of the birds of Britain and Ireland. Wernham C. V., Toms M. P., Marchant J. H., Clark J. A., Siriwardena G. M. \& Baillie S. R. (eds.). T. \& A.D. Poyser, London: 369-372.

Xiong J., Thenkabail P. S., Tilton J. C., Gumma M. K., Teluguntla P., Oliphant A., Congalton R. G., Yadav K. \& Gorelick N., 2017 - Nominal 30-m Cropland Extent Map of Continental Africa by Integrating Pixel-Based and Object-Based Algorithms Using Sentinel-2 and Landsat-8 Data on Google Earth Engine. Remote Sensing, 9 (10): 1065.

Zarudny N. A., 1911 - Verzeichnis der Vögel Persiens. Journal für Ornithologie, Leipzig, 59: 185-241.

Ziervogel G., New M., van Garderen E. A., Midgley G., Taylor A., Hamann R., Stuart-Hill S., Myers J. \& Warburton M., 2014 - Climate change impacts and adaptation in South Africa. WIREs Climate Change, 5 (5): 605-620.

Zwarts L., Bijlsma R. G., van der Kamp J. \& Wymenga E., 2012 - Les ailes du Sahel. Zones humides et oiseaux migrateurs dans un environnement en mutation. KNNV Publishing.

\section{SUPPORTING INFORMATION / APPENDICE}

Additional Supporting Information may be found online for this article.

S1 - Wintering range of western yellow wagtail Motacilla flava in Africa and Europe in a historical perspective: detailed results / Areale di svernamento della Cutrettola Motacilla flava in Africa ed Europa in una prospettiva storica: risultati di dettaglio. 